\title{
Cephalopod associations and palaeoecology of the Cretaceous (Barremian- Cenomanian) succession of the Alpstein, northeastern Switzerland
}

Amane Tajika ${ }^{\mathrm{a}}$, Peter Kürsteiner ${ }^{\mathrm{b}}$, Antoine Pictet ${ }^{\mathrm{c}}$, Jens Lehmann ${ }^{\mathrm{d}}$, Karl Tschanz ${ }^{\mathrm{e}}$, Romain Jattiot $^{\mathrm{a}}$, Christian Klug ${ }^{\mathrm{a}}$

${ }^{a}$ Paläontologisches Institut und Museum, Universität Zürich, Karl Schmid-Strasse 4, CH-8006 Zürich, Switzerland

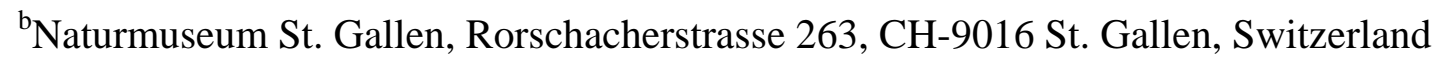

${ }^{\mathrm{c} I n s t i t u t e}$ of Earth Sciences, Bâtiment Géopolis, CH-1015 Lausanne, Switzerland

${ }^{\mathrm{d}}$ Fachbereich Geowissenschaften, Universität Bremen, Klagenfurter Strasse, 28359 Bremen, Germany

${ }^{\text {e }}$ Schneeglöggliweg 37, CH-8048 Zürich, Switzerland

\begin{abstract}
The Alpstein (cantons of Appenzell Ausserrhoden, Appenzell Innerrhoden and St. Gallen, northeastern Switzerland) has been of great interest for geologists over the last decades because of its excellent outcrops. However, there was no comprehensive overview over its Cretaceous fossil content. Here, we describe the cephalopod associations, which are moderately to highly diverse in some strata of the Alpstein. Furthermore, we document the regional palaeoecological changes that occurred during the radiation of heteromorph ammonites (ancyloceratids, scaphitids, turrilitids). To examine the palaeoecological changes,
\end{abstract}


we quantitatively determined the macrofossil content of 11 associations of Barremian to early Cenomanian age. Here, we document 6 species ( 3 genera) of nautilids and 77 species (45 genera) of ammonoids ( 29 of the species are recorded from Switzerland for the first time). Our palaeoecological analyses revealed the disappearance of nektoplanktonic forms after the late Barremian to the middle early Aptian in the course of the developoment of a shallow carbonate platform. The upper lower Aptian to middle Albian strata were eroded due to successive emersion phases and condensation processes. In the late Albian, the number of nektoplanktonic species surged again with some benthos, followed by the Cenomanian fauna, which is dominated by nektoplanktonic elements including ammonites, belemnites and nautilids with only very little benthos. These results correlate well with the regional sea level fluctuations.

\section{Keywords:}

ammonoids, nautilids, palaeoecology, taxonomy, Alpstein, Switzerland 


\section{Introduction}

The Ammonoidea is a well-known and highly diverse invertebrate group. Because of their high evolutionary rates, ammonoids are widely used as index fossils for about two centuries. Especially during the Jurassic and Cretaceous periods, ammonoids evolved a high diversity and morphological disparity (Page, 1996) combined with a commonly high intraspecific variability (e.g., De Baets et al., 2015; Tajika et al., 2015a). Remarkably, several taxa of three-dimensionally coiled ammonites evolved (heteromorphs; e.g., Cecca, 1997; Guex, 2006).

The Early Cretaceous was a time when large-scale plate tectonic movements and sea level changes (Haq, 2014) affected many ammonite habitats and their dispersal (Lehmann et al., 2015). Although a lot of research has been carried out on global sea-level changes (e.g., Mörner, 1981; Haq, 2014), which strongly influenced the dispersal of ammonoids, the number of regional datasets on alpha diversity and palaeoecology are low. Such studies are important because they contribute primary data to better understand the larger scale palaeoecological changes. In turn, this improved knowledge will increase our understanding of ammonoid autecology including aspects such as habitat and dispersal (e.g., Lukeneder, 2015).

Recently, Bush et al. (2007) introduced a novel approach using a three dimensional ecospace model. Comparison of palaeoecology between geological units both through geologic time and between regions or localities using this ecospace approach provides profound information on palaeoenvironmental changes through time and space.

In the Alpstein (cantons of Appenzell Innerrhoden and Ausserrhoden as well as St. Gallen, Switzerland), a large amount of work has been dedicated to sedimentology and structural geology for the past decades due to its excellently exposed Cretaceous deposits (Funk, 1969; Trümpy, 1980; Föllmi and Ouwehand, 1987; Ouwehand , 1987; Bodin et al., 2006; Sala et al., 
2014; Bonvallet, 2015; Wohlwend et al., 2015). The overview of lithofacies of the Alpstein is more or less summarized in Eugster et al. (1982). Although the mostly carbonatic deposits of the Cretaceous sequence (mainly Hauterivian to Cenomanian) contain a large number of macro- and microfossils, the regional biofacies has been studied only sporadically (for the Barremian see, e.g., Bodin et al., 2006). To fill this gap in knowledge, we have sampled eleven highly fossiliferous layers throughout the section in order to obtain semiquantitative data for alpha-diversity and other palaeoecological analyses.

In this study, we (1) document the available cephalopod taxa from the Alpstein (Barremian to Cenomanian), (2) semiquantitatively analyze palaeoecolgical changes from the Barremian to Cenomanian using macrofossils with a focus on ecospace utilisation through time and (3) discuss palaeoenvironmental factors and their changes.

\section{Locality and Geological Setting}

The Helvetic nappes, which belong to the northern Tethyan margin, extend from northeastern to southwestern Switzerland (Fig. 1; Bodin et al., 2006). The Alpstein massif (Fig. 2A) is located in northeastern Switzerland close to the border to Austria. In this region, the mountains Altmann (2436 m), Säntis (2502m), and Wildhuser Schafberg (2373 m) are situated. Being part of the Alpstein massif, they mainly consist of Cretaceous deposits of the "Säntis-Decke” (Säntis nappe), which is detached from the Jurassic succession by the Säntis Thrust (Sala et al., 2014). The investigated sedimentary sequence is as follows:

Tierwis Formation (uppermost Hauterivian to upper Barremian; Funk, 1969; Fig. 2B): The Tierwis Formation consists of two subunits, the Altmann Member and the Drusberg Member. The Altmann Member is composed of glauconite-rich marls and sandy limestones with abundant trace fossils that are occasionally pyritized. More condensed and phosphatic layers 
contain ammonites in a moderate to high abundance. The Drusberg Member lies above the Altmann Member, which is characterized by alternating marl and marly limestones. The latter also contains macrofauna, mostly benthos such as sea-urchins, bivalves and brachiopods, and rarely, necton such as ammonites.

Schrattenkalk Formation (upper Barremian to middle lower Aptian; Bollinger, 1988): The Schrattenkalk Formation is characterized by massive light grey limestones, which often contain many bioclasts. The sediments are from a shallow marine setting with abundant corals, sponges, algae, rudist bivalves and thick-shelled gastropods. The Schrattenkalk Formation is separated into two thick limestone layers (Lower and Upper Schrattenkalk Members) which are separated by the Rawil Member (Schenk, 1992; Föllmi et al., 2007). The Rawil Member, also formerly referred to as Lower Orbitolina Beds, starts with marly to sandy limestone beds which contain a rich benthic fauna of echinoids (Heteraster oblongus, Leptosalenia prestensis) and gastropods (Harpagodes pelagi) occasionally accompanied by wood remains. The Rawil Member lies in the middle of the Schrattenkalk Formation, starting with marly beds containing some wood remains. The marly Orbitolina Bed at the top of the Rawil Member marks the boundary between the Barremian and the lowermost Aptian (Bonvallet, 2015). These layers are rich in the foram Orbitolina as well as abundant sea-urchins (Heteraster olbongus, Leptosalenia prestensis). The boundary between the Upper Schrattenkalk Member and the Garschella Formation is marked by a layer with phosphorites that also contains fossils (e.g., belemnoid rostra; Föllmi, 1986, 1989a; Ouwehand 1987).

Garschella Formation (upper lower Aptian to lowermost Cenomanian; Föllmi and Ouwehand, 1987; Fig. 2D): In the Säntis area, a large part of the Aptian (Grünten, Brisi Members and lower part of the Selun Member) is missing due to erosion, non-deposition and condensation processes, resulting in a 13 m.y. hiatus. The Garschella Formation commences with dark greenish marls and marly limestones at the base (Sellamatt Beds; Föllmi and Ouwehand, 
1987), containing several fossiliferous, phosphatic conglomerates (Durschlägi and Wannenalp Beds; Föllmi and Ouwehand, 1987). These are overlain by glauconitic limestones with greyish limestone nodules in various sizes and amounts (Aubrig Beds; Föllmi and Ouwehand, 1987). This upper part of the Garschella Formation contains some indications for condensation such as fragmented ammonoids, phosphoritic internal moulds of fossils, and the fact that several ammonite zones are comprised in this thin sedimentary sequence. At the top of the Garschella Formation, glauconitic sandstones and nodular limestones are deposited, namely a condensation horizon called Kamm Bed that yields abundant and highly diverse ammonoid faunas.

Seewen Formation (lower Cenomanian-lower Santonian: Bolli, 1944; Föllmi, 1986; Fig. 2E): The Seewen Formation is characterized by light greyish pelagic limestone successions. At the base of the Seewen Formation, a bed with abundant ammonoids including large puzosiids (Fig. 2F), rare large turrilitids and normal-sized belemnoids can be found (exposed between Tierwis and the summit of Säntis).

\section{Material and Methods}

All the examined fossils are from the Alpstein, Switzerland (Figs. 1, 2). Most of them were collected by Peter Kürsteiner (St. Gallen) and Karl Tschanz (Zürich). Further specimens were kindly put at our disposal by Urs Oberli (St. Gallen) and Thomas Bolliger (Aathal). Our own fieldwork yielded further specimens. Most of these specimens will be deposited in the Naturmuseum St.Gallen with the numbers NMSG (Coll. followed by initials of the collector and a number). Abbreviations of the collector names are PK (Peter Kürsteiner), KT (Karl Tschanz), UO (Urs Oberli), TB (Thomas Bolliger) and AT (Amane Tajika). Further specimens were examined in the collections of the Federal institute of technology, Zurich 
(ETH ZH). These are stored in the ETH collections with the abbreviation ETHZ. Exact localities for collections of the ETH ZH and the Naturmuseum St.Gallen are often uncertain. Localities from which most of our specimens were collected are indicated in Fig. 1B.

For palaeoecological analyses, we sampled distinct fossiliferous layers between Tierwis and pillar 2 (second pillar of the cable car Schwägalp-Säntis "Stütze 2", below the summit of Säntis). Wherever possible, we tried to achieve a minimum sample size of 100 determinable specimens in order to obtain statistically representative data.

To quantitatively analyze the palaeoecological changes through geologic time, the method to compare ecospace utilization introduced by Bush et al. (2007) was employed. Accordingly, all fossils were classified based on the ecological parameters tiering, motility and feeding mechanism and were subsequently plotted into the three-dimensional ecospace. The assignment to an ecological guild was carried out following table 1 in Bush et al. (2007). Moreover, we added some taxa missing in Bush et al. (2007) in accordance with our fossils. The revised classification is summarized in Table 1. It should be noted that studies on ammonoid palaeoecology suggest different modes of life in ammonoids (planktonic or nektonic). Their mode of life probably changed throughout ontogeny (Ritterbush et al., 2014; Lukeneder, 2015; Moriya, 2015). Nevertheless, ammonoid habitat and mode of life is still not completely unravelled. In fact, many of the aspects cannot be fully tested. Thus, we considered ammonoids including heteromorphs to be part of the pelagic habitat with free and fast motility on the basis of the recent buoyancy reconstruction of ammonoids (Hoffman et al., 2015; Naglik et al., 2015; Tajika et al., 2015b). However, the ecological differences between various ammonoids would not affect the results of our palaeoecological study. Fossils are often poorly preserved and thus difficult or impossible to determine at the species level. Nevertheless, identifications allow assigning them to an ecospace unit sensu Bush et al. (2007). 
To investigate changes of palaeoecology from the Barremian to Cenomanian, macrofossils were counted in the field. We started counting fossils with a layer of the condensed phosphatic limestones of the Altmann Member (lower Barremian; mixing of N. pulchella and K. compressissima Zones). A total of 156 fossils were counted and assigned to modes of life. Due to the lack of fossiliferous layers in the upper part of the Tierwis Formation (Drusberg Member), only fossils from above the mentioned layer have been counted for the palaeoecological analysis.

The Schrattenkalk Formation contains mostly bioclastic shallow water limestones in its upper part. We counted fossils from eight different bedding planes (S1-S8; for their stratigraphic position see Fig. 3). Fossils were counted within $4.0 \mathrm{~m}^{2}(\mathrm{~S} 1), 0.50 \mathrm{~m}^{2}(\mathrm{~S} 2), 0.040 \mathrm{~m}^{2}$ (S3), $0.048 \mathrm{~m}^{2}$ (S4), $22.50 \mathrm{~m}^{2}$ (S5), $22.50 \mathrm{~m}^{2}$ (S6), $4.0 \mathrm{~m}^{2}$ (S7) and $0.024 \mathrm{~m}^{2}$ (S8). The numbers of determined fossils that could be assigned to a mode of life are 88 (S1), 207 (S2), 210 (S3), 322 (S4), 96 (S5), 92 (S6), 45 (S7) and 80 (S8).

The Garschella Formation contains some phosphatic and condensed layers, which are represented in the Twariberg Niederi, Sellamatt, Wannenalp, Aubrig, and Kamm Bed. We focused on two marly limestone layers (Wannenalp Bed), which contain the late Albian Hysteroceras binum, H. bucklandi, $H$. crassicostatum, H. orbignyi, $H$. varicosum, and Mortoniceras inflatum. It should be noted that the fauna from the examined marly limestone layers may not represent a single environment in time, considering that the above-mentioned ammonoids sometimes co-occur due to condensation and reworking (e.g., Kidwell and Bosence, 1991). Nevertheless, the faunal mixing (time averaging) is low enough to demonstrate a distinct change in palaeonenvironment from shallow water organisms (dominated by rudists, corals, sponges and algae) to deeper water (dominated by ammonoids, belemnoids and nautilids). Due to the 13 my hiatus at the top of the Urgonian platform and faunal mixing, fine ecological details of the ecological transition from a very shallow, photic 
zone carbonate platform environment to a deeper, pelagic environment dominated by nektoplanktonic forms cannot be extracted. However, the major change could be documented from the differences in faunal assemblages from the early Aptian to late Albian, because we did not find the shallow water indicators such as corals, sponges and photosynthetic organisms being mixed into the younger fauna. A total of 251 fossils from the Garschella Formation was plotted into ecospace (Wannenalp and Aubrig Beds). The Kamm Bed also shows condensation documented in the co-occurrence of the latest Albian Stoliczkaiella with the Early Cenomanian Mantelliceras saxbii. A total of 240 specimens from the Kamm Bed were plotted into the ecospace graph. At the base of the Seewen Formation (lower Cenomanian), 98 specimens were counted on a widely exposed bedding plane.

The morphologic terms for the description of cephalopods were adopted from Arkell (1957) and Korn (2010). Further details are given in Klug et al. (2015). Abbreviations of the measurements of conchs are dm (conch diameter), ww (whorl width), wh (whorl height) and uw (umbilical width).

\section{Results}

\subsection{Cretaceous cephalopod associations of the Alpstein}

From all stratigraphic levels, a total of 6 species ( 3 genera) of nautilids and 77 species (45 genera) of ammonoids were documented (see the systematic palaeontology section). The Tierwis Formation (upper Hauterivian to upper Barremian) yielded 3 species (2 genera) of nautilids and 16 species (12 genera) of ammonoids; we counted 4 species ( 2 genera) of nautilids and 27 species (17 genera) from the Garschella Formation (except the Kamm Bed); the Kamm Bed alone yielded 3 species (1 genus) of nautilids and 42 species ( 25 genera) of ammonoids. The Barremian ammonite associations of the Alpstein are dominated by weakly 
ornamented forms such as Barremites, followed by strongly ornamented Holcodiscidae and heteromorphic forms. The late Albian ammonite associations are dominated by heteromorphic forms, while the early Cenomanian ammonoid fauna contains many large puzosiids with smooth conchs and moderately sized, strongly ornamented acanthoceratids.

Here, we document 29 species, which we report from Switzerland for the first time: Cymatoceras subradiatum (d'Orbigny, 1850), Eutrephoceras sublaevigatum (d'Orbigny, 1850), Torcapella davydovi (Trautschold, 1886), T. falcata Busnardo, 1970, Puzosia lata Seitz, 1931, Hysteroceras binum (Sowerby, 1815), H. crassicostatum (Jayet, 1929), H. varicosum (Sowerby, 1824), Mortoniceras cf. inflatum (Sowerby, 1818), Dipoloceras cf. pseudaon Spath 1931, Stoliczkaiella (Lamnayella) juigneti Wright and Kennedy, 1978, S. (L.) crotaloides (Stoliczka, 1864), Astieridiscus morleti (Kilian, 1889), Parasaynoceras tzankovi (Avram, 1995), Tetragonites timotheanus timotheanus Pictet, 1847, Kossmatella muhlenbecki (Fallot, 1885), Douvilleiceras sp., Hamulinites sp., Sciponoceras roto Cieśliński, 1959, Hamites simplex d'Orbigny, 1842, Ham. cf. maximus Sowerby, 1814, Ham. cf. similis Casey, 1961, Ostlingoceras costulatum (Pervinquiére, 1910), Hypoturrilites $\mathrm{cf}$. sharpei Wright and Kennedy, 1996, Hyp. gravesianus (d'Orbigny, 1842), Neostlingoceras carcitanense (Matheron, 1842), Eoscaphites subcircularis (Spath, 1937), Hyphoplites curvatus curvatus Mantell, 1822, Gorethophylloceras subalpinum (d'Orbigny, 1841).

\subsection{Palaeoecological changes from the Barremian to Cenomanian}

Fossil abundances and ecological classification based on Bush et al. (2007) are summarized in Fig. 4 and Table 2. The results illustrate distinct faunal turnovers from the Barremian through to the early Cenomanian. Nektoplanktonic organisms dominate the faunules of the Barremian, late Albian and early Cenomanian, while faunules exclusively with benthos are from the late Barremian throughout to the early Aptian. 


\section{Systematic palaeontology}

Order Nautilida Gray, 1821

Family Cymatoceratidae Spath, 1927

Genus Cymatoceras Hyatt, 1884

Cymatoceras cf. neocomiense (d'Orbigny, 1840)

Fig. 5E, F.

Synonymy: See Delanoy et al. (2012).

Lectotype: Nautilus neocomiensis d'Orbigny, 1840; p. 74, 5, 91, 95, 97, pl.11, fig 1-3.

Material: 1 deformed and eroded phragmocone fragment (NMSG Coll. PK. 7.B.06.01). A

slightly compressed phragmocone with one completely eroded side (NMSG Coll. PK.

5A.13.05).

Locality and horizon: Oberrieter Chienberg, Garschella Formation, Albian (NMSG Coll. PK.

7.B.06.01); Wis (SW Alp Rohr); Altmann Member, uppermost Hauterivian-upper lower

Barremian (NMSG Coll. PK. 5A.13.05).

Description: NMSG (Coll. PK. 7.B.06.01) is deformed with a maximum conch diameter of $170 \mathrm{~mm}$. The conch shape is involute $(\mathrm{uw} / \mathrm{dm}=0.11)$ and pachyconic $(\mathrm{ww} / \mathrm{dm}=0.30)$. The whorl section is much higher than wide $(\mathrm{ww} / \mathrm{wh}=0.61)$. Conspicuous falcate ribs are present without bifurcation. The number of ribs per half a whorl is 35 .

Discussion: This species is one of the most compressed species of Cymatoceras. $C$.

bifurcatum is similarly compressed, but it differs in having bifurcating ribs. According to Pictet (1848), C. neckerianum is similar to this species but less compressed.

Occurrence: Lower Cretaceous (Hauterivian-Albian); Spain, France, Germany, Switzerland, Austria, Hungary, Romania, Bulgaria, Ukraine, Turkey, Iran, Turkmenistan, Algeria, Japan. 
1840. Nautilus laevigatus, d'Orbigny. d'Orbigny, p.84-86, 94, 95, 96, 97, pl.17, figs.1-4.

1960. Eutrephoceras sublaevigatum (d'Orbigny) 1850. Wiedmann, p.165, pl.19, fig.O, pl.20, fig.A, pl.23, fig.L.

1979. Eutrephoceras sublaevigatum (d’Orbigny). Wiedmann and Schneider, p.652, pl.2, figs.2, 3, text-fig.4A.

2006. Eutrephoceras sublaevigatum d'Orbigny, 1840. Gauthier, p.20, pl.2, figs. 5a, b, 6.

Holotype: Nautilus radiatus, Sowerby, 1822; p. 78, pl.356.

Material: An internal mould of a phragmocone and a partial body chamber with remains of the ventral ornamentation (NMSG Coll. PK. 5A.06.02, NMSG Coll. PK. 5A.05.02. A well preserved internal mould with some shell remains (ETHZ 10435).

Locality and horizon: Altmann-Sattel Nordost-Seite I (NMSG Coll. PK. 5A.06.02), AltmannSattel, Südwest-Seite I (NMSG Coll. PK. 5A.05.02), Altmann Member, late lower Barremian ; Toggenburg, ?Altmann Member, uppermost Hauterivian-upper lower Barremian (ETHZ 10435).

Description: ETHZ 10435 has a maximum diameter of $104 \mathrm{~mm}$. The conch is thickly discoidal (ww/dm=0.57) and involute (uw/dm=0.12). The whorl section is slightly wider than high $(w w / w h=1.07)$. There are $4-5$ ribs between two septa on the ventral part. The septa are almost straight or slightly curved, projecting adperturally.

Discussion: This species is close to C. neckerianum. Kummel (1956) illustrated whorl sections of Cymatoceras in which $C$. subradiatum has a slightly larger umbilicus than $C$. neckerianum and C. neocomiense is more compressed.

Occurrence: Lower-Upper Cretaceous (Cenomanian); Spain, England, France, Ukraine, Georgia.

Genus Eucymatoceras Spath, 1927 
Eucymatoceras plicatum (Fitton, 1835)

Fig. 5A, B, M, N.

Synonymy: See Delanoy et al. (2012).

Holotype: Nautilus plicatus Fitton, 1835; p. 129, text-fig.

Material: Three large internal moulds of phragmocones with shell remains (NMSG Coll. PK. 5.B.03.19, ETHZ 10434, NMSG Coll. AT. 1).

Locality and horizon: Chobel, Gartenalp, Drusberg Member, Barremian (NMSG Coll. PK.

5.B.03.19); Kohlbett below the Seealpsee, Säntis, ?Barremian (ETHZ 10434); Lochtem-

Wagenlücke (NMSG Coll. Tajika 1), Altmann Member, uppermost Hauterivian-upper lower Barremian.

Description: NMSG (Coll. PK. 5.B.03.19) with a maximum diameter of $149 \mathrm{~mm}$. The conch is thinly globular (ww/dm=0.89) with rounded whorl section and the umbilicus is almost closed $(\mathrm{uw} / \mathrm{dm}=0.07)$. The whorl section is wider than high $(\mathrm{ww} / \mathrm{wh}=2.0)$. Approximately 30 conspicuous zig zag ribs, which are characteristic for this genus, can be counted per half whorl.

Discussion: The above mentioned characters (the globose conch shape, the zig-zag ribs and the angular part of the zig-zag ribs lying on the venter) corresponds to the illustration (pl. 10, Nautilus Requienianum) in d'Orbigny (1840) which is a synonym of C. plicatum.

Occurrence: Lower Cretaceous (Albian); England, Spain, France, Germany, Switzerland, Austria, Romania, Bulgaria, Ukraine, Georgia.

Genus Eutrephoceras Hyatt, 1894

Eutrephoceras montmollini (Pictet and Campiche, 1859)

Fig. 6A-D.

Synonymy: No report with comprehensive description has been published since the original description of Pictet and Campiche (1859). 
Syntypes: Nautilus montmollini Pictet and Campiche, 1859; p. 147, pl. 18, figs. 4-6.

Material: Internal moulds of phragmocones with some erosion (NMSG Coll. PK. 7.C.02.11, NMSG Coll. PK. 7.C.13.23, NMSG Coll. PK. 7.C.02.19, NMSG Coll. PK. 7.C.02.40, NMSG Coll. PK. 7.B.25.36).

Locality and horizon: Stütze 2 Säntisbahn S (NMSG Coll. PK. 7.C.02.11, 7.C.02.19, 7.C.02.40), Säntis, Gasthaus-Hang (NMSG Coll. PK. 7.C.13.23), Kamm Bed, uppermost Albian-lowermost Cenomanian; Bergli, Sennwald, Garschella Formation, Albian (NMSG Coll. PK. 7.B.25.36).

Description: The specimen NMSG (Coll. PK. 7.C.02.11; $\mathrm{dm}=38 \mathrm{~mm}$ ), is involute $(\mathrm{uw} / \mathrm{dm}=0.03)$ and thinly pachyconic $(\mathrm{ww} / \mathrm{dm}=0.68)$ with weakly depressed and semicircular whorl cross sectioin. The whorl section is slightly higher than wide $(\mathrm{ww} / \mathrm{wh}=1.13$; $\mathrm{wh} / \mathrm{dm}=0.64)$. The whorls overlap strongly. There are 8 suture lines within half a whorl with broadly rounded median and dorsal saddles.

Discussion: This species has a very small umbilicus. The specimens have dimensions similar to those of the syntypes measured in Pictet and Campiche (1859). Over the last decades, taxonomic and systematic studies on Cretaceous nautilids have been conducted much less frequently than on Cretaceous ammonoids. A comprehensive revision is required to solve the current taxonomic confusion.

Occurrence: Lower Cretaceous (Barremian-Albian); Germany, Switzerland, Russia.

Eutrephoceras perlatum (Morton, 1834)

Figs. 5I, J, 6G, H.

1834. Nautilus perlatus Morton, p.33, pl.13, fig.4.

1852. Nautilus Dekayi. Giebel, pp.150/1.

1960. Eutrephoceras dekayi (Morton). Wiedmann, p.151, 155/6, pl.17, figs.A-C, pl.23, fig.B. 
1962. Eutrephoceras dekayi (Morton). Miller and Garner, pp.102-111, pl.65, figs.1-6, pl.66, figs.1,2, pl.67, figs.1-9

Holotype: Nautilus perlatus Morton 1834; p. 33, pl.13, fig.4.

Material: Internal moulds of phragmocones (ETHZ 10430, NMSG Coll. KT. HW-A-0038, NMSG Coll. PK. 7.C.12.07, 7.B.37.08, 7.C.15.08, 7.C.15.30), internal moulds of phragmocones with partial body chamber (NMSG Coll. PK. 7.B.09.02, 7.C.18.01, 7.C.15.08) and a deformed specimen (NMSG Coll. PK.7.B.25.09).

Locality and horizon: ?St. Fähnern, Appenzell (ETHZ 10430), ?Albian; HinterwindenHornwald (Hinter Gräppelen) (NMSG Coll. KT. HW-A-0038), Ebenalp, Übergang gegen Gartenalp (NMSG Coll. PK. 7.C.12.07), Mutteli (NMSG Coll. PK.7.C.18.01), HinterwindenHornwald (Hinter Gräppelen; NMSG Coll. PK. 7.C.15.08, 7.C.15.30), Kamm Bed, uppermost Albian-lowermost Cenomanian; Chelen-Geren (SW Plona; NMSG Coll. PK. 7.B.37.08), Säntis, Gasthaus-Galerie and surrounding (NMSG Coll. PK. 7.B.09.02), Bergli, Sennwald (NMSG Coll. PK.7.B.25.09), Garschella Formation, Albian.

Description: NMSG (Coll. PK.7.C.18.01) is $31 \mathrm{~mm}$ in maximum diameter. The conch is involute $(\mathrm{uw} / \mathrm{dm}=0.10)$ and pachyconic $(\mathrm{ww} / \mathrm{dm}=0.73)$ with widely rounded whorl section. The whorl section is higher than wide $(\mathrm{ww} / \mathrm{wh}=1.39 ; \mathrm{wh} / \mathrm{dm}=0.53)$. The whorls overlap strongly. The suture line is slightly curved. There are 9 suture lines within half a whorl with very broad median and dorsal saddles.

Discussion: The specimens have conch parameters similar to those of the specimens illustrated on Plates 65-67 in Miller and Garner (1962). Our specimens also show similarities to the holotype in Morton (1834; pl. 13, fig. 4) in coiling and the falcoid suture lines. Occurrence: Lower-Upper Cretaceous; Germany, Poland, Sweden, Canada, USA (New Jersey, Texas). 
Fig. 5C, D, K, L.

Synonymy: See the revision by Gauthier (2006).

Syntypes: Nautilus laevigatus d'Orbigny, 1850; p. 84-86, 94,-97, pl. 17, figs. 1-4.

Material: Internal moulds of phragmocones (NMSG Coll. KT. HW-A-0039-1, NMSG Coll.

PK. 7.C.02.41, 7.C.09.02, 7.B.25.33). Internal mould of a phragmocone with a partial body chamber (NMSG Coll. PK. 7.C.12.02).

Locality and horizon: Hinterwinden-Hornwald (Hinter Gräppelen) (NMSG Coll. KT. HW-A0039-1), Stütze 2 Säntisbahn S (NMSG Coll. PK. 7.C.02.41), Zwinglipass Nordost (NMSG

Coll. PK. 7.C.09.02), Ebenalp, Übergang gegen Gartenalp (NMSG Coll. PK. 7.C.12.02), Kamm Bed, uppermost Albian-lowermost Cenomanian; Bergli, Sennwald, Garschella Formation, Albian (NMSG Coll. PK. 7.B.25.33).

Description: NMSG (Coll. PK. 7.B.25.09) measures $33 \mathrm{~mm}$ diameter. The conch is involute $(\mathrm{uw} / \mathrm{dm}=0.06)$ and thickly pachyconic $(\mathrm{ww} / \mathrm{dm}=0.78 ; \mathrm{wh} / \mathrm{dm}=0.64)$ with rounded whorl section. The suture line is slightly curved. The whorls overlap moderately to strongly. There are 9 suture lines with broadly rounded median and dorsal saddle.

Remarks: This species has a small umbilicus and a rounded aperture. The specimens have parameters similar to those of the syntype illustrated on Plate 17 in d'Orbigny (1840). Occurrence: Lower-Upper Cretaceous (Albian-Santonian); England, Germany, Italy, Czech Republic, Poland, Bulgaria, Libya, India.

Order Ammonoidea Zittel, 1884

Family Barremitidae Breskovski, 1977

Genus Barremites Killian, 1913

Barremites cf. difficilis (d'Orbigny, 1841)

Fig. 6E, F, I-L, O, P, V, W. 
Synonymy: See Klein and Vašíček (2011); the species was also referred to by Lukeneder (2012; without description).

Lectotype: Ammonites difficilis d'Orbigny, 1841; 9. 135, pl. 41, fig. 3, 4.

Material: 33 internal moulds (NMSG Coll. PK. 5.A.05.05, 5.A.05.25, 5.A.05.46, 5.A.05.48, 5.A.05.65 to 5.A.05.80, 5.A.10.03, 5.A.06.01, 5.A.10.02, 5.A.10.03, 5.A.13.04, 5.A.17.03, 5.A.17.04, NMSG Coll. KT. AS-W-0001, AS-W-0005, AS-W-0022, AS-W-0024, AS-W0025, NMSG Coll. UO. 001).

Locality and horizon: Altmann-Sattel, Südwest-Seite I (NMSG Coll. PK. 5.A.05.05, 5.A.05.25, 5.A.05.46, 5.A.05.48, 5.A.05.65 to 5.A.05.80,, NMSG COLL. KT. AS-W-0001, AS-W-0005, AS-W-0025), Altmann-Sattel Nordost-Seite I (NMSG Coll. PK. 5.A.06.01), Litten, Chreialp (NMSG Coll. PK. 5.A.10.02, 5.A.10.03), Wis (SW Alp Rohr; NMSG Coll. PK. 5.A.13.04), Chobel, Frümsner Berg (NMSG Coll. PK. 5.A.17.03, 5.A.17.04), Spitzbergli (NMSG Coll. UO. 001), Altmann Member, uppermost Hauterivian-upper lower Barremian. Description: NMSG (Coll. PK. 5.A.05.73) is an internal mould with some shell remains, measuring $41 \mathrm{~mm}$ in diameter. The conch is extremely discoidal $(\mathrm{ww} / \mathrm{dm}=0.20)$ and involute $(\mathrm{uw} / \mathrm{dm}=0.15)$. The whorl section is much higher than wide $(\mathrm{ww} / \mathrm{wh}=0.38)$ with a moderately flattened ventral part. Ribs appear to be intercalated by weak lirae. The largest specimens are NMSG (Coll. PK. 5.A.06.01) and NMSG (Coll. PK. 5.A.10.02), measuring $220 \mathrm{~mm}$ and $111 \mathrm{~mm}$ in conch diameter, respectively. The other specimens range from $35 \mathrm{~mm}$ to $76 \mathrm{~mm}$. All the specimens with nearly complete conchs are extremely discoidal $(\mathrm{ww} / \mathrm{wh}=$ $0.19-0.29)$ and, in most specimens, involute $(\mathrm{uw} / \mathrm{dm}=0.10-0.15)$ while others are subinvolute (uw/dm = 0.16-0.25; NMSG (Coll. KT. AS-W-0005, AS-W-0022), NMSG (Coll. PK. 5.A.06.01, 5.A.05.67, 5.A.13.04).The whorl section is oval to triangular and much higher than wide $(\mathrm{ww} / \mathrm{wh}=0.38-0.54)$ with the maximum width in the mid flank. Ribs and constrictions are hardly discernible in all specimens except NMSG (Coll. PK. 5.A.05.75), in which 5 ribs are present per half whorl. 
Discussion: Although all the specimens show similar characteristics (very compressed and narrow umbilicus), the ornamentation is poorly preserved, hampering the species-level determination.

Occurrence: Lower Cretaceous (Barremian); France, Switzerland, Italy, Austria, Czech Republic, Romania, Bulgaria, Russia, Egypt, Japan.

Genus Torcapella Busnardo, 1970

Torcapella davydovi (Trautschold, 1886)

Fig. 7A, B.

Synonymy: See Klein and Vašíček (2011).

Type: Ammonites davydovi Trautschold, 1886; p. 141.

Material: 1 eroded conch (NMSG Coll. PK. 5.A.17.01).

Locality and horizon: Chobel, Frümsner Berg, Altmann Member, uppermost Hauterivianupper lower Barremian.

Description: NMSG (Coll. PK. 5.A.17.01) is a slightly deformed specimen, measuring 132 $\mathrm{mm}$ in diameter. The conch is extremely discoidal $(\mathrm{ww} / \mathrm{dm}=0.30)$ and subinvolute $(\mathrm{uw} / \mathrm{dm}=$ 0.22). The whorl section is oval and compressed $(\mathrm{ww} / \mathrm{wh}=0.72)$ with maximum whorl width in the mid flank. There are 18 ribs per quarter whorl with falcoid shape.

Discussion: See Busnardo (1970).

Occurrence: Lower Cretaceous (lower Barremian, Kotetishvilia compressissima Zone);

England, France, Austria, Poland, Bulgaria, Madagascar.

Torcapella falcata Busnardo, 1970

Fig. 6X, Y.

Synonymy: See Klein and Vašíček (2011).

Holotype: Torcapella falcata Busnardo, 1970; p. 112, pl. 2, fig. 2, text-figs. 34, 35. 
Material: 1 eroded conch (NMSG Coll. PK. 5.A.05.87).

Locality and horizon: Altmann-Sattel, Südwest-Seite I, Altmann Member, uppermost Hauterivian-upper lower Barremian.

Description: NMSG (Coll. PK. 5.A.05.87) is a slightly weathered specimen, measuring 147 $\mathrm{mm}$ in diameter. The conch is extremely thinly discoidal $(\mathrm{ww} / \mathrm{dm}=0.28)$ and involute $(\mathrm{uw} / \mathrm{dm}=0.15)$. The whorl section is triangular and very compressed $(\mathrm{ww} / \mathrm{wh}=0.57)$ with the maximum whorl width in the mid flank. There are 18 falcoid ribs per quarter whorl. Discussions: See Busnardo (1970).

Occurrence: Lower Cretaceous (lower Barremian; K. compressissima Zone); England, France, Austria, Poland, Bulgaria, Madagascar.

Torcapella cf. fabrei (Torcapel, 1884)

Fig. 6M, N.

Synonymy: See Klein and Vašíček (2011).

?Topotype: Ammonites fabrei Torcapel, 1884; p. 1. pl. V.

Material: 1 conch (NMSG Coll. PK. 5.A.05.30).

Localitiy: Altmann-Sattel, Südwest-Seite I, the Altmann Member, uppermost Hauterivianupper lower Barremian.

Description: NMSG (Coll. PK. 5.A.05.30) is a weathered specimen, measuring $112 \mathrm{~mm}$ in maximum diameter. The conch is extremely discoidal $(\mathrm{ww} / \mathrm{dm}=0.29)$ and subinvolute $(\mathrm{uw} / \mathrm{dm}=0.33)$. The whorl section is oval and compressed $(\mathrm{ww} / \mathrm{wh}=0.64)$ with maximum whorl width on the mid flank. The straight to slightly falcoid ribs, which are apparently not bifurcating, are poorly visible.

Discussion: See Busnardo (1970).

Occurrence: Lower Cretaceous (lower Barremian, N. pulchella to C. darsi Zone); England, France, Austria, Poland, Bulgaria, Madagascar. 


\section{Torcapella sp.}

Fig. 6Q.

Material: 1 heavily eroded conch (NMSG Coll. PK. 5.A.05.29) and 2 conch fragments (NMSG Coll. KT. AS-W-0003, AS-W-0027).

Locality and horizon: Altmann-Sattel, Südwest-Seite I (NMSG Coll. PK. 5.A.05.29, NMSG Coll. KT. AS-W-0003, AS-W-0027), Altmann Member, uppermost Hauterivian-upper lower Barremian.

Description: NMSG (Coll. PK. 5.A.05.29) measures $112 \mathrm{~mm}$ in diameter. The conch is extremely discoidal $(\mathrm{ww} / \mathrm{dm}=0.26)$ and subinvolute $(\mathrm{uw} / \mathrm{dm}=0.21)$. The whorl section is oval and very compressed $(\mathrm{ww} / \mathrm{wh}=0.58)$. Ribs are present, most of which are hardly visible. Discussion: Most ribs, which are one of the most important diagnostic characters, are not well preserved, thus hampering species assignment.

Stratigraphic occurrence: Lower Cretaceous (lower Barremian, K. compressissima Zone; for the genus).

Family Desmoceratidae Zittel, 1895

Subfamily Puzosiinae Spath, 1922

Genus Puzosia (Puzosia) Bayle, 1878

Puzosia (Puzosia) lata Seitz, 1931

Figs. 6AF, AG, 7J, K.

Synonymy: See Klein and Vašíček (2011).

Holotype: Ammonites planulatus Quenstedt, 1847; p. 403, pl. 17, figs. 13a, b.

Material: 4 fragments (NMSG Coll. PK. 7.B.20.35, 7.B.20.74, 7.C.15.13, 7.C.23.20). 
Locality and horizon: In Ränken, Plona (NMSG Coll. PK. 7.C.23.20), Schlatt (above Rüthi SG; NMSG Coll. PK. 7.B.20.35, 7.B.20.74), Garschella Formation, Albian; HinterwindenHornwald (Hinter Gräppelen; NMSG Coll. PK. 7.C.15.13), Kamm Bed, latest AlbianCenomanian.

Description: NMSG (Coll. PK. 7.C.15.13) is a slightly deformed specimen, measuring $72 \mathrm{~mm}$ in diameter. The conch is subevolute $(\mathrm{uw} / \mathrm{dm}=0.36)$ and thinly discoidal $(\mathrm{ww} / \mathrm{dm}=0.36)$. The whorl width exceeds whorl height $(\mathrm{ww} / \mathrm{wh}=1.08)$. There are four nearly straight to slightly sinuous constrictions per whorl. NMSG (Coll. PK. 7.B.20.74) measures $19 \mathrm{~mm}$ in diameter. Its conch is subevolute $(\mathrm{uw} / \mathrm{dm}=0.33)$ and thinly discoidal $(\mathrm{ww} / \mathrm{dm}=0.47)$. The whorl width exceeds whorl height $(\mathrm{ww} / \mathrm{wh}=1.13)$. There are five very slightly sigmoidally bent constrictions per whorl.

Discussion: This species is mainly characterized by its depressed and rounded whorl section with the maximum thickness at the mid-flank.

Occurrence: Lower Cretaceous (middle-upper Albian); France, Italy (Sardinia), Austria, Madagascar, Venezuela.

Puzosia (Puzosia) mayoriana (d'Orbigny, 1841)

Fig. 7E-H, L-O.

Synonymy: See Kennedy and Klinger (2014).

Lectotype: Ammonites planulatus Sowerby 1827; p. 597, pl. 570, fig. 5.

Material: 13 fragments of phragmocones (NMSG Coll. PK. 7.B.20.19, 7.B.20.46, 7.B.23.05, 7.B.23.13, 7.B.23.14, 7.B.26.19, 7.B.37.09, 7.B.38.02, 7.C.07.01, 7.C.07.04, 7.C.13.12, 7.C.13.40, 7.C.15.22).

Locality and horizon: Chelen-Geren (SW Plona; NMSG Coll. PK. 7.B.37.09), In Ränken, Plona (NMSG Coll. PK. 7.B.23.05, 7.B.23.13, 7.B.23.14), Schlatt (above Rüthi SG; NMSG Coll. PK. 7.B.20.46, 7.B.20.19), Unter-Hard, Rüthi SG (NMSG Coll. PK. 7.B.38.02, Stofel, 
Lenziwis (NMSG Coll. PK. 7.B.26.19, Garschella Formation, Albian; Säntis, Gasthaus-Hang (NMSG Coll. PK. 7.C.13.40), Tal-Wänneli (NE Neuenalpspitz; NMSG Coll. PK. 7.C.07.01), Säntis, Gasthaus-Hang (NMSG Coll. PK. 7.C.13.12), Hinterwinden-Hornwald (Hinter Gräppelen; NMSG Coll. PK. 7.C.15.13, 7.C.15.22), Kamm Bed, uppermost Albianlowermost Cenomanian.

Description: NMSG (Coll. PK. 7.B.23.14) measures $28 \mathrm{~mm}$ in maximum diameter. The conch is sub-involute $(\mathrm{um} / \mathrm{dm}=0.26)$ and extremely discoidal $(\mathrm{ww} / \mathrm{dm}=0.34)$. The whorl section is much higher than wide $(\mathrm{ww} / \mathrm{wh}=0.80)$. There are four constrictions per whorl. NMSG (Coll. PK. 7.C.13.12) has a maximum diameter of $50 \mathrm{~mm}$. The conch is subinvolute $(\mathrm{um} / \mathrm{dm}=0.27)$ and extremely discoidal $(\mathrm{ww} / \mathrm{dm}=0.30)$. The whorl section is much higher than wide $(\mathrm{ww} / \mathrm{wh}=0.71)$. In our specimens, five constrictions were counted per whorl. NMSG (Coll. PK. 7.B.20.46) is a slightly deformed specimen with a diameter of $33 \mathrm{~mm}$. The conch is subevolute $(\mathrm{uw} / \mathrm{dm}=0.33)$ and extremely discoidal $(\mathrm{ww} / \mathrm{dm}=0.33)$. The whorl section is slightly higher than wide $(\mathrm{ww} / \mathrm{wh}=0.85)$. This specimen displays five sinuous constrictions per whorl.

Discussion: See Wright and Kennedy (1984) as well as Cooper and Kennedy (1987).

Occurrence: Lower-Upper Cretaceous (upper Albian-late Cenomanian); western EuropeIran, India, South Africa (KwaZulu-Natal), USA (off Florida), Japan.

Puzosia (Puzosia) cf. provincialis (Parona and Bonarelli, 1897)

Figs. 6AD, AE, 7V, W.

Synonymy: See Kennedy and Klinger (2014).

Holotype: Desmoceras provincialis Parona and Bonarelli, 1897; p. 81, pl. XI (II), figs. 4a. Material: 8 fragments of phragmocones (NMSG Coll. PK. 7.B.20.02, 7.B.20.30, 7.B.20.73, 7.B.25.29, 7.B.26.01, 7.B.26.20, 7.B.37.33, 7.B.38.04). 
Locality and horizon: Stofel, Lenziwis (NMSG Coll. PK. 7.B.26.01, 7.B.26.20), Chelen-

Geren (SW Plona; NMSG Coll. PK. 7.B.37.33), Unter-Hard, Rüthi SG (NMSG Coll. PK.

7.B.38.04), Bergli, Sennwald (NMSG Coll. PK. 7.B.25.29), Schlatt (above Rüthi SG; NMSG

Coll. PK. 7.B.20.30, 7.B.20.73), Garschella Formation, Albian.

Description: NMSG (Coll. PK. 7.B.20.73) is a small specimen with a diameter of $24 \mathrm{~mm}$. The conch is subinvolute $(\mathrm{uw} / \mathrm{dm}=0.26)$ and thinly discoidal $(\mathrm{ww} / \mathrm{dm}=0.44)$. The width and height of the whorl section is almost equal $(\mathrm{ww} / \mathrm{wh}=0.94)$. There are 5 or more nearly straight constrictions per whorl. NMSG (Coll. PK. 7.B.26.01) is a well preserved internal mould with a maximum diameter of $42 \mathrm{~mm}$. The conch is sub-evolute $(\mathrm{uw} / \mathrm{dm}=0.36)$ and thinly discoidal $(\mathrm{ww} / \mathrm{dm}=0.36)$. Width and height of the whorl section are almost equal $(\mathrm{ww} / \mathrm{wh}=1.00)$. There are six sinuous constrictions per whorl.

Discussion: The holotype of Puzosia (Puzosia) cf. provincialis measures $22.5 \mathrm{~mm}$ with a subevolute $(\mathrm{uw} / \mathrm{dm}=0.40)$ and thinly discoidal conch $(\mathrm{ww} / \mathrm{dm}=0.44)$. The whorl section is as high as wide $(\mathrm{ww} / \mathrm{wh}=1.00)$. Our specimens agree more or less with the conch parameters of this rather than with those of other species. For details, see Kennedy and Klinger (2014) Occurrence: Lower-Upper Cretaceous (middle-upper Albian); Spain (Mallorca), Italy (Sadinia), Switzerland, Romania, Bulgaria, Angola, possibly Egypt, Madagascar, Venezuela, Japan.

Puzosia (Puzosia) quenstedti quenstedti (Parona and Bonarelli, 1897)

Fig. 6Z-AC.

Synonymy: See Kennedy and Fatmi (2014).

Holotype: Desmoceras Quenstedti Parona and Bonarelli, 1897; p. 81, pl. XI (II), figs. 3a, b. Material: 9 fragments of phragmocones (NMSG Coll. PK. 7.B.20.42, 7.B.23.34, 7.B.23.22, 7.B.26.14, 7.B.25.19, 7.B.25.25, 7B.37.27, 7.C.02.38, 7.C.07.10). 
Locality and horizon: Chelen-Geren (SW Plona; NMSG Coll. PK. 7B.37.27), Bergli, Sennwald (NMSG Coll. PK. 7.B.25.19, 7.B.25.25), Schlatt (above Rüthi SG; NMSG Coll. PK. 7.B.20.42), In Ränken, Plona (NMSG Coll. PK. 7.B.23.34, 7.B.23.22), Garschella Formation, Albian; Tal-Wänneli (NE Neuenalpspitz; NMSG Coll. PK. 7.C.07.10), Kamm Bed, latest Albian-Cenomanian; unknown (Stütze 2 Säntisbahn S).

Description: NMSG (Coll. PK. 7.B.23.14) measures $36 \mathrm{~mm}$ in diameter. The conch is subinvolute $(\mathrm{uw} / \mathrm{dm}=0.29)$ and thinly discoidal $(\mathrm{ww} / \mathrm{dm}=0.35)$. The whorl section is higher than wide $(\mathrm{ww} / \mathrm{wh}=0.79)$. There are five slightly sinuous constrictions per whorl.

Discussion: According to Marcinowski and Wiedmann (1990), who divided the spcecies into five subspecies, Puzosia quenstedti quenstedti is characterized by its whorl section (slightly higher than wide) and a more pronounced ribbing of the external whorls. However, as Kennedy and Klinger (2014) mentioned, there have been various interpretations of this species. Thus, further studies on this group are necessary.

Occurrence: Lower-Upper Cretaceous (upper Aptian-lower Cenomanian); France, Italy (Sardinia), Austria, Pakistan, Madagascar, South Africa (KwaZulu-Natal), Venezuela.

Puzosiinae indet.

Fig. 7C, D.

Material: 1 conch (ETHZ 10437).

Locality and horizon: Locality, unknown, Altmann Member, uppermost Hauterivian-upper lower Barremian.

Description: ETHZ 10437 is an internal mould with a diameter of $174 \mathrm{~mm}$. The conch is subinvolute $(\mathrm{uw} / \mathrm{dm}=0.33)$ and moderately discoidal $(\mathrm{ww} / \mathrm{dm}=0.43)$. Width and height of the whorl section is almost equal $(\mathrm{ww} / \mathrm{wh}=0.95)$. Ribs are not preserved.

Discussion: The specimen has an umbilical width index $(\mathrm{uw} / \mathrm{dm}=0.33)$ similar to those of the two specimens of Melchiorites lechicus ( 0.29 and 0.34 , respectively) figured in plate XV of 
Uhlig (1883). But our specimen shows much more rounded flanks and lacks constrictions, which are a diagnostic character of Melchiorites.

Subfamily Beudanticeratinae Breistroffer, 1953

Genus Beudanticeras (Beudanticeras) Hitzel, 1902

Beudanticeras cf. beudanti (Brongniart, 1822)

Fig. 7I, X-AA, AL, AM.

Synonymy: See Klein and Vašíček (2011).

Lectotype: Ammonites Beudanti Brongniart, 1822, p. 394, pl. VII, figs. 2A, B.

Material: 7 conchs (NMSG Coll. PK. 7.B.17.01, 7.B.20.03, 7.B.20.04, 7.B.20.14, 7.B.20.41, 7.B.25.10, 7.B.26.03), 1 shell fragment (NMSG Coll. PK. 7.B.20.39).

Locality and horizon: Schlatt (above Rüthi SG; NMSG Coll. PK. 7.B.20.14, 7.B.20.41, 7.B.20.39, 7.B.20.04, 7.B.20.03), Stofel, Lenziwis (NMSG Coll. PK. 7.B.26.03), Oberrieter Strüssler SE (NMSG Coll. PK. 7.B.17.01), Bergli, Sennwald (NMSG Coll. PK. 7.B.25.10), Garschella Formation, Albian.

Description: NMSG (Coll. PK. 7.B.20.14) measures $73 \mathrm{~mm}$ in diameter. The conch is extremely discoidal $(\mathrm{ww} / \mathrm{dm}=0.30)$ and involute $(\mathrm{uw} / \mathrm{dm}=0.13)$. The whorl section is oval and very compressed $(\mathrm{ww} / \mathrm{wh}=0.56)$ with flat to broadly arched venter. Ribs are faint but present. It appears that they are more comspicuous on the outer flank than on the inner flank. There are about 8 blunt ribs per whorl. NMSG (Coll. PK. 7.B.20.41) measures $61 \mathrm{~mm}$ in diameter. The conch is extremely discoidal $(\mathrm{ww} / \mathrm{dm}=0.27)$ and sub- involute $(\mathrm{uw} / \mathrm{dm}=0.16)$. The whorl section is oval and very compressed $(\mathrm{ww} / \mathrm{wh}=0.55)$ with flat to broadly arched venter. Slightly sigmoidal ribs are visible on the outer whorl but only faintly developed on the inner whorl. 
Discussion: The umbilical width index of the type specimen (Plate VII, Fig 2, Brongniart $1822 ; \mathrm{uw} / \mathrm{dm}=0.18$ ) is similar to those of our specimens. Weak ornamentation, compressed whorl cross section, flattened flanks and steep umbilical shoulder characterize the species. Occurrence: Lower Cretaceous (lower part of upper Albian to the early uppermost Albian); England, France, Italy (Saridinia), Switzerland, Austria, Hungary, Caucasus, Iran, Angola, Morocco.

Subfamily Desmoceratinae Zittel, 1895

Genus Desmoceras (Desmoceras) Zittel, 1885

Desmoceras (Desmoceras) latidorsatum (Michelin, 1838)

Fig. 6AH, AI, 8U, V, 9E, F.

Synonymy: See Kennedy and Fatmi (2014).

Holotype: Ammonites latidorsatus Michelin, 1838, p. 101, pl. 10, fig. 9.

Material: 1 heavily eroded conch (NMSG Coll. PK. 7.B.32.04). 2 internal moulds (NMSG Coll. PK. 7.B.37.10, 7.C.15.15).

Locality and horizon: Chelen-Geren (SW Plona; NMSG Coll. PK. 7.B.37.10), Wildhuser Schafboden gegen Pt. 2171 (NMSG Coll. PK. 7.B.32.04), Garschella Formation, Albian; Hinterwinden-Hornwald (Hinter Gräppelen; NMSG Coll. PK. 7.C.15.15), Kamm Bed, uppermost Albian-lowermost Cenomanian.

Description: NMSG (Coll. PK. 7.B.32.04) measures $41 \mathrm{~mm}$ in diameter. The conch is thickly dicoidal $(\mathrm{ww} / \mathrm{dm}=0.49)$ and involute $(\mathrm{uw} / \mathrm{dm}=0.13)$. Its whorl section is compressed $(\mathrm{ww} / \mathrm{wh}=0.88)$ with broadly rounded flanks and venter. There is only one constriction preserved. NMSG (Coll. PK. 7.B.37.10) measures $21 \mathrm{~mm}$ in diameter. Its conch is thinly pachyconic $(\mathrm{ww} / \mathrm{dm}=0.61)$ and subinvolute $(\mathrm{uw} / \mathrm{dm}=0.24)$. The whorl cross section is rectangular and much wider than high $(\mathrm{ww} / \mathrm{wh}=1.34)$. Six straight to faintly curved constrictions are present per whorl. 
Discussion: See Wiedmann and Dienni (1968) and Kennedy and Fatmi (2014).

Occurrence: Lower-Upper Cretaceous (middle Albian-late Cenomanian); England, Spain, France, Germany, Italy (Sardinia), Switzerland, Austria, Hungary, Poland, Serbia, Ukraine, Pakistan, India, Angola, Egypt, Madagascar, Mozambique, South Africa (KwaZulu-Natal), Tunisia,.USA (off Florida), Cuba,Venezuela, Japan.

Superfamily Pulchelliaceae Douvillè, 1890

Family Pulchellidae Douvillè, 1890

Genus Kotetishvilia Vermeulen, 1997

Kotetishvilia compressissima (d'Orbigny, 1841)

Fig. 6R, S.

Synonymy: See Vermeulen (2002). The species was also referred to by Vermeulen (2014).

Holotype: Ammonites compressissimus d'Orbigny, 1841; p. 210, pl. 61, fig. 4, 5.

Material: 3 conchs (NMSG Coll. PK. 5.A.05.81, 5.A.05.26, 5.A.05.82).

Locality and horizon: Altmann-Sattel, Südwest-Seite I, Altmann Member, uppermost

Hauterivian-upper lower Barremian.

Description: NMSG (Coll. PK. 5.A.05.26) measures $40 \mathrm{~mm}$ in diameter.The conch is involute $(\mathrm{uw} / \mathrm{dm}=0.04)$. There are 14 ribs per half whorl, which are stronger on the dorsal part of the flank than ventrally. The venter is flat while the flank is convex with its maximum width on the midflank.

Discussion: See Vermeulen (2002).

Occurrence: Lower Cretaceous (lower Barremian, K. compressissima Zone); Spain, France, Italy, Switzerland, Austria, Czech Republic, Slovakia, Hungary, Romania, Bulgaria, Russia, Morocco, USA (California), Colombia. 
Nicklesia pulchella (d'Orbigny, 1841)

Fig. 6T, U.

Synonymy: See Vermeulen (2002). The species was also referred to by Vermeulen (2014).

Lectotype: Ammonites pulchellus d'Orbigny, 1841, p. 133, pl. 40, fig. 1, 2.

Material: 1 conch (NMSG Coll. KT. AS-W-0026).

Locality and horizon: Altmann-Sattel, Südwest-Seite I, Altmann Member, uppermost Hauterivian-upper lower Barremian.

Description: NMSG (Coll. KT. AS-W-0026) measures $31 \mathrm{~mm}$ in diameter. The conch is thinly discoidal $(\mathrm{ww} / \mathrm{dm}=0.39)$ and involute $(\mathrm{uw} / \mathrm{dm}=0.10)$. The whorl section is oval and much higher than wide $(\mathrm{ww} / \mathrm{wh}=0.71)$. The venter is slightly rounded. Ribs are stronger on the ventral part of the flank than dorsally. 13 ribs present in half a whorl.

Discussion: See Vermeulen (2002).

Occurrence: Lower Cretaceous (lower Barremian; Nicklesia pulchella Zone); Spain, France, Italy, Switzerland, Austria, Hungary, Romania, Crimea, Georgia, Algeria, Tunisia, Morocco, Colombia.

Superfamily Perisphinctaceae Steinmann, 1890

Family Holcodiscidae Spath, 1923

Genus Astieridiscus Kilian, 1910

Astieridiscus morleti (Kilan, 1889)

Fig. 8AC, AD.

Synonymy: See Klein (2005).

Type: Holcodiscus Morleti, Kilian 1889; p. 676. Pl. XVII, figs. 4a, b.

Material: 1 conch (NMSG Coll. PK. 5A.13.06).

Locality and horizon: Wis (SW Alp Rohr), Altmann Member, uppermost Hauterivian-upper lower Barremian. 
Description: NMSG (Coll. PK. 5A.13.06) measures $30 \mathrm{~mm}$ in diameter. Its conch is extremely thinly to thinly discoidal $(\mathrm{ww} / \mathrm{dm}=0.29)$ and subinvolute $(\mathrm{uw} / \mathrm{dm}=0.28)$. The whorl section is slightly higher than wide $(\mathrm{ww} / \mathrm{wh}=0.90)$ with flattened flanks. Fine ribs are single or bifurcate on the midflank.

Discussion: The specimen is similar to the holotype in having fine and bifurcated ribs, a similar whorl section and umbilical width index.

Occurrence: Lower Cretaceous (lower Barremian, N. pulchella Zone); France, Bulgaria, Crimea, Georgea, Carribean.

Genus Holcodiscus Uhlig, 1882

Holcodiscus caillaudianus (d'Orbigny, 1850)

Fig. 9M, N, U, V.

Synonymy: See Klein (2005).

Type: Holcodiscus tzankovi Avram, p. 17, pl. 3, fig. 10.

Material: 8 conchs (NMSG Coll. PK. 5.A.05.03, 5.A.05.22, 5.A.05.23, 5.A.05.27, 5.A.05.83 to 5.A.05.85, 5.A.17.02).

Locality and horizon: Altmann-Sattel, Südwest-Seite I (NMSG Coll. PK. 5.A.05.03, 5.A.05.22, 5.A.05.23, 5.A.05.27, 5.A.05.83 to 5.A.05.85), Chobel, Frümsner Berg (NMSG Coll. PK. 5.A.17.02), Altmann Member, latest Hauterivian-late Barremian.

Description: NMSG (Coll. PK. 5.A.05.85) measures $33 \mathrm{~mm}$ in diameter. The conch is thinly to moderately discoidal $(\mathrm{ww} / \mathrm{dm}=0.47)$ and subinvolute $(\mathrm{uw} / \mathrm{dm}=0.24)$. Height and width of the whorl section is more or less equal $(\mathrm{ww} / \mathrm{wh}=0.98)$ with a slightly flattened venter. Fine and straight to flexuose ribs are truncated by thickened ribs on which ventral tubercles are present. 3 to 6 fine ribs are visible between the thickened ribs. NMSG (Coll. PK. 5.A.05.86) measures $36 \mathrm{~mm}$ in diameter. Its conch is discoidal $(\mathrm{ww} / \mathrm{dm}=0.48)$ and subinvolute $(\mathrm{uw} / \mathrm{dm}$ $=0.26)$. The whorl section is wider than high $(\mathrm{ww} / \mathrm{wh}=1.16)$ with a slightly flattened ventral 
side. Fine and more or less straight ribs are truncated by thickened ribs. Ventral and lateral tubercles are well developed on the thickened ribs. The thickened ribs are often bifurcated by the lateral tubercles. 5 to 6 fine ribs are developed between the thickened ribs.

Discussion: See Avram (1995).

Occurrence: Lower Cretaceous (lower Barremian, K. compressissima Zone); France, Hungary, Czech Republic, ?Poland (Silesia), Bulgaria, Romania, Caucasus, Crimea, Switzerland.

\section{Holcodiscus sp.}

Fig. 8AA, AB.

Material: 2 conchs (NMSG Coll. PK. 5.A.05.42, 5.A.16.01).

Locality and horizon: Altmann-Sattel, Südwest-Seite I (NMSG Coll. PK. 5.A.05.42),

Vorderalp, Frümsner Alp (NMSG Coll. PK. 5.A.16.01), Altmann Member, uppermost Hauterivian-upper lower Barremian.

Description: NMSG (Coll. PK. 5.A.05.42) measures $27 \mathrm{~mm}$ in diameter. Its conch is thickly discoidal $(\mathrm{ww} / \mathrm{dm}=0.51)$ and subinvolute $(\mathrm{uw} / \mathrm{dm}=0.27)$. The whorl section is rounded and wider than high $(\mathrm{ww} / \mathrm{wh}=1.10)$. Ribs are moderately coarse and occasionally bifurcating from lateral tubercles. No tubercles are developed on the rounded venter. NMSG (Coll. PK. 5.A.16.01) measures $28 \mathrm{~mm}$ in diameter. Its conch is thinly discoidal $(\mathrm{ww} / \mathrm{dm}=0.38)$ and subinvolute $(\mathrm{uw} / \mathrm{dm}=0.24)$. The whorl section is higher than wide $(\mathrm{ww} / \mathrm{wh}=0.84)$ with a flattened venter. Ribs are bifurcating on the flank. There are two rows of ventral tubercles between which the ribs are hardly visible.

Discussion: The constant ribs of NMSG (Coll. PK. 5.A.05.42) without tuberculation resemble H. uhligi but our specimen shows a much wider whorl section and bears coarser ribs. The ribs of A. morleti are also similar but our specimen has a much wider whorl section. Our specimen may be a depressed variant of $H$. uhligi or $A$. morleti which are actually very similar to each 
other. The whorl section of NMSG (Coll. PK. 5.A.16.01) is like Holcodiscus diversecostatus but our specimen bears primary and secondary ribs, which differ from $H$. diversecostatus. Occurrence: Lower Cretaceous (lower Barremian, N. pulchella-K. compressissima Zones; for the genus).

Genus Parasaynoceras Breistroffer, 1947

Parasaynoceras tzankovi (Avram, 1995)

Fig. 9W, X

Types: Holcodiscus caillaudianus Uhlig, p. 243-244, pl. 19, figs 2-4, 6, 7, 13, 14.

Material: 1 chonch (NMSG Coll. PK. 5.A.05.86).

Locality: Altmann-Sattel, Südwest-Seite I, (NMSG Coll. PK. 5.A.05.86), Altmann Member, latest Hauterivian-late early Barremian.

Description: NMSG (Coll. PK. 5.A.05.86) measures $36 \mathrm{~mm}$ in diameter. Its conch is discoidal $(\mathrm{ww} / \mathrm{dm}=0.48)$ and subinvolute $(\mathrm{uw} / \mathrm{dm}=0.26)$. The whorl section is wider than high $(\mathrm{ww} / \mathrm{wh}=1.16)$ with a slightly flattened ventral side. Fine and more or less straight ribs are truncated by thickened ribs. Ventral and lateral tubercles are well developed on the thickened ribs. The thickened ribs are often bifurcated by the lateral tubercles. 5 to 6 fine ribs are developed between the thickened ribs.

Discussion: According to Avram (1995), this species is similar to $H$. caillaudianus and $H$. perezianus but differs in having subcircular a whorl section, a high whorl expansion rate and strong lateral tubercles.

Occurrence: Lower Cretaceous (lower Barremian); France, Romania, Bulgaria, Crimea, Georgia.

Superfamily Hoplitaceae Douvillé, 1890

Family Hoplitidae Douvillé, 1890 
Subfamily Hoplitinae Douvillé, 1890

Genus Callihoplites Spath, 1925a

Callihoplites tetragonus (Seeley, 1865)

Fig. 9Q. R.

Synonymy: See Kennedy et al. (2008).

Holotype: Ammonites raulinianus var. tetragonus Seeley, 1865; p. 243.

Material: 1 conch (NMSG Coll. UO. 017).

Locality and horizon: Säntis, Kamm Bed, uppermost Albian-lowermost Cenomanian.

Description: NMSG (Coll. UO. 017) measures $48 \mathrm{~mm}$ in diameter. The conch is discoidal $(\mathrm{ww} / \mathrm{dm}=0.50)$ and subinvolute $(\mathrm{uw} / \mathrm{dm}=0.29)$. The whorl section is wider than high $(\mathrm{ww} / \mathrm{wh}=1.14)$ with rounded venter. The maximum thickness is at the umbilical edge. Umbilical tubercles give rise to one or two pairs of looped ribs, which bear ventrolateral tubercles. The numbers of umbilical and ventrolateral tubercles per whorl are 10 and about 16 , respectively.

Discussion: See Kennedy et al. (2008).

Occurrence: Lower Cretaceous (upper Albian, M. fallax Zone); England, France, Belgium, Switzerland, Tibet.

Genus Hyphoplites Spath 1922

Hyphoplites curvatus curvatus Mantell, 1822

Fig. 9AC, AD.

Synonymy: See Kennedy (1994). The species was also mentioned by Gauthier (2006).

Holotype: Hyphoplites curvatus curvatus Mantell, 1822; p. 118, pl. 21, fig.18.

Material: 1 conch fragment (NMSG Coll. TB. STWG_CE34)

Locality and horizon: Blauschnee-Girenspitz, Kamm Bed, uppermost Albian-lowermost Cenomanian. 
Description: NMSG (Coll. TB. STWG_CE34) measures $41 \mathrm{~mm}$ in diameter. Its whorl height and width are nearly the same $(\mathrm{ww} / \mathrm{uw}=0.97)$. The flanks are flattened with fine ribs.

Umbilical bullae give rise to 3 to 4 prosiradiate ribs. There are inner- and outer well-

developed ventrolateral tubercles interrupting some of the ribs. A siphonal groove is present. Discussion: See Wright and Kennedy (1984).

Occurrence: Upper Cretaceous (lower Cenomanian); England, France, Germany, Romania, Crimea, Iran, Turkmenistan.

Superfamily Acanthocerataceae Grossouvre, 1894

Family Brancoceratidae Spath, 1934

Subfamily Brancoceratinae Spath, 1934

Hysteroceras binum (Sowerby, 1815)

Fig. 7AB, AC.

Synonymy: See Lehmann et al. (2007).

Holotype: Ammonites binus Sowerby, 1815; p. 208, pl. 92, fig.3.

Material: 1 conch (NMSG Coll. PK. 7.B.20.36).

Locality and horizon: Schlatt (above Rüthi SG), Garschella Formation, Albian.

Description: NMSG (Coll. PK. 7.B.20.36) measures $27 \mathrm{~mm}$. The conch is involute (uw/dm = $0.32)$ and extremely discoidal $(\mathrm{ww} / \mathrm{dm}=0.29)$. The whorl section is compressed $(\mathrm{ww} / \mathrm{wh}=$ 0.74). There are 15 ventrolateral bullae per half whorl. Ribs are faint on the midflank. The keel is distinct.

Discussion: According to Spath (1934), this species is very compressed with flattened flanks. The inner bullae are prominent.

Occurrence: upper Albian; England, Spain, Italy (Sadinia), Hungary, Bulgaria, Dagestan, Turkmenistan, Angola, Madagascar, Nigeria, Mexico. 
Hysteroceras crassicostatum (Jayet, 1929)

Fig. 7T, U.

Synonymy: See Föllmi (1989b).

Type: Schloenbachia (Pervinquieria) varicosa var. crassicostata Jayet, 1929; p. 4, 5, fig. 7, no.

2.

Material: 1 shell fragment (NMSG Coll. PK. 7.B.26.16).

Locality and horizon: Stofel, Lenziwis, Garschella Formation, Albian.

Description: NMSG (Coll. PK. 7.B.26.16) is a partially weathered specimen, measuring 23 $\mathrm{mm}$ in diameter. The conch is thinly discoidal $(\mathrm{ww} / \mathrm{dm}=0.46)$ and sub-evolute $(\mathrm{uw} / \mathrm{dm}=$ 0.40). The whorl section is rectangular and much wider than high $(\mathrm{ww} / \mathrm{wh}=1.32)$. The ribs are more or less straight, which number 23 per whorl. Some of them are bifurcated. Blunt umbilical bullae give rise to one or two ribs. The weak keel separates the ribs.

Discussion: According to Föllmi (1989b), the species has a depressed whorl section with widely spaced ribs. Ribs are simple or bifurcated. H. orbignyi is similar to this species but differs in having denser ribbing. H. varicosum is also similar but differs in having simple ribs. Occurrence: Lower Cretaceous (upper Albian, Mortoniceras Inflatum Zone); England, France, Austria, Madagascar.

Genus Hysteroceras Hyatt, 1900

Hysteroceras orbignyi Spath, 1922

Fig. 7P-S.

Synonymy: See Föllmi (1989b).

Type: Ammonites varicosus Sowerby, determined in d'Orbigny,1841; p. 294, pl. 87, fig. 3.

Material: 6 shell fragments (NMSG Coll. PK. 7.B.25.02, 7.B.25.34, 7.B.26.06, 7.B.25.35,

7.B.26.15, 7.B.26.22). 
Locality and horizon: Bergli, Sennwald (NMSG Coll. PK. 7.B.25.02, 7.B.25.34, 7.B.25.35),

Stofel, Lenziwis (NMSG Coll. PK. 7.B.26.06, 7.B.26.22, 7.B.26.22), Garschella Formation, Albian.

Description: NMSG (Coll. PK. 7.B.25.02) is a well preserved specimen measuring $22 \mathrm{~mm}$ in diameter. The conch is extremely discoidal $(\mathrm{ww} / \mathrm{dm}=0.32)$ and subevolute $(\mathrm{uw} / \mathrm{dm}=0.40)$. The whorl section is rounded and slightly higher than wide (ww/wh $=0.90)$. The ribs are weakly curved, there are about 16 per half whorl. Some of them are bifurcated.

Discussion: According to Spath (1934), the species has a subquadrate whorl cross section, which varies from slightly compressed to slightly depressed. Traces of a blunt keel are present in early ontogenetic stages. Ribs are bifurcating or long and short in alternation. Renz (1982) stated that the majority of ribs on the outer whorl are bifurcating from umbilical bullae but occasionally are single.

Occurrence: Lower Cretaceous (upper Albian, Mortoniceras inflatum Zone, H. orbignyi Subzone); Spain, France, Switzerland, Poland, Romania, Slovakia, Ukraine, Georgia, Angola, Madagascar, Mozambique, South Africa (KwaZulu-Natal), USA (Texas), Venezuela.

Hysteroceras varicosum (Sowerby, 1824)

Fig. 7AJ, AK.

Synonymy: See Marcinowski and Wiedmann (1990).

Type: Ammonites varicosus Sowerby 1824; p.74, pl. 451, fig.5.

Material: 1 shell fragment (half of the conch missing; NMSG Coll. PK. 7.B.23.21) and 1 weathered conch (NMSG Coll. KT. Dü-St-0003).

Locality and horizon: In Ränken, Plona (NMSG Coll. PK. 7.B.23.21), Garschella Formation, Albian; Stofel, Lenziwis (NMSG Coll. KT. Dü-St-0003), the Wannenalp Bank, Albian. Description: NMSG (Coll. PK. 7.B.23.21) is $31 \mathrm{~mm}$ in maximum measurable diameter. The conch is thinly discoidal $(\mathrm{ww} / \mathrm{dm}=0.35)$ and subevolute $(\mathrm{uw} / \mathrm{dm}=0.40)$. The whorl height 
and width are nearly equal $(\mathrm{ww} / \mathrm{wh}=1.02)$. The ribs are coarse, more or less straight and broad, about 15 per whorl. Umbilical bullae give rise to ribs with occasional intercalated ribs in between. There is a blunt keel on the venter.

Discussion: According to Marcinowski and Wiedmann (1990), the species has a rectangular whorl section $(\mathrm{ww} / \mathrm{wh}=1.0)$ and a strong ventrolateral tuberculation. Spath (1934) mentioned that ribs are rarely bifurcating but mostly, there are alternating long and short ribs. Our specimen is similar to Sowerby's holotype figured in Spath (1934).

Occurrence: Lower Cretaceous (upper Albian; Hysteroceras varicosum Subzone; Casey, 1966); England, France, Germany, Poland, Romania, Serbia, Ukraine, Crimea, Angola, Madagascar, USA (Texas), Mexico, Venezuela, Suriname.

Subfamily Mortoniceratinae Douvillé, 1912

Genus Cantabrigites Spath, 1933

Cantabrigites sp.

Fig. 7AE-AI.

Material: 5 conchs (NMSG Coll. PK. 7.B.35.01, 7.C.13.14, 7.C.15.10, 7.C.15.21, 7.C.15.31). Locality and horizon: Hinterwinden-Hornwald (Hinter Gräppelen; NMSG Coll. PK.

7.C.15.10, 7.C.15.21, 7.C.15.31), Säntis, Gasthaus-Hang (NMSG Coll. PK. 7.C.13.14), Kamm Bed, uppermost Albian-lowermost Cenomanian; Tal W II (NE Neuenalpspitz; NMSG Coll. PK. 7.B.35.01), Garschella Formation, Albian.

Description: NMSG (Coll. PK. 7.C.15.31) is $21 \mathrm{~mm}$ in maximum diameter. The conch is extremely discoidal $(\mathrm{ww} / \mathrm{dm}=0.34)$ and subevolute $(\mathrm{uw} / \mathrm{dm}=0.42)$. The whorl section is rectangular and only slightly higher than wide $(\mathrm{ww} / \mathrm{wh}=0.91)$. There are 17 ribs per whorl. Umbilical bullae give rise to coarse ribs with intercalated ribs. The moderately distinct keel separates the ribs on the venter. NMSG (Coll. PK. 7.C.15.21) measures $29 \mathrm{~mm}$ in diameter. The conch is extremely discoidal $(\mathrm{ww} / \mathrm{dm}=0.32)$ and subevolute $(\mathrm{uw} / \mathrm{dm}=0.40)$. The whorl 
section is rectangular and slightly higher than wide $(\mathrm{ww} / \mathrm{wh}=0.93)$. The ribs are very coarse and carry two to three bullae. There are 15 ribs per half whorl. The keel is conspicuous. NMSG (Coll. PK. 7.C.13.14) reaches $30 \mathrm{~mm}$ in diameter. Its conch is extremely discoidal $(\mathrm{ww} / \mathrm{dm}=0.30)$ and subevolute $(\mathrm{uw} / \mathrm{dm}=0.42)$. The whorl section is rectangular and slightly higher than wide $(\mathrm{ww} / \mathrm{wh}=0.91)$. Its ribs are coarse and carry inner and outer ventrolateral tubercles. There are 29 ribs per whorl.

Discussion: Cantabrigites was documented as a genus with very small conchs with simple ribs, relatively strong ventrolateral tubercles and distinct keels, but sometimes these characters are developed very similarly to Hysteroceras. Mortoniceras also shows similar characters, perhaps because it may be the macroconch counterpart of Cantabrigites and Hysteroceras. Thus, these three genera often are confused and thus wrongly determined. A quantitative analysis of conch morphology based on well-preserved materials is needed to revise the taxonomy of these genera.

Occurrence: Lower Cretaceous (upper Albian; for the genus); England, France, Switzerland.

Mortoniceras perinflatum (Sowerby, 1817)

Fig. 8A, B.

Synonymy: See Kennedy and Latil (2007).

Holotype: Ammonites inflatus Pictet and Campiche 1860, p. 178, pl. 21, figs. 5; pl. 22, fig. 3. Material: 1 shell fragment (NMSG Coll. KT. HW-A-0030).

Locality and horizon: Hinterwinden-Hornwald (Hinter Gräppelen), Kamm Bed, Albian. Description: NMSG (Coll. KT. HW-A-0030) is $58 \mathrm{~mm}$ long. The conch is pachyconic $(\mathrm{ww} / \mathrm{dm}=0.61)$ with depressed and rectangular whorl section $(\mathrm{ww} / \mathrm{wh}=1.35)$. Ribs are dense with angles of around $18^{\circ}$ between two succeeding ribs. There are 4 tubercles on each rib. 
Discussion: According to Kennedy and Latil (2007), M. perinflatum is similar to M. rostratum but differs in having a more depressed whorl section.

Occurrence: Lower Cretaceous (upper Albian, M. perinflatum Zone); England, France, Switzerland, Hungary, Romania, Crimea, Caucasus, Iran, Angola, South Africa (KwaZuluNatal), USA (Texas).

Mortoniceras rostratum (Sowerby, 1817)

Fig. $8 \mathrm{G}, \mathrm{H}$.

Synonymy: See Kennedy and Latil 2007

Holotype: Ammonites rostratus Sowerby 1817, p. 163, pl. 173.

Material: 1 conch (NMSG Coll. PK. 7.B.20.57) from Garschella-Formation, Alpstein.

Locality and horizon: Schlatt (above Rüthi SG), Garschella Formation, Albian.

Description: NMSG (Coll. PK. 7.B.20.57) is an eroded specimen, measuring $50 \mathrm{~mm}$ in conch diameter. The conch is sub-evolute $(\mathrm{uw} / \mathrm{dm}=0.36)$. The whorl section is rectangular and higher than wide $(\mathrm{ww} / \mathrm{wh}=0.67)$. There are 18 multituberculated ribs per half whorl. The number of tubercles on a rib is approximately 5 .

Discussion: See discussion for M. inflatum above.

Occurrence: Lower Cretaceous (upper Albian, M. rostratum Zone); England, Spain, France, Germany, Hungary, Romania, Caucasus, Iran, Turkmenistan, USA (Texas), Japan.

Genus Mortoniceras (Mortoniceras) Meek, 1876

Mortoniceras cf. inflatum (Sowerby, 1818)

Fig. 8E, F, I, J.

Synonymy: See Amédro et al. (2004)

Holotype: Ammonites inflatus Sowerby, 1818; p. 170, pl. 178. 
Material: 4 shell fragments (NMSG Coll. PK. 7.B.20.24, 7.B.20.25, 7.B.20.44, NMSG Coll.

KT. Rü-S-0021)

Locality and horizon: Schlatt (above Rüthi SG), Garschella Formation, Albian.

Description: NMSG (Coll. KT. Rü-S-0021) measures $163 \mathrm{~mm}$ in diameter. The conch is extremely discoidal $(\mathrm{ww} / \mathrm{dm}=0.34)$ and subevolute $(\mathrm{uw} / \mathrm{dm}=0.36)$. The whorl section is slightly compressed $(\mathrm{ww} / \mathrm{wh}=0.92)$ with flattened flank. There are primary ribs, originating from umbilical tubercles, intercalated by secondary ribs. On the phragmocone, the ribs are more closely spaced (angle between two ribs is approximately $20^{\circ}$ ) than on the body chamber $\left(\right.$ more or less $40^{\circ}$ ). There are 3 tubercles present on the phragmocone, which are stronger than on the body chamber.

Discussion: M. inflatum has 3 tubercles, one of which can become a bulla during late ontogeny on the primary ribs. $M$. pricei, $M$. fallax and $M$. rostratum have two, three and four tubercles, respectively. Our specimens carry 3 tubercles on a rib but the ornamentation is very weak, which hampers the clear separation from M. fallax For a revision of Mortoniceras, see Amédro et al. (2004).

Occurrence: Lower Cretaceous (upper Albian, Mortoniceras inflatum Zone); France, Germany, Poland, Russia, Crimea, Georgia, Angola, Morocco, Tunisia, Japan.

\section{Mortoniceras sp.}

Fig. 8C, D.

Material: 1 shell fragment (NMSG Coll. PK. 7.B.20.20).

Locality and horizon: Schlatt (above Rüthi SG), Garschella Formation, Albian.

Description: NMSG (Coll. PK. 7.B.20.20) is a conch fragment, measuring $113 \mathrm{~mm}$ in diameter. Its whorl section appears to be as high as wide or slightly higher than wide. There are 2 tubercles on each rib. The interspace is wide. 
Discussion: According to Amedro (2004), M. pricei has developed two tubercles on a rib, which corresponds to our specimen. But the holotype of Spath (1930) shows more closely spaced septa.

Occurrence: Lower Cretaceous (upper Albian; for the genus).

Subfamily Mojsisovicziinae Hyatt, 1903

Genus Dipoloceras Hyatt, 1900

Dipoloceras cf. pseudaon Spath, 1931

Fig. 8K, L.

1931. Dipoloceras pseudaon Spath, p.373. pl. XXXII, Fig. 11; pl. XXXIV, figs. 1-3.

2011. Dipoloceras boucharidianum, Gale et al., fig. 20B. no description.

Holotype: Dipoloceras pseudaon Spath, 1931; p. 373, pl. 14, figs. 1-3.

Material: 1 phragmocone fragment (NMSG Coll. PK. 7.B.20.23).

Locality and horizon: Schlatt (above Rüthi SG; NMSG Coll. PK. 7.B.20.23), Garschella Formation, Albian.

Description: NMSG (Coll. PK. 7.B.20.23) is a weathered specimen, measuring $79 \mathrm{~mm}$ in diameter. The whorl section is nearly rectangular and compressed $(\mathrm{ww} / \mathrm{wh}=0.78)$ with a sulcate venter and a keel. Weakly sigmoidal ribs are bifurcating between the midflank and umbilical shoulder. Approximately 30 ribs are present per half whorl.

Discussion: The species is similar to D. elegans in having a compressed and oval whorl section and sigmoidal ribs, but D. elegans has more strongly developed ventrolateral tubercles. Our specimen is also similar to D. pseudaon var. moniliformis in Spath (1931; pl. XXXII, fig. 10) in its fine ribbing and relatively flattened flank but the holotype of D. pseudaon is somewhat less compressed than our specimen.

Occurrence: Lower Cretaceous (upper Albian); England, France, Colombia, Japan. 
Family Acanthoceratidae de Grossouvre, 1894

Subfamily Mantelliceratinae Hyatt, 1903

Genus Mantelliceras Hyatt, 1903

Mantelliceras saxbii (Sharpe, 1857)

Fig. 8Q, R, W, X, AE, AF.

Synonymy: See Kennedy et al. 2015.

Lectotype: Ammonites Saxbii Sharpe, 1857; p. 45, pl. 20, fig. 3.

Material: 8 conchs (NMSG Coll. PK. 7.C.02.03, 7.C.03.03, 7.C.11.02, 7.C.13.27, 7.C.13.28,

NMSG Coll. UO. 002, 003, NMSG Coll. KT. TW-G-0001).

Locality and horizon: Stütze 2 Säntisbahn S. (NMSG Coll. KT. TW-G-0001), Tierwis NE II

(NMSG Coll. PK. 7.C.03.03), Säntis, Gasthaus-Hang (NMSG Coll. PK., 7.C.13.27,

7.C.13.28), Stütze 2 Säntisbahn S (NMSG Coll. PK. 7.C.02.03), Säntis, Gasthaus-Galerie and surrounding (NMSG Coll. PK. 7.C.11.02), Säntis (STG_4, NMSG Coll. UO. 002, 003), Kamm Bed, uppermost Albian-lowermost Cenomanian.

Description: NMSG (Coll. UO. 002) measures $70 \mathrm{~mm}$ in diameter. The conch is extremely thinly discoidal $(\mathrm{ww} / \mathrm{dm}=0.34)$ and subinvolute $(\mathrm{uw} / \mathrm{dm}=0.27)$. The flank is more or less flat with the maximum width in the middle. There are 20 ribs on the last demi-whorl. The ribs, which are finer and denser on the inner whorl than on the outer, are nearly straight to feebly concave toward the aperture. Ventrolateral tubercles and umbilical bullae are relatively prominent but there are no conspicuous lateral tubercles.

Discussion: According to Wright and Kennedy (1984), M. picteti and M. saxbii are the species with compressed whorl section and flat flank. M. picteti develops strong ribs with quadrituberculation, which distinguishes the two species.

Occurrence: Upper Cretaceous (lower Cenomanian, M. mantelli Zone, common in M. saxbii Subzone); England, Spain, France, Germany, Switzerland, Poland, Romania, Bulgaria, Kazakhstan, Iran, Angola, Madagascar, South Africa (KwaZulu-Natal), Tunisia, Japan. 
Family Lyelliceratidae, Spath 1921

Subfamily Stoliczkaiellinae, Cooper 2012

Genus Stoliczkaiella Cooper, 2012

Subgenus Stoliczkaiella Cooper, 2012

Stoliczkaiella (Stoliczkaiella) clavigera (Neumayr, 1875)

Figs. 8O, P. 9C, D.

Synonymy: See Kennedy and Klinger (2013).

Holotype: Ammmonites dispar Stoliczka, 1864; p. 85, pl. 45, fig. 1.

Material: 4 conchs (NMSG Coll. PK. 7C.12.04, 7.C.12.05, 7.C.13.04, NMSG Coll. UO. 003).

Locality and horizon: Säntis, (NMSG Coll. UO. 003), Ebenalp, Übergang gegen Gartenalp

(NMSG Coll. PK. 7C.12.04, 7.C.12.05), Säntis, Gasthaus-Hang (NMSG Coll. PK. 7.C.13.04),

Kamm Bed, uppermost Albian-lowermost Cenomanian.

Description: NMSG (Coll. PK. 7C.12.04) measures $47 \mathrm{~mm}$ in diameter. Its conch is thinly discoidal $(\mathrm{ww} / \mathrm{dm}=0.40)$ and subinvolute $(\mathrm{uw} / \mathrm{dm}=0.23)$. The whorl section is slightly compressed $(\mathrm{ww} / \mathrm{wh}=0.90)$ with flattened flanks and broadly rounded venter. There are 32 ribs per whorl. The ribs, which are finer and denser on the inner whorl than on the outer, are nearly straight and originate from small umbilical bullae. Primary ribs are intercalated between secondary ribs or bifurcating.

Discussion: See Wright and Kennedy (1994) as well as Kennedy and Klinger (2013).

Occurrence: Lower Cretaceous (upper Albian M. rostratum and Arrhaphoceras briacensis Zone); England, France, Switzerland, Romania, Turkmenistan, India, Japan.

Stoliczkaiella (Stoliczkaiella) notha (Seeley, 1865)

Fig. 8M, N.

Synonymy: See Wright and Kennedy (1994). 
Lectotype: Ammonites navicularis Mantell var. nothus Seeley 1865; p. 232.

Material: 1 conch (NMSG Coll. PK.7.C.12.03).

Locality and horizon: Ebenalp, Übergang gegen Gartenalp, Kamm Bed, uppermost Albianlowermost Cenomanian.

Description: NMSG (Coll. PK.7.C.12.03) measures $47 \mathrm{~mm}$ in diameter. The conch is thinly discoidal $(\mathrm{ww} / \mathrm{dm}=0.40)$ and involute $(\mathrm{uw} / \mathrm{dm}=0.12)$. The whorl section is compressed $(\mathrm{ww} / \mathrm{wh}=0.74)$ with flattened flanks and broadly rounded venter. There are 32 ribs per whorl. The ribs, which are generated from small umbilical bullae, are nearly straight and mostly bifurcating. There are constant ventrolateral tubercles.

Discussion: See Wright and Kennedy (1994).

Occurrence: Lower Cretaceous (latest Albian, M. rostratum Zone); England, France, Switzerland, Serbia, Romania, Turkmenistan, Crimea, India, Algeria, Angola, Madagascar, USA (California), Japan.

Subgenus Lamnayella Wright and Kennedy, 1978

Stoliczkaiella (Lamnayella) crotaloides (Stoliczka, 1864)

Fig. 8S, T.

Synonymy: See Kennedy and Klinger (2013).

Holotype: Ammonites crotaloides Stoliczka 1864; p. 88, pl. 46, fig. 3.

Material: 1 conch (NMSG Coll. PK. 7.C.12.01).

Locality and horizon: Ebenalp, Übergang gegen Gartenalp, Kamm Bed, uppermost Albianlowermost Cenomanian.

Description: NMSG (Coll. PK. 7.C.12.01) is slightly deformed, measuring $53 \mathrm{~mm}$ in diameter. The conch is thinly discoidal $(\mathrm{ww} / \mathrm{dm}=0.41)$ and subinvolute $(\mathrm{uw} / \mathrm{dm}=0.26)$. The whorl width and height is nearly equal $(\mathrm{ww} / \mathrm{wh}=0.96)$ with flattened flanks and rounded venter. There are 17 straight ribs per whorl. Ribs on the body chamber are distant and blunt while 
those on the phragmocone are rather sharp and less distantly spaced. Ventrolateral bullae are faint.

Discussion: See Kennedy and Klinger (2013).

Occurrence: Lower Cretaceous (upper Albian, M. perinflatum Zone); England, India, Angola, South Africa (KwaZulu-Natal), USA (Texas).

Stoliczkaiella (Lamnayella) juigneti Wright and Kennedy, 1978

Fig. 9I-L.

Synonymy: Wright and Kennedy (1984).

Holotype: Stoliczkaia sp.Wright and Kennedy 1971; p. 398, pl. 37, figs. 1-4

Material: 7 conchs (NMSG Coll. PK. 7.C.01.11, 7.C.05.04, 7.C.11.04, 7.C.11.08, 7.C.11.09, 7.C.15.28, NMSG Coll. KT. HW-A-0024).

Locality and horizon: Hinterwinden-Hornwald (Hinter Gräppelen; NMSG Coll. KT. HW-A0024, NMSG Coll. PK. 7.C.15.28), Säntis, Gasthaus-Galerie and surrounding (NMSG Coll. PK. 7.C.11.04, 7.C.11.08, 7.C.11.09), Hornwald (Hinter Gräppelen; NMSG Coll. PK. 7.C.05.04), Tierwis-Stütze 2 Säntisbahn I (NMSG Coll. PK. 7.C.01.11), Kamm Bed, uppermost Albian-lowermost Cenomanian.

Description: NMSG (Coll. PK. 7.C.05.04) measures $61 \mathrm{~mm}$ in diameter. Its conch is thinly discoidal $(\mathrm{ww} / \mathrm{dm}=0.39)$ and subevolute $(\mathrm{uw} / \mathrm{dm}=0.34)$. The whorl cross section is slightly higher than wide $(\mathrm{ww} / \mathrm{wh}=0.92)$ with flattened flanks and rounded venter. There are 15 straight ribs per half whorl. Primary ribs, on which small bullae are present, are intercalated by shorter and non-bullate ribs.

Discussion: See Wright and Kennedy (1984).

Occurrence: Upper Cretaceous (lower Cenomanian, M. mantelli zone); England, France, Egypt. 
Family Forbesiceratidae Wright, 1952

Genus Forbesiceras Kossmat, 1897

Forbesiceras largilliertianum (d'Orbigny, 1841)

Fig. 90, P.

Synonymy: See Kennedy et al. (2013).

Lectotype: Ammonite largilliertianus d'Orbigny 1841, p. 320, pl. 95.

Material: 1 shell fragment (NMSG Coll. PK. 7.C.13.35).

Locality and horizon: Säntis, Gasthaus-Hang, Kamm Bed, uppermost Albian-lowermost Cenomanian.

Description: NMSG (Coll. PK. 7.C.13.35) is an eroded conch fragment, measuring $92 \mathrm{~mm}$ in diameter. Its conch is involute $(\mathrm{uw} / \mathrm{dm}=0.06)$ and appears very compressed although one side of the flank is not preserved. The venter is very narrow and flat. Ribs are not well preserved but fine.

Discussion: See Delamette and Kennedy (1991) as well as Kennedy et al. (2013).

Occurrence: Upper Cretaceous (lower-middle Cenomanian); England, Spain, France,

Germany, Switzerland, Romania, Iran, India, Algeria, Madagascar, South Africa (KwaZuluNatal), Tunisia, Japan.

Suborder Ancyloceratina Wiedmann, 1966

Superfamily Ancylocerataceae Gill, 1871

Family Bochianitidae Spath, 1922

Subfamily Bochianitinae Spath, 1922

Bochianitinae indet.

Fig. 9AH.

Material: 1 shell fragment (NMSG Coll. KT. ASW_0045). 
Locality and horizon: Altmann-Sattel, Südwest-Seite I, Altmann Member, uppermost Hauterivian-upper lower Barremian.

Description: NMSG (Coll. KT. ASW_0045) is a straight form, measuring $75 \mathrm{~mm}$ in diameter. Its whorl section is slightly rounded $(\mathrm{wh} / \mathrm{ww}=0.84)$. There are 6 distinct prorsiradiate constrictions.

Discussion: The above-mentioned characters are similar to those of Bochianites and Kabylites. According to Wright (1996), the main differences between the two genera lie in the suture line course. Our specimen does not show sutures.

Occurrence: Lower Cretaceous (lower Barremian, N. pulchella-K. compressissima Zones).

Family Ancyloceratidae Gill, 1871

Subfamily Crioceratitinae Gill, 1871

Crioceratitites sp.

Fig. 10C, D.

Material: 1 conch fragment (ETHZ 10438).

Locality and horizon: Altmann, the Altmann Member, uppermost Hauterivian-upper lower Barremian.

Description: ETHZ 10438, whose surface has been evidently carved, measures $157 \mathrm{~mm}$ in diameter. The specimen is loosely coiled (crioconic) with regular and dense ribs with sporadic tubercles. The whorl width and height is more or less equal $(\mathrm{ww} / \mathrm{wh}=0.95)$.

Discussion: Regularly spaced strong and rectiradiate ribs, which are typical for the genus, are not yet developed. The regular, straight ribs are sometimes hardly distinguishable from the artificially carved ribs. The characters mentioned above agree with of the definition of Crioceratites.

Occurrence: Lower Cretaceous (uppermost Valanginian to lower Barremian; for the genus). 
Genus Emericiceras Sarkar, 1954

Emericiceras sp.

Fig. 10B, E.

Material: 5 conchs (NMSG Coll. PK. 5A.02.14, 5A.02.15, NMSG Coll. UO. 006, NMSG

Coll. KT. AS-W-0018, NMSG F 13599).

Locality and horizon: Altmann-Sattel, Südwest-Seite I (NMSG Coll. KT. AS-W-0018), Hüenerberg, (NMSG Coll. UO. 006), Tierwis NE II (NMSG Coll. PK. 5.A.02.14, 5A.02.15), Seealp (NMSG F 13599), Altmann Member, uppermost Hauterivian-upper lower Barremian. Description: NMSG (Coll. PK. 5A.02.15) is an eroded specimen with a diameter of $274 \mathrm{~mm}$. It is loosely coiled (crioconic) and planispiral. Its whorl section is higher than wide but at earlier ontogenetic stages, it is more rounded than in later stages. The main ribs are intercalated by a few minor ribs. Two to three lateral tubercles and ventrolateral spines are present but not well preserved. One side of the flank is deeply eroded and shows no diagnostic features.

Discussion: The conch of this genus is planispirally coiled with a whorl section that is higher than wide. There are periodical main ribs with intercalated finer ribs. According to Wright (1996), this genus differs from Crioceratites in having more frequent and more pronounced periodic ribs with stronger spines. The surface of our specimen is eroded, showing no further details. Honnoratia also shows very similar characters, which could be synonymized.

Occurrence: Lower Cretaceous (late Hauterivian-lower Barremian; for the genus).

Genus Pseudothurmannia Spath, 1923

Pseudothurmannia mortilleti (Pictet and De Loriol, 1858)

Fig. 11AD, AE.

Synonymy: See Hoedemaeker (2013).

Lectotype: Ammonites Mortilleti Pictet and De Loriol, 1958; p. 21, pl. 4, fig. 2a-d. 
Material: 1 conch (STG_11).

Locality and horizon: Locality, unknown, Altmann Member, uppermost Hauterivian-upper lower Barremian.

Description: STG_11 measures $48 \mathrm{~mm}$ in diameter. Its conch is subevolute (uw/ww $=0.34)$. The whorl section appears very compressed with flattened flanks, although one side is missing. Umbilical bullae give rise to densely spaced ribs (45 ribs per half whorl), which are straight to slightly falcoid, and bear occasional bifurcations on the middle of the flank. The venter is nearly straight.

Discussion: See Hoedemaeker (2013).

Occurrence: Lower Cretaceous (latest Hauterivian, Highest Balearites balearis and P. ohmi Zones; Spain, France, Switzerland, Austria, Slovakia, Crimea, Georgia.

Subfamily Leptoceratoidae Thieuloy, 1966

Genus Leptoceratoides Thieuloy, 1966

Leptoceratoides $\mathrm{cf}$. heeri (Ooster, 1860)

Fig. 9AA, AB, AE.

Synonymy: See Karsteniceras? heeri in Vašíček and Wiedmann (1994).

Type: Ancyloceras Heeri Ooster, 1860; p. 32, pl. 38, figs. 1-3, 5.

Material: 3 fragments (NMSG Coll. PK. 5.A.05.24, NMSG Coll. KT. AS-W-0007, AS-W0043).

Locality and horizon: Altmann-Sattel, Südwest-Seite I, the Altmann Member, uppermost Hauterivian-upper lower Barremian.

Description: NMSG (Coll. PK. 5.A.05.24) is a $40 \mathrm{~mm}$ long fragment of a crioconic conch. The whorl section is circular $(\mathrm{ww} / \mathrm{wh}=0.96)$. Its simple ribs are rectiradiate or slightly rursiradiate, fine, and uniform without bifurcation. The number of ribs per quarter whorl is 21 . 
Discussion: All specimens resemble the original drawing by Ooster (1860) in the number and shape of ribs.

Occurrences: Lower Cretaceous (Barremian); Switzerland.

Genus Hamulinites Thieuloy, 1966

Hamulinites sp.

Fig. 9Y, Z.

Material: 1 shell fragment (NMSG Coll. KT. ASW_0048).

Locality and horizon: Altmann-Sattel, Südwest-Seite I, Altmann Member, uppermost Hauterivian-upper lower Barremian.

Description: NMSG (Coll. KT. ASW_0048) measures $44 \mathrm{~mm}$ in diameter. Its conch is ancyloceraticonic and slightly curved. There are 16 ribs on the fragment. The whorl cross section is slightly higher than wide $(\mathrm{ww} / \mathrm{wh}=0.89)$.

Discussion: Its ancyloceraticonic conch morphology distinguishes this genus from Leptoceratoides and Orbignyceras.

Occurrence: Lower Cretaceous (Barremian; for the genus).

Superfamily Turrilitaceae Gill, 1871

Family Anisoceratidae Hyatt, 1900

Genus Anisoceras Pictet, 1854

Anisoceras armatum (Sowerby, 1817)

Figs. 9AI, 10F, K, L.

Synonymy: See Kennedy and Latil (2007).

Holotype: Hamites armatus Sowerby, 1817; p. 153, pl. 168.

Material: 6 shell fragments (NMSG Coll. PK. 7.C.07.05, 7.C.07.11, 7.C.13.25, 7.C.15.14, NMSG Coll. KT. HW-A-0010, NA-K-0001). 
Locality and horizon: Hinterwinden-Hornwald (Hinter Gräppelen) (NMSG Coll. PK.

7.C.15.14, NMSG Coll. KT. HW-A-0010), Neuenalp-Kamm (NMSG Coll. KT. NA-K-0001), Tal-Wänneli (NE Neuenalpspitz; NMSG Coll. PK. 7.C.07.05, 7.C.07.11), Säntis, GasthausHang (NMSG Coll. PK. 7C.13.25), Kamm Bed, uppermost Albian-lowermost Cenomanian. Description: NMSG (Coll. PK. 7.C.07.11) is a straight shaft with a length of $56 \mathrm{~mm}$. The whorl section is rounded $(\mathrm{ww} / \mathrm{wh}=0.96)$ with a whorl height of $24 \mathrm{~mm}$. Its ornament consists of looped and rursiradiate ribs. Thick, strong and tuberculated ribs are intercalated by two or three fine, non-tuberculated and blunt ribs.

Discussion: See Kennedy and Latil (2007).

Occurrence: Lower-Upper Cretaceous (upper Albian-lower Cenomanian); England, Spain, France, Belgium, Germany, Switzerland, Hungary, Romania, Serbia, India, Angola, Mozambique, South Africa (KwaZulu-Natal), USA (Texas).

Anisoceras perarmatum Pictet and Campiche, 1861

Fig. 10G.

Synonymy: See Kennedy and Latil (2007).

Lectotype: Anisoceras perarmatum Pictet and Campiche, 1861; p. 65, pl. 49, fig. 1.

Material: 2 shell fragments (NMSG Coll. PK. 7.C.06.03, NMSG Coll. KT. EB-Ch-0002). Locality and horizon: Ebenalp, Übergang gegen Gartenalp (NMSG Coll. KT. EB-Ch-0002), Tal W (NE Neuenalpspitz; NMSG Coll. PK. 7.C.06.03), Kamm Bed, uppermost Albianlowermost Cenomanian.

Description: NMSG (Coll. PK. 7.C.06.03) is a straight shaft with a length of $73 \mathrm{~mm}$. Its whorl section is oval $(\mathrm{ww} / \mathrm{wh}=0.85)$ with a whorl height of $27 \mathrm{~mm}$. Pairs of ribs are connected in the lateral tubercles and fade out dorsally. Intercalated ribs are absent.

Discussion: According to Kennedy et al. (1998), this species differs from A. armatum in having no (or few intercalated) ribs. 
Occurrence: Lower Cretaceous (upper Albian-earliest Cenomanian); England, Spain, France, Germany, Switzerland, Hungary, Romania, Ukraine, Crimea, Caucasus, India, Angola, Mozambique, Nigeria, South Africa (Kwazulu-Natal), USA (Texas).

Anisoceras pseudoelegans (Pictet and Campiche, 1861)

Fig. 10I, J.

Synonymy: See Marcinowski and Wiedmann (1990).

Type: Hamites Saussureanus Pictet, 1847; p. 118, pl. 13.

Material: 7 shell fragments (NMSG Coll. PK. 7.C.02.25, 7.C.15.11, 7.B.23.15, 7.B.23.32, 7.B.25.23, 7.B.26.18, NMSG Coll. UO. 009).

Locality and horizon: Hinterwinden-Hornwald (Hinter Gräppelen; NMSG Coll. PK.

7.C.15.11); Stütze 2 Säntisbahn S (NMSG Coll. PK. 7.C.02.25), Säntis (NMSG Coll. UO. 009), Kamm Bed, uppermost Albian-lowermost Cenomanian; Bergli, Sennwald (NMSG Coll. PK. 7.B.25.23), Stofel, Lenziwis (NMSG Coll. PK. 7.B.26.18), In Ränken, Plona (NMSG Coll. PK. 7.B.23.15, 7.B.23.32), Garschella Formation, Albian.

Description: NMSG (Coll. PK. 7.B.25.23) is a slightly curved shaft with a length of $41 \mathrm{~mm}$. The whorl section is oval $(\mathrm{ww} / \mathrm{wh}=0.89)$ with a whorl height of $17 \mathrm{~mm}$. Its ornament consists of looped and rursiradiate ribs. Tuberculated ribs are intercalated by two or three, very fine ribs. Fine ribs are also present on the dorsum while tuberculated ribs do not occur there.

Discussion: This species is similar to A. armatum, but it has finer ribs.

Occurrence: Lower Cretaceous (upper Albian); England, France, Italy (Sardinia), Switzerland, Hungary, South Africa (KwaZulu-Natal), Japan.

Genus Prohelicoceras Spath, 1925a

Prohelicoceras moutonianum (d'Orbigny, 1850) 
Fig. 10M.

Synonymy: See Marcinowski and Wiedmann (1990).

Type: Helicoceras Moutonianum d'Orbigny, 1850; p. 127, nº 106.

Material: 1 shell fragment (NMSG Coll. PK. 7.B.26.04).

Locality and horizon: Stofel, Lenziwis, Garschella Formation, Albian.

Description: NMSG (Coll. PK. 7.B.26.04) is a helicoidal shell fragment with a maximum whorl height of $20 \mathrm{~mm}$. The whorl section is circular $(\mathrm{ww} / \mathrm{wh}=1.0)$. Its ornament consists of looped and rursiradiate ribs. Tuberculated ribs are intercalated by two or three, very fine ribs.

Fine ribs are present on the dorsum while tuberculated ribs are missing.

Discussion: See Marcinowski and Wiedmann (1990).

Occurrence: Lower Cretaceous (upper Albian); England, France, Switzerland, Poland.

Family Hamitidae Gill, 1871

Genus Hamites Parkinson, 1811

Hamites compressus Sowerby, 1814

Fig. 10R.

Synonymy: See Klein (2015).

Holotype: Hamites compressus Sowerby, 1814; p. 138, pl. 61, figs. 7, 8.

Material: 1 shell fragment (NMSG Coll. PK. 7.C.11.01).

Locality and horizon: Säntis, Gasthaus-Galerie and surrounding, Kamm Bed, uppermost Albian-lowermost Cenomanian.

Description: NMSG (Coll. PK. 7.C.11.01) is a hook-shaped conch fragment with a length of $50 \mathrm{~mm}$ and a whorl height of $22 \mathrm{~mm}$. Its flanks are flattened, while both dorsum and venter are rounded. Its ribs are sharp and more or less straight. There are 6 ribs on a whorl segment equal to whorl height. 
Discussion: This species has a very compressed whorl section. The number of ribs on a whorl segment equal to whorl height is 5 according to Sowerby (1814) and Föllmi (1989b) and 6 to 7 according to Spath (1941).

Occurrence: Lower Cretaceous (upper Albian, lower part of M. inflatum Zone); England, France, Switzerland, Poland, Angola.

Hamites duplicatus Pictet and Campiche, 1861

Fig. 10T.

Synonymy: See Klein (2015).

Lectotype: Hamites duplicatus Pictet and Campiche 1861; p. 391, pl. 14 fig. 7, 9.

Material: 1 shell fragment (NMSG Coll. PK. 7.C.19.04).

Locality and horizon: Lochtem-Grüenböhl, Kamm Bed, uppermost Albian-lowermost Cenomanian.

Description: NMSG (Coll. PK. 7.C.19.04) is a straight conch fragment with a length of 31 $\mathrm{mm}$. The whorl section is slightly oval $(\mathrm{ww} / \mathrm{wh}=0.91)$ with a whorl height of $82 \mathrm{~mm}$. Ribs with a number of 7 in a diameter equal to the whorl height are sharp, very fine, feebly prorsiradiate and attenuated on the dorsum.

Discussion: The number of ribs on a length equal to the whorl height is 7 to 10 (Spath 1941; Gale et al. 1996). For details, see Gale et al. (1996).

Occurrence: Lower-Upper Cretaceous (upper Albian-upper Cenomanian); England, France, Germany, Switzerland, Hungary, Poland, Georgia, Iran, Kazakhstan, Angola, Japan.

Hamites simplex d'Orbigny, 1842

Fig. 10N.

Synonymy: See Klein (2015).

Lectotype: Hamites simplex d'Orbigny 1842; p. 550, pl. 134, figs. 12-14. 
Material: 1 fragment (NMSG Coll. PK. 7.C.13.05).

Locality and horizon: Säntis, Gasthaus-Hang, Kamm Bed, uppermost Albian-lowermost Cenomanian.

Description: NMSG (Coll. PK. 7.C.13.05) is a slightly flexuose shaft with a length of $28 \mathrm{~mm}$.

The whorl section is oval $(\mathrm{ww} / \mathrm{wh}=0.84)$ with a whorl height of $8 \mathrm{~mm}$. Ribs are fine, prorsiradiate and weak on the dorsum. The number of ribs in a diameter equal to its whorl height is 6.

Discussion: See Cecca (2001).

Occurrence: Upper Cretaceous (lower-middle Cenomanian); England, France, Germany, Poland, Daghestan, USA (Western Interior), Australia.

Hamites subvirgulatus (Spath, 1941)

Fig. 10P.

Synonymy: See Klein (2015).

Holotype: Hamites (Stomohamites) subvirgulatus Spath, 1941; p. 645, text-fig. 234a-h.

Material: 1 fragment (NMSG Coll. PK. 7.C.02.07).

Locality and horizon: Stütze 2 Säntisbahn S, Kamm Bed, uppermost Albian-lowermost Cenomanian.

Description: NMSG (Coll. PK. 7.C.02.07) is a gryconic fragment with a length of $35 \mathrm{~mm}$. The whorl section is more or less circular $(\mathrm{ww} / \mathrm{wh}=0.95)$ with a whorl height of $9 \mathrm{~mm}$. Five sharp, fine prorsiradiate ibs are visible on a diameter equal to its whorl heightand are absent on the dorsum.

Discussion: See Gale et al. (1996).

Occurrence: Lower Cretaceous (upper Albian-middle Cenomanian); England, possibly Germany, Switzerland, Italy (Sardinia), Poland, Romania, Angola, Madagascar. 
Hamites virgulatus Brongniart, 1822

Fig. 10S.

Synonymy: See Föllmi (1989b).

Type: Hamites virgulatus Brongniart, 1822; pl. 10, fig. 6.

Material: 3 fragments (NMSG Coll. PK. 7.B.26.13, 7.B.37.13, 7.B.38.01).

Locality and horizon: Chelen-Geren (SW Plona; NMSG Coll. PK. 7.B.37.13), Unter-Hard,

Rüthi SG (NMSG Coll. PK. 7.B.38.01), Stofel, Lenziwis (NMSG Coll. PK. 7.B.26.13),

Garschella Formation, Albian.

Description: NMSG (Coll. PK. 7.B.26.13) is weakly bent with a length of $30 \mathrm{~mm}$. The whorl section is oval $(\mathrm{ww} / \mathrm{wh}=0.86)$ with a height of $12 \mathrm{~mm}$. Ribs are sharp, straight to faintly rursiradiate; there are 4 ribs on a segment equal to its whorl height.

Discussion: Our specimens are similar to the one described in Pictet (1847) in rib spacing and whorl cross section.

Occurrence: Lower-Upper Cretaceous (upper Albian-lower Cenomanian); England, Spain, France, Switzerland, Poland, Italy, Madagascar, Mozambique, USA, Mexico.

Hamites cf. maximus Sowerby, 1814

Fig. $10 \mathrm{H}$.

Synonymy: See Föllmi (1989b).

Type: Hamites maximus Sowerby, 1814; p. 138, pl. 62, fig. 1.

Material: 3 fragments (NMSG Coll. PK. 7.B.25.32, NMSG Coll. KT. HW-A-0013).

Locality and horizon: Bergli, Sennwald (NMSG Coll. PK. 7.B.25.32), Hinterwinden-

Hornwald (Hinter Gräppelen; NMSG Coll. KT. HW-A-0013), Garschella Formation, Albian

Description: NMSG (Coll. KT. HW-A-0013) is a straight shaft, measuring $70 \mathrm{~mm}$. The whorl section is slightly compressed $(\mathrm{ww} / \mathrm{wh}=0.88)$ with a whorl height of $93 \mathrm{~mm}$. Its ribs are relatively blunt and straight. There are 5 ribs on a whorl length equaling whorl height. 
Discussion: This species has a more or less circular whorl section. Its ribs are blunt. The number of ribs in a length equal to whorl height is 6 according to Sowerby (1814) and 4 to 6 according to Spath (1941).

Occurrence: Lower Cretaceous (middle-early upper Albian); England, France, Austria.

Hamites cf. similis (Casey, 1961)

Fig. $10 \mathrm{O}$.

Synonymy: See Klein (2015).

Type: Lytohamites simils Casey, 1961; p. 92.

Material: 2 fragments (NMSG Coll. PK. 7.B.23.28, NMSG Coll. KT. Rä-IR-0009).

Locality and horizon: In Ränken, Plona, Garschella Formation, Albian.

Description: NMSG (Coll. PK. 7.B.23.28) is a hook-shaped conch fragment with a length of $24 \mathrm{~mm}$. The whorl section is slightly oval $(\mathrm{ww} / \mathrm{wh}=0.93)$ with a whorl height of $10 \mathrm{~mm}$. Its ribs are dense, sharp, very fine, and prorsiradiate. There are 9 ribs in a diameter equal to the whorl height.

Discussion: The number of ribs of Spath's (1941) specimen (Hamites (Stomohamites?)

multicostatus; Text-fig. 219i, f) is 9 or 10 in a whorl segment equal to whorl height. Some specimens figured in Föllmi (1989b) appear to have the same number of ribs in a length equal to whorl height. But as Wright and Kennedy (1995) pointed out, following Spath (1941), a separation of the species belonging to the genus Hamites in the Late Albian is doubtful. The difference lies merely in the sharpness and distance of the ribs of small specimens.

Occurrence: Lower Cretaceous (upper Albian); England, Angola.

\section{Hamites sp.}

Fig. 10Q.

Material: 1 fragment (NMSG Coll. KT. CH-O-0001). 
Locality and horizon: Oberrieter Chienberg West (NMSG Coll. KT. CH-O-0001), Kamm Bed, uppermost Albian-lowermost Cenomanian.

Description: NMSG (Coll. KT. CH-O-0001) is a straight shaft with a length of $25 \mathrm{~mm}$. The whorl section is slightly oval (ww/wh $=0.91)$ with a whorl height of $25 \mathrm{~mm}$. Ribs are blunt, widely spaced, and straight. There are 4 ribs on a whorl segment equal to the corresponding whorl height.

Discussion: Spath (1941) mentioned that the ribs of Hamites maximus are blunt and become widely spaced late in ontogeny. Our specimen has a wide whorl interspace and blunt ribs; in these respectes, it is similar to a specimen illustrated by Gauthier (2006: plate 44, fig10). The ribs of our specimens are slightly too widely spaced for the size.

Occurrence: Lower-Upper Cretaceous (for the genus).

Genus Idiohamites Spath, 1925b

Idiohamites cf. dorsetensis Spath, 1926

Fig. 11A, B.

Synonymy: See Klein (2015).

Holotype: Anisoceras alternatus Mantell, Pictet and Campiche, 1861; p. 71, pl. 51, figs. 2, 3. Material: 1 fragment (NMSG Coll. PK. 7.C.02.23).

Locality and horizon: Stütze 2 Säntisbahn S, Kamm Bed, Alpstein.

Description: NMSG (Coll. PK. 7.C.02.23) is a more or less gyroconic conch fragment with a length of $52 \mathrm{~mm}$. The whorl section is compressed and oval (ww/wh $=0.75)$. Coarse and widely spaced ribs are present on the flank, weakening on the dorsum. Two small ventrolateral bullae are present on each rib. There are 4 ribs on a whorl segment equal to the whorl height.

Discussion: The specimen is similar to that figured by Spath (1941). His specimen has some ventrolateral tubercles. Our specimen displays ventrolateral bullae on most of the ribs, but 
they are not conspicuous. Wright and Kennedy (1995) stated that $H$. alternatus is very similar to H. dorsetensis. They argue that Spath (1941) did not provide a clear explanation on how to differentiate between the two species. $H$. dorsetensis, in this respect, may be a synonym of $H$. alternatus.

Occurrence: Lower Cretaceous (upper Albian, M. perinflatum Zone); England, France, Switzerland, Kazakhstan.

Family Turrilitidae Gill, 1871

Genus Mariella Nowak, 1916

Mariella bergeri (Brongniart, 1822)

Fig. 11D, I, K.

Synonymy: See Klein (2015).

Holotype: Turrilites bergeri Brongniart, 1822; p. 399, pl. 7, fig. 3.

Material: 14 fragments (NMSG Coll. PK. 7.C.01.04, 7.C.01.12, 7.C.01.13, 7.C.02.15, 7.C.04.01, 7.C.08.06, 7.C.11.06, 7.C.13.01, 7.C.13.02, 7.C.19.02, NMSG Coll. KT. GS-BS0008, NMSG Coll. UO. 010, 011, 012).

Locality and horizon: Blauschnee-Girenspitz (NMSG Coll. KT. GS-BS-0008), LochtemGrüenböhl (NMSG Coll. PK. 7.C.19.02), Neuenalp-Kamm (NMSG Coll. PK. 7.C.08.06), Tierwis-Stütze 2 Säntisbahn I ((NMSG Coll. PK. 7.C.02.15), Stütze 2 Säntisbahn S (NMSG Coll. PK. 7.C.01.04, 7.C.01.12, 7.C.01.13), Säntis, Gasthaus-Galerie and surrounding (NMSG Coll. PK. 7.C.11.06), Stütze 2 - Girenspitz/Säntis, Weg (NMSG Coll. PK. 7.C.04.01), Säntis, Gasthaus-Hang (NMSG Coll. PK. 7.C.13.01, 7.C.13.02), Säntis (NMSG Coll. UO. 12, 13, 17), Kamm Bed, uppermost Albian-lowermost Cenomanian.

Description: NMSG (Coll. UO. 12) has 4 whorls and measures $147 \mathrm{~mm}$ in maximum measureable diameter. The whorl height of the last whorl is $39 \mathrm{~mm}$. Four obliquely aligned rows of tubercles are present on the flank. They are elongated in the first row from dorsal and 
more or less rounded in the other rows. The fourth row carries the smallest tubercles. The widest space between rows is between the first and second one and the narrowest is between the third and fourth row. The number of tubercles is 14 per half whorl of each row.

Discussion: This is one of the most common heteromorphs of the Alpstein. For a discussion of the species, see Klinger and Kennedy (1978).

Occurrence: Lower Cretaceous (upper Albian); England, Spain, France, Germany, Switzerland, Italy (Sardinia), Hungary, Romania, Iran, Algeria, Madagascar, Morocco, USA (California), Venezuela.

Mariella gresslyi (Pictet and Campiche, 1861)

Fig. 11L.

Synonymy: See Klein (2015).

Syntype: Turrilites gresslyi, Pictet and Campiche, 1861; p. 132, pl. LVII, figs. 11-13.

Material: 1 fragment (NMSG Coll. PK. 7.B.37.20).

Locality and horizon: Chelen-Geren (SW Plona), Garschella Formation, Albian.

Description: NMSG (Coll. PK. 7.B.37.20) measures $39 \mathrm{~mm}$ in diameter with a whorl height of $23 \mathrm{~mm}$. There are four rows of obliquely aligned tubercles, all of which are connected by looped ribs. The lowest row of tubercles is normally covered by the next whorl. There are 7 tubercles per quarter whorl per row.

Discussion: Our specimen resembles the figured specimens in Pictet and Campiche (1861) in having three or four rows of obliquely aligned tubercles, which are connected by ribs.

Occurrence: Lower Cretaceous (upper Albian); England, Switzerland, Hungary, USSR, Angola, Madagascar.

Mariella miliaris (Pictet and Campiche, 1861)

Fig. 11J, O, S-U. 
Synonymy: See Klein (2015).

Type: Holotype, Turrilites Bergeri Brongniart, var. miliaris Pictet and Campiche, 1861; p. 136, pl. 58, fig. 5 .

Material: 9 fragments (NMSG Coll. PK. 7.C.06.04, 7.C.13.19, 7.C.15.12, 7.C.15.33, 7.C.19.01, 7.C.19.09, 7.C.19.10, NMSG Coll. UO. 013, 014).

Locality and horizon: Hinterwinden-Hornwald (Hinter Gräppelen; NMSG Coll. PK.

7.C.15.12, 7.C.15.33), Säntis, Gasthaus-Hang (NMSG Coll. PK. 7.C.13.19), Lochtem-

Grüenböhl (NMSG Coll. PK. 7.C.19.01, 7.C.19.09, 7.C.19.10), Tal W (NE Neuenalpspitz; NMSG Coll. PK. 7.C.06.04), Säntis (NMSG Coll. UO. 013, 014), Kamm Bed, uppermost Albian-lowermost Cenomanian.

Description: NMSG (Coll. UO. 014) has nearly 3 whorls and measures $90 \mathrm{~mm}$ in maximum measurable height. The whorl height of the last whorl is $29 \mathrm{~mm}$. The apical angle is $24^{\circ}$. Four obliquely aligned rows of tubercles are present on the flank. Tubercles of the first row are slightly oval, while the others are subcircular. The tubercles of the 4th row are smaller than the others in size and closer to the adjacent row Discussion: The specimen shows similar characteristics to $M$. bergeri described above. The tubercles are finer and denser than $M$. bergeri: the number of tubercles is 17 for each row per half whorl. For details see Wright and Kennedy (1996).

Occurrence: Lower-Upper Cretaceous (upper Albian-lower Cenomanian, M. mantelli Zone); England, France, Switzerland, Italy (Sardinia), Hungary, Romania, Turkmenistan, Madagascar, South Africa (KwaZulu-Natal).

Genus Ostlingoceras Hyatt, 1900

Ostlingoceras costulatum (Pervinquiére, 1910)

Fig. $11 \mathrm{G}$.

Synonymy: See Wright and Kennedy (1996). 
Lectotype: Turrilites costatus var. costulata Pervinquiére, 1910; p. 50, pl. 14 (5), figs. 6, 7.

Material: 1 fragment (NMSG Coll. PK. 7.C.06.02).

Locality and horizon: Tal W (NE Neuenalpspitz), Kamm Bed, uppermost Albian-lowermost Cenomanian.

Description: NMSG (Coll. PK. 7.C.06.02) has 3 whorls and measures $49 \mathrm{~mm}$ in total height. The whorl height of the last whorl is $24 \mathrm{~mm}$. The apical angle is approximately $26^{\circ}$ (the specimen is somewhat deformed). The whorl section is nearly rectangular with a flat to slightly concave flank. Straight to faintly oblique ribs, which cover the upper and middle flank, are coarse; there are about 26 ribs per whorl carrying two (or three; the second and third rows are almost fused) rows of tubercles on the lower flank. 10 tubercles per quarter whorl are present from which a rib originates.

Discussion: See Wright and Kennedy (1996).

Occurrence: Upper Cretaceous (lower Cenomanian); England, probably Italy, Madagascar, South Africa, Tunisia.

Ostlingoceras puzosianum (d'Orbigny, 1842)

Fig. $11 \mathrm{H}, \mathrm{R}$.

Synonymy: See Klein (2015).

Syntypes: Turrilites puzosianus d'Orbigny, 1842; p. 587, pl. 143, figs. 1, 2.

Material: 7 fragments (NMSG Coll. PK. 7.C.07.03, 7.C.08.01, 7.C.15.18, 7.C.15.32, NMSG

Coll. KT. EB-Ch-0001, HW-A-0053, NMSG Coll. UO. 015).

Locality and horizon: Hinterwinden-Hornwald (Hinter Gräppelen; NMSG Coll. PK.

7.C.15.18, 7.C.15.32, NMSG Coll. KT. HW-A-0053), Ebenalp, Übergang gegen Gartenalp (NMSG Coll. KT. EB-Ch-0001), Tal-Wänneli (NE Neuenalpspitz; NMSG Coll. PK.

7.C.07.03), Neuenalp-Kamm (NMSG Coll. PK. 7.C.08.01), Säntis (NMSG Coll. UO. 015), Kamm Bed, uppermost Albian-lowermost Cenomanian. 
Description: NMSG (Coll. UO. 015) has 2 whorls with a maximum whorl height of $29 \mathrm{~mm}$. Its apical angle measures $17^{\circ}$. The whorl section is rectangular with a flattened flank on which conspicuous obliquely aligned ribs are present. Each rib covers the upper and middle flank. One or two tubercles at the lower flank give rise to a rib. At the lower edge of the imprint zone, two rows of tubercles are present but a part of the lower tubercle row is covered by the next whorl. The number of ribs and tubercles per row in one whorl is 26 and 34 .

Discussion: See Marcinowski and Wiedmann (1990) and Kennedy and Latil (2007).

Occurrence: Lower Cretaceous (upper Albian, M. rostratum and M. perinflatum Zone);

England, Spain, France, Switzerland, Austria, Italy (Sardinia), Hungary, Poland, Romania, Crimea, Caucasus, Georgia, Iran, Turkmenistan, Madagascar.

Genus Hypoturrilites Dubourdieu, 1953

Hypoturrilites gravesianus (d'Orbigny, 1842)

Fig. 11E.

Synonymy: See Klein (2015).

Type: Turrilites Gravesianus d'Orbigny, 1842; p. 596, pl. 144, figs. 3, 4, 5.

Material: 1 fragment (NMSG Coll. PK. 7.C.15.19).

Locality and horizon: Hinterwinden-Hornwald (Hinter Gräppelen), Kamm Bed, uppermost Albian-lowermost Cenomanian.

Description: NMSG (Coll. PK. 7.C.15.19) has a whorl with a maximum whorl height of 27 $\mathrm{mm}$. The whorl cross section is broadly rounded. The tubercles of the first row are the largest and sharp, occupying half of the flank. The other tubercles, two of which are almost fused, are conical and rounded on the top. There are 7 tubercles per half whorl in the first row, while in the lower rows, there are 16 per half whorl.

Discussion: See Wright and Kennedy (1996). 
Occurrence: Upper Cretaceous (lower Cenomanian, M. mantelli Zone); England, France, Germany, Kazakhstan, Turkmenistan, South Africa (KwaZulu-Natal), USA (Gulf coast), Argentina, Japan, Australia.

Hypoturrilites cf. collignoni Wright and Kennedy, 1996

Fig. 11C.

Synonymy: See Wright and Kennedy (1996).

Holotype: Hypoturrilites collignoni Wright and Kennedy, 1996; p. 376, pl. 99, fig. 33.

Material: 2 fragments (NMSG Coll. PK. 7.C.01.14, 7.C.13.41).

Locality and horizon: Tierwis-Stütze 2 Säntisbahn I (NMSG Coll. PK. 7.C.01.14), Säntis, Gasthaus-Hang (NMSG Coll. PK. 7.C.13.41), Kamm Bed, uppermost Albian-lowermost Cenomanian.

Description: NMSG (Coll. PK. 7.C.01.14) has 2 whorls and measures $40 \mathrm{~mm}$ in total height. The whorl height of the last whorl is $11 \mathrm{~mm}$. The apical angle is $25^{\circ}$. Its whorl section is almost rectangular. There are four obliquely aligned rows of tubercles, three of which are subequidistant while the fourth one is situated closer to the third one. The tubercles of the first row are slightly elongate while the others are conical to subspherical. All tubercles have a flat top. The number of tubercles in the first row is lower ( 8 per half whorl) than in the other rows (10 per half whorl). NMSG (Coll. PK. 7.C.13.41) has 2 whorls with a maximum height of 42 $\mathrm{mm}$. The apical angle is $19^{\circ}$. The whorl cross section is nearly rectangular with a flat to slightly concave flank. There are four obliquely aligned rows of tubercles. The third and fourth tubercles are situated closer to each other and are slightly smaller than those of the other two rows. The tubercles in the first row are elongated while the other ones are rounded. The number of tubercles in the first row is lower (6 per half whorl) than in the other rows ( 8 per half whorl).

Discussion: See Wright and Kennedy (1996). 
Occurrence: Upper Cretaceous (lower Cenomanian, M. mantelli Zone, Neostlingoceras carcitanense Subzone); England, France, Switzerland, Madagascar.

Genus Pseudhypoturrilites Cooper, 1999

Pseudhypoturrilites cf. sharpei (Wright and Kennedy, 1996)

Fig. 11F.

Synonymy: See Wright and Kennedy (1996).

Holotype: Hypoturrilites sharpei Wright and Kennedy 1996; p. 378, pl. 100, fig. 15.

Material: 1 fragment (NMSG Coll. PK. 7.C.15.34).

Locality and horizon: Hinterwinden-Hornwald (Hinter Gräppelen), Kamm Bed, uppermost Albian-lowermost Cenomanian.

Description: NMSG (Coll. PK. 7.C.15.34) has a maximum whorl height of $16 \mathrm{~mm}$. The whorl section is rectangular. Four obliquely aligned and somewhat pointed tubercles are present, between which weak ribs are developed. The first and second rows of tubercles are larger than the others, occupying two thirds of the flank. There are 11 tubercles per half whorl in the first row, while in the lower rows, there are 13.

Discussion: See Wright and Kennedy (1996).

Occurrence: Upper Cretaceous (lower Cenomanian, M. mantelli Zone, Neostlingoceras carcitanense Subzone); England.

Genus Neostlingoceras Klinger and Kennedy, 1978

Neostlingoceras carcitanense (Matheron, 1842)

Fig. 11P.

Synonymy: See Klein (2015).

Holotype: Turrilites tuberculatus Matheron 1842; p. 267, pl. 41, fig. 4.

Material: 2 conchs (ETHZ 10424, NMSG Coll. PK. 7.C.13.34). 
Locality and horizon: Gartenalp (ETHZ 10424), ?uppermost Albian-lowermost Cenomanian;

Säntis, Gasthaus-Hang (NMSG Coll. PK. 7.C.13.34), Kamm Bed, uppermost Albianlowermost Cenomanian.

Description: ETHZ 10424 has a maximum whorl height of $14 \mathrm{~mm}$ with a rectangular whorl section. Two rows of tubercles are present, the upper of which with conical tubercles. These tubercles are located just above the middle flank while the lower row carries slightly elongated tubercles just above the whorl suture. The numbers of tubercles in the upper and lower rows are 7 and 12 per half whorl, respectively. NMSG (Coll. PK. 7.C.13.34) measures $63 \mathrm{~mm}$ in maximum diameter. Its whorl section is rectangular with flattened flanks. Two rows of tubercles are present on the middle and lowest part of the flank. The numbers of tubercles in the upper and lower rows are 7 and 13 per half whorl, respectively.

Discussion: See Wright and Kennedy (1996).

Occerrence: Upper Cretaceous (lower Cenomanian); England, France, Germany, Poland, Kazakstan, Iran, India, Madagascar, South Africa (KwaZulu-Natal), USA (Gulf coast), Japan.

Genus Turrilitoides Gill, 1871

Turrilitoides intermedius (Pictet and Campiche, 1861)

Fig. 11M.

Synonymy: See Klein (2015).

Lectotype: Turrilites intermedius Pictet and Campiche, 1861; p. 127, pl. 57, fig. 12.

Material: 1 fragment (NMSG Coll. KT. SG-AG-0002).

Locality and horizon: Säntis, Gasthaus-Hang, Kamm Bed, uppermost Albian-lowermost Cenomanian.

Description: NMSG (Coll. KT. SG-AG-0002) has a maximum whorl height of $16 \mathrm{~mm}$. Its whorl section is rounded and higher than wide. 15 non-tuberculate ribs per demi whorl are present. 
Discussion: See Marcinowski and Wiedmann (1990).

Occurrence: Lower Cretaceous (upper Albian); England, France, Hungary, Poland, Switzerland, South Africa (KwaZulu-Natal).

Family Baculitidae Meek, 1876

Genus Lechites Nowak, 1908

Lechites gaudini (Pictet and Campiche, 1861)

Fig. 9S, T, AF.

Synonymy: See Kennedy and Latil (2007).

Type: Baculites gaudini Pictet and Campiche, 1861, p. 112, pl. 55, figs. 5-7.

Material: 5 fragments (NMSG Coll. PK. 7.B.20.06, 7.C.02.09, 7.C.13.07, 7.C.14.03, NMSG

Coll. UO. 007).

Locality and horizon: Lochtem-Grüenböhl (NMSG Coll. PK. 7.C.13.07), Stütze 2 Säntisbahn S (NMSG Coll. PK. 7.C.02.09), Hinterwinden (Hinter Gräppelen; NMSG Coll. PK.

7.C.14.03), Säntis, (NMSG Coll. UO. 007), Kamm Bed, uppermost Albian-lowermost Cenomanian; Schlatt (above Rüthi SG; NMSG Coll. PK. 7.B.20.06), Garschella Formation, Albian.

Description: NMSG (Coll. PK. 7.C.14.03) has a straight shaft, which has a diameter of 38 $\mathrm{mm}$ with a slightly compressed whorl section $(\mathrm{ww} / \mathrm{wh}=0.93)$. Its ornament is composed of prorsiradiate ribs, which fade out dorsally. There are 5 ribs in a diameter equal to whorl height. NMSG (Coll. PK. 7.C.13.42) is a straight shaft of $32 \mathrm{~mm}$ diameter with a compressed whorl section $(w w / w h=0.87)$. Its conch is smooth with very oblique ribs. There are two ribs in a diameter equal to whorl height.

Discussion: NMSG (Coll. PK. 7.C.13.42) is a variant with less dense ribbing, previously referred to as L. raricostatus. See Cooper and Kennedy (1977). 
Occurrence: Lower-Upper Cretaceous (upper Albian, M. pricei Zone-Lower Cenomanian); England, France, Germany, Switzerland, Italy (Sardinia), Hungary, Romania, India, Algeria, Madagascar, South Africa (KwaZulu-Natal), Mexico, Japan.

Genus Sciponoceras Hyatt, 1894

Sciponoceras baculoides (Mantell, 1822)

Fig. 9AG.

Synonymy: See Kennedy et al. (2011).

Lectotype: Sciponoceras baculoides Mantell; Kennedy, 1971, p. 9, pl. 1, figs. 12-18.

Material: 1 conch fragment (NMSG Coll. PK. 7.C.13.06).

Locality and horizon: Säntis, Gasthaus-Hang, Kamm Bed, uppermost Albian-lowermost Cenomanian.

Description: NMSG (Coll. PK. 7.C.13.06) is a fragment, measuring $27 \mathrm{~mm}$ in maximum length. The whorl section is slightly compressed $(w w / w h=0.94)$. Ribs are oblique and unconspicuous. There is one strong constriction with a dorsal sinus. It appears that there was a second constriction where the specimen broke. There are 6 ribs between these two constrictions.

Discussion: See Wright and Kennedy (1995).

Occurrence: Upper Cretaceous (Cenomanian); France, Belgium, Germany, Switzerland, Hungary, Poland, Romania, Russia, India, Madagascar, South Africa (KwaZulu-Natal), USA (California, Texas), Japan, New Zealand.

Sciponoceras roto Cieśliński, 1959

Fig. 9AJ.

Synonymy: See Kennedy et al. (2011).

Lectotype: Sciponoceras roto Cieśliński, 1959; p. 39, 75, 89, text-Fig. 10(2). 
Material: 1 fragment (NMSG Coll. UO. 008).

Locality and horizon: Säntis, Kamm Bed, uppermost Albian-lowermost Cenomanian).

Description: NMSG (Coll. UO. 008) is a straight shaft measuring $93 \mathrm{~mm}$ in length. Its conch is gradually expanding with a slightly oval whorl section $(\mathrm{ww} / \mathrm{wh}=0.93)$. There are 6 oblique $\left(45-50^{\circ}\right)$ and weak ribs on a whorl segment equal to the whorl height. There is only one oblique and blunt constriction preserved in this specimen.

Discussion: See Wright and Kennedy (1995).

Occurrence: Upper Cretaceous (Cenomanian, probably restricted to the lower Cenomanian); England, France, Germany, Poland, Kazakhstan, Tunisia.

Superfamily Scaphitaceae Gill, 1871

Family Sacphitidae Gill, 1871

Subfamily Scaphitinae Gill, 1871

Genus Scaphites Parkinson, 1811

Scaphites cf. simplex (Jukes-Browne, 1875)

Fig. 11X, Y.

Synonymy: See Wiedmann (1965).

Type: Scaphites Meriani var. simplex Juke-Browne, 1875; p. 287, pl. 14, fig. 3.

Material: 3 fragment of body chamber (NMSG Coll. PK. 7.C.13.20, STG_14, NMSG Coll. KT. Sä-GS-0020).

Locality and horizon: Säntis, Gasthaus-Hang (NMSG Coll. PK. 7.C.13.20), Säntis, Gasthaus Hang, Wannenalp-Schicht (NMSG Coll. KT. Sä-GS-0020), uppermost Albian-lowermost Cenomanian; Unknown (STG_14).

Description: NMSG (Coll. KT. Sä-GS-0020) is a straight shaft with a weathered normally coiled part, and most of the following U-shaped hook, measuring $50 \mathrm{~mm}$ in length. The 
normally coiled part is globose. The body chamber is compressed with a broad and flat venter. The ribs on the body chamber are very fine; these ribs carry 7 pairs of tubercles.

Discussion: Spath (1937) described this species as a member of Scaphites with nearly involute, globose initial whorls and a depressed body chamber. Mainly the body chamber is preserved in our specimen, showing the depressed whorl section. Cooper (1990) considered that Sc. meriani Pictet and Campiche, 1861 and Sc. simplex Jukes Browne, 1865 are synonyms of $H$. hugardianus d'Orbigny, 1842, showing the characteristic morphological intraspecific variation of the species. By contrast, Wright and Kennedy (1996) considered Sc. hugardianus as a nomen dubium, stating that the main difference between the above mentioned species is the suture line course. We tentatively regard $S c$. simplex and $S c$. hugardianus as independent and valid species until a thorough revision has been carried out and published.

Occurrence: Lower Cretaceous (upper Albian); England, Spain, France, Germany, Switzerland, Iran, Madagascar.

Scaphites hugardianus d'Orbigny 1842

Fig. 11N.

Synonymy: See Cooper (1990).

Lectotype: Scaphites hugardianus d'Orbigny, 1842; p. 521, 525.

Material: 1 phragmocone (NMSG Coll. PK. 7.C.07.09) and 1 conch (NMSG Coll. UO. 016). Localitiy: Tal-Wänneli (NE Neuenalpspitz; NMSG Coll. PK. 7.C.07.09), Säntis (NMSG Coll. UO. 016), Kamm Bed, uppermost Albian-lowermost Cenomanian.

Description: NMSG (Coll. UO. 016) is an adult specimen with lappet at the aperture, measuring $23 \mathrm{~mm}$ in diameter. Its phragmocone is involute with a completely closed umbilicus. The whorl section is depressed with a very broadly rounded venter. Its flank is rounded with lateral tubercles between which 2-3 fine ribs are present on the body chamber. 
The ribs are very dense and cross the venter. The number of ribs in a distance equal to the whorl width is approximately 17.

Discussion: As mentioned previously, some morphological characters of this species overlap with those of S. simplex. The main difference (except their suture lines) appears to be in their tuberculation. S. hugardianus retains pericodic tubercles on the body chamber. Furthermore $S$. hugardianus reaches only a small adult size.

Occurrence: Lower Cretaceous (upper Albian-?lower Cenomanian); England, Spain, France, Switzerland, Italy (Sardinia), Hungary, Algeria, Madagascar.

Genus Eoscaphites Breistroffer, 1947

Eoscaphites subcircularis (Spath, 1937)

Fig. 11Q.

Synonymy: See Wiedmann (1965). The species was also mentioned by Gale et al. (2011). Type: Scaphites subcircularis Spath, 1937; p. 501, text-fig. 175e, pl. 57, figs. 10-12. Material: 1 fragment (ETHZ 10425) and 1 complete conch (NMSG Coll. PK. 7.B.26.02). Locality and horizon: Stofel,Lenziwis (NMSG Coll. PK. 7.B.26.02), ?St. Fähnern, Appenzell (ETHZ 10425), Garschella Formation, Albian.

Description: NMSG (Coll. PK. 7.B.26.02) is a complete conch, measuring $22 \mathrm{~mm}$ in maximum length and $10 \mathrm{~mm}$ in diameter of the regularly coiled part. The latter part of the conch, which is followed by the straight body chamber, is subinvolute (uw/dm $=0.29$ ). The straight shaft of the body chamber ends with a U-shaped hook whose fine and radiate ribs cover the entire conch; these can be single or bifurcating.

Discussion: See Wiedmann (1965).

Occurrence: Lower Cretaceous (upper Albian, M.pricei Zone); England, France, Austria, Madagascar. 
Suborder Lytoceratina Hyatt, 1889

Superfamily Tetragonitaceae Hyatt, 1900

Family Tetragonitidae Hyatt, 1900

Genus Tetragonites Kossmat, 1895

Tetragonites jurinianus jurinianus (Pictet, 1847)

Figs. 9Q, R.

Synonymy: See Klein et al. (2009).

Holotype: Ammonite Jurinianus Pictet, 1847; p. 297, pl. 3, figs. 3a-c.

Material: 3 conchs (NMSG Coll. PK. 7.C.01.09, 7.C.11.03, 7.C.15.15).

Locality and horizon: Säntis, Gasthaus-Galerie and surrounding (NMSG Coll. PK. 7.C.11.03),

Tierwis-Stütze 2 Säntisbahn I (NMSG Coll. PK. 7.C.01.09), Hinterwinden-Hornwald (Hinter

Gräppelen; NMSG Coll. PK. 7.C.15.15), Kamm Bed, uppermost Albian-lowermost

Cenomanian.

Description: NMSG (Coll. PK. 7.C.11.03) measures $39 \mathrm{~mm}$ in diameter. Its conch is thickly discoidal $(\mathrm{ww} / \mathrm{dm}=0.59)$ and subinvolute $(\mathrm{uw} / \mathrm{dm}=0.22)$. The whorl section is rectangular and wider than high $(\mathrm{ww} / \mathrm{wh}=1.24)$. Only some parts of saddles are preserved.

Discussion: Our specimen with the above mentioned measurements fits well with specimens shown in figure 6 of Cooper and Kennedy (1979).

Occurrence: Lower-Upper Cretaceous (upper Albian-lower Cenomanian); France, Italy (Sardinia), Switzerland, Poland, India, Angola, Madagascar, Canada (British Columbia), USA (Alaska, California, Florida).

Tetragonites timotheanus timotheanus (Pictet, 1847)

Fig. 11AJ, AK.

Synonymy: See Klein et al. (2009).

Lectotype: Ammonites timotheanus Pictet, 1847; p. 295, pl. 3, figs. 1a-c. 
Material: 1 conch (NMSG Coll. PK. 7.B.23.03).

Locality and horizon: In Ränken, Plona, Garschella Formation, Albian.

Description: NMSG (Coll. PK. 7.B.23.03) measures $26 \mathrm{~mm}$ in diameter. The conch is

discoidal $(\mathrm{ww} / \mathrm{dm}=0.46)$ and subevolute $(\mathrm{uw} / \mathrm{dm}=0.35)$. Its whorl section is rectangular and wider than high $(\mathrm{w} w / \mathrm{wh}=1.2)$. There are three constrictions per whorl.

Discussion: This species is characterized by a wide umbilicus and trapezoidal whorl sections.

For a detailed description, see Wiedmann (1962).

Occurrence: Lower Cretaceous (middle Albian-lower Cenomanian); England, Spain, France, Germany, Hungary, Iran, India, Egypt, Madagascar.

Genus Kossmatella Jocob, 1907

Kossmatella agassiziana (Pictet, 1847)

Fig. $11 \mathrm{AH}, \mathrm{AI}$.

Synonymy: See Scholz (1979).

Type: Ammonite Agassizianus Pictet, p. 303, pl. 4, fig. 3a-c.

Material: 2 conchs (NMSG Coll. PK. 7.C.14.02, 7.C.13.29).

Locality and horizon: Hinterwinden (Hinter Gräppelen; NMSG Coll. PK. 7.C.14.02), Säntis, Gasthaus-Hang (NMSG Coll. PK. 7.C.13.29), Kamm Bed, uppermost Albian-lowermost Cenomanian.

Description: NMSG (Coll. PK. 7.C.14.02) measures $29 \mathrm{~mm}$ in diameter. Its conch is thinly discoidal $(\mathrm{ww} / \mathrm{dm}=0.38)$ and subinvolute $(\mathrm{uw} / \mathrm{dm}=0.28)$. The whorl section is slightly rounded and higher than wide $(\mathrm{ww} / \mathrm{wh}=0.81)$. There are 8 bulges with very fine ribs on the flank per half a whorl.

Discussion: The ornamentation is like that of $K$. muhlenbecki. Both our specimens have a narrower umbilicus than the specimens described as K. muhlenbecki in Wiedmann and Dienni $(1968 ; \mathrm{uw} / \mathrm{dm}=0.40-0.42)$. As mentioned above, the definition of this species is not yet clear. 
We tentatively regard this species as involute variant of Kossmatella. For details see Scholz (1979).

Occurrence: Lower Cretaceous (middle-upper Albian); Spain, France, Switzerland, Italy, Hungary, Serbia, Crimea, Caucasus, Azerbaijan.

Kossmatella muhlenbecki (Fallot, 1885)

Fig. $11 \mathrm{AB}, \mathrm{AC}$.

Synonymy: See Klein et al. (2009). The species was also mentioned by Gale et al. (2011).

Type: Ammonites (Desmoceras) Muhlenbecki Fallot, 1885; p. 233, pl. IV, fig. 1a.

Material: 1 conch (NMSG Coll. PK. 7B.37.31).

Locality and horizon: Chelen-Geren (SW Plona), Garschella Formation, Albian.

Description: NMSG (Coll. PK. 7B.37.31) measures $37 \mathrm{~mm}$ in diameter. Its conch is thinly discoidal $(\mathrm{ww} / \mathrm{dm}=0.33)$ and subevolute $(\mathrm{uw} / \mathrm{dm}=0.40)$. The whorl cross section is subrectangular (flattened venter and flanks) and slightly higher than wide (ww/wh $=0.91)$. There are 16 bulges with very fine ribs on the flank in the outermost whorl.

Discussion: Scholz (1979) discussed the taxonomy of Kossmatella. He considered that some Kossmatella species (K. muhlenbecki, K. romana, K. schwindewolfi, K. oosteri and $K$. agassiziana) could be synonymized. This may be reasonable because previous studies often overlooked or ignored intraspecific variability. However, our materials do not permit to solve the problem because of the low number of specimens and the moderate preservation. See also Wiedmann and Dienni (1968) for a further discussion.

Occurrence: Lower Cretaceous (middle-upper Albian); Spain, France, Italy (Sardinia), Hungary.

Familiy Schloenbachiidae Parona and Bonarelli, 1897

Genus Schloenbachia Neumayr, 1875 
Schloenbachia varians (Sowerby, 1817)

Fig. 9AK, AL.

Synonymy: See Wright and Kennedy (2015).

Lectoype: Ammonites varians Sowerby, 1817: p. 169, pl. 176, uppermost figure.

Material: 1 eroded conch (NMSG Coll. UO. 018).

Locality and horizon: Säntis, Kamm Bed, uppermost Albian-lowermost Cenomanian.

Description: NMSG (Coll. UO. 018) measures $81 \mathrm{~mm}$ in diameter. Its conch is sub-involute (uw/dm $=0.27$ ). The whorl section appears compressed, although one side is not preserved. The flank is nearly flat to widely rounded with strongly developed ribs on which umbilical, lateral and ventrolateral tubercles are present. Umbilical tubercles give rise to 1 or 2 ribs. The number of ribs per half whorl is 12 . A distinct keel is present.

Discussion: See Wright and Kennedy (2015).

Occurrences: Upper Cretaceous (Cenomanian); England, Germany, Switzerland, Iran, Greenland.

Suborder Phylloceratina Arkell, 1950

Superfamily Phyllocerataceae Zittel, 1884

Family Phylloceratidae Zittel, 1884

Subfamily Phylloceratinae Zittel, 1884

Genus Phylloceras Suess, 1865

Subgenus Hypophylloceras Salfeld, 1924

Phylloceras (Hypophylloceras) velledae velledae (Michelin, 1834)

Fig. 11Z, AA.

Synonymy: See Kennedy and Fatmi (2014).

Neotype: Phylloceras (Hypophylloceras) velledae Wiedmann, 1964; p. 209, pl. 11, fig. 1, pl. 13, fig. 4, pl. 21, fig.4, text-fig. 49a, b. 
Material: 1 conch (NMSG Coll. PK. 7.C.02.04).

Locality and horizon: Stütze 2 Säntisbahn S, Kamm Bed, uppermost Albian-lowermost Cenomanian.

Description: NMSG (Coll. PK. 7.C.02.04) measures $38 \mathrm{~mm}$ in diameter. Its conch is thinly discoidal $(\mathrm{ww} / \mathrm{dm}=0.37)$ and involute $(\mathrm{uw} / \mathrm{dm}=0.08)$. The whorl section is compressed $(\mathrm{ww} / \mathrm{wh}=0.64)$ with nearly flat flanks and a rounded venter.

Discussion: See Kennedy and Klinger (1977) and Joly (2000).

Occurrence: Lower-Upper Cretaceous (middle Aptian-Cenomanian); Spain (the Baleric Islands), France, Italy, Switzerland, AustriaHungary, Romanian, Algeria, Egypt, Madagascar, Mozambique, South Africa (Kwazulu-Natal), Tunisia, Pakistan, USA (California).

Subgenus Gorethophylloceras Collignon, 1949

Gorethophylloceras subalpinum (d'Orbigny, 1841)

Fig. 11AF, AG.

Synonymy: See Joly (2008). The species was also mentioned by Matrion (2010).

Type: Lectotype Ammonites alpinus d'Orbigny, 1841; p. 283, pl. 83, figs. 1-3.

Material: 2 conchs (NMSG Coll. PK. 7.B.20.21, 7.B.20.75).

Locality and horizon: Schlatt (above Rüthi SG), Garschella Formation, Albian.

Description: NMSG (Coll. PK. 7.B.20.21) measures $32 \mathrm{~mm}$ in diameter. Its conch is moderately discoidal $(\mathrm{ww} / \mathrm{dm}=0.47)$ and involute $(\mathrm{uw} / \mathrm{dm}=0.09)$ with a compressed whorl section $(\mathrm{ww} / \mathrm{wh}=0.79)$ with broadly rounded flanks and a rounded venter.

Discussion: See Joly (2008).

Occurrence: Lower Cretaceous (upper Aptian-upper Albian); France.

Family Ancyloceratidae Gill, 1871

Subfamily Douvilleiceratinae Parona and Bonarelli, 1897 
Genus Douvilleiceras Grossouvre, 1894

Douvilleiceras sp.

Fig. 9G, H.

Material: 3 fragments (NMSG Coll. PK. 7.B.42.12, 7.B.42.13, 7.B.42.14).

Locality and horizon: Bergli Nord, Sennwald, Garschella Formation, Albian.

Description: NMSG (Coll. PK. 7.B.42.14) measures $20 \mathrm{~mm}$ in maximum measurable conch diameter. Its whorl section is much wider than high. There are thick ribs on which 4 simple tubercles are situated. NMSG (Coll. PK. 7.B.42.13) has a diameter of $29 \mathrm{~mm}$. Its whorl section is wider than high $(\mathrm{ww} / \mathrm{wh}=1.35)$. Only 3 ribs are preserved, which carry strong ventrolateral tubercles with 2 grooves each.

Discussion: Douvilleiceras changes its ornamention throughout ontogeny. At an early ontogenetic stage, some species have a quite similar ornamentation, which is not distinguishable. See Casey (1962) for details.

Occurrence: Lower Cretaceous (lower Albian-middle Albian; for the genus).

\section{Discussion}

\subsection{Time-averaging}

In palaeoecological studies, time-averaging is a major problem (Kidwell and Bosence, 1991). Condensation is often linked with environmental changes, which are too rapid to become well-documented in the sedimentary record. This is caused by the low sediment accumulation rate or currents which reduce the sedimentation (Lukeneder et al., 2012). Bearing these problems in mind, our fossil assemblages from the Altmann Member, the Garschella Formation, and particularly the Kamm Bed do not represent a single local community. This means that the faunules examined from these units may include a few successive assemblages from non-uniform environments. However, the changes in faunal composition between 
subsequent faunules are quite distinct and the ecological coherence within these timeaveraged faunules is quite strong (e.g., no or only little mixing of typical shallow water elements (such as corals, sponges and photosynthetic organisms) with characteristic deep water elements (such as cephalopods); a strong domination of one group of modes of life within each faunule). Therefore, we suggest that the overall trends in ecospace utilization and the longterm patterns are recorded well enough to draw conclusions on the major trends in spite of likely faunal mixing; by contrast, subtle and shortterm trends are overprinted by this time-avaraging and thus lost.

\subsection{Palaeoecological changes and palaeoenvironmental factors}

We documented ecological shifts from the Barremian to the early Cenomanian. These shifts in faunal composition through time reflect changes in environmental factors. Here, we discuss the faunal turnovers and related palaeoenvironmental factors with a focus on sea level changes.

\section{Faunule of the Altmann Member (lower Barremian)}

Six different predominant modes of life defined by Bush et al. (2007) were found in the lower Barremian (Nicklesia pulchella and Kotetishvilia compressissima Zones; Fig. 4). The fauna is dominated by nektoplanktonic forms (ammonoids). The lower Barremian strata are rich in clays and marls (Fig. 3). According to Bollinger (1988) and Föllmi et al. (2007), the Tierwis section is composed of mainly heterozoan, partially hemipelagic marl and marly carbonates. Such palaeoenvironments with moderately deep water at the time were probably much more favoured by nektoplanktonic organisms than benthos. The frequent bioturbation of the sediments of the Altmann Member indicates at least temporarily abundant benthic life, of 
which no body fossils are preserved. By contrast, Exogyra and sponges occur in varying numbers. Note that aragonitic elements are more susceptible to dissolution than calcitic elements, which would have affected the preservation potential (Bush and Bambach, 2004).

\section{Faunules of the Schrattenkalk Member (upper Barremian-lower Aptian)}

The analyzed faunules of the upper Barremian are strongly dominated by shallow marine benthos (S1-S7 in Fig. 4; Fig. 12). According to Funk et al. (1993), the upper Drusberg Member and Lower Schrattenkalk Formation are characterized by renewed growth and progradation of a healthy carbonate platform during a shallowing phase. Bonvallet (2015) also reported a shallowing upward trend in facies of the Lower Schrattenkalk Formation and lagoonal faces at its upper part. This is followed by the Rawil Member, which has been deposited during a transgression. During the deposition of the marly beds at the base of the Rawil Member, which contain wood remains, the carbonate platform was emersed occationally (Bonvallet, 2015). These shallow marine settings explain the dominance of benthos in these faunules (photozoan assemblage including, scleractinian corals, rudists, stromatoporoids and larger foraminifera; Masse, 1992; Fig. 12). The macro-faunule S8 in the lower Aptian (Fig. 4, 12) consists only of benthos (rudists). Föllmi et al. (2007) noted that the lithofacies of the Upper Schrattenkalk Formation is similar to that of the Lower Schrattenkalk. Taking this into consideration, it is not surprising that the palaeoenvironment during deposition of layer S8 was quite similar to that of S1-S7.

Föllmi (1986) investigated the palaeogeography of the eastern part of the Helvetic shelf (Vorarlberg) from the Aptian to the Santonian. He documented a transgressive trend from the late Barremian to the Cenomanian (Fig. 13). According to him, the sea level remained low until the early middle Aptian and then started to rise toward the end of Aptian. Our 
palaeoecological data of the layers S1-S8 most likely derive from the time when the palaeoenvironment was still too shallow for nektoplanktonic organisms (probably a few meters water depth) with dominance of reef builders.

\section{Faunule of the Garschella Formation (upper Albian)}

During the early late Albian, nektoplanktonic and nektonic forms (ammonoids and nautilids) regained (Fig. 4; 12). According to Föllmi (1986), the water was slightly deeper than the the fair weather wave base from the early to late Albian (Fig. 13). The faunule of the upper Albian is dominated by nektoplanktonic organisms (Mortoniceras inflatum andM. rostratum Zones), reflecting a sea level, which is higher than that of S1 to S8 horizons that contain exclusively benthos (upper Barremian to lower Aptian).

Faunule of the Kamm Bed (top of the Garschella Formation; uppermost Albian to lowermost

\section{Cenomanian)}

The faunule of the Kamm Bed shows a higher proportion of nektoplanktonic organisms (ammonoids, belemnites and nautilids) than the upper Albian deposits (Fig. 4). This may reflect the onset of a rapid sea level rise in the the Aptian to Albian (Föllmi, 1986; Fig. 13). This rapid sea level rise together with reinforcement of bottom water currents was probably associated with the environmental change that caused the condensed sedimentation of the Kamm Bed (Föllmi, 1986; 1989a).

Faunule at the base of the Seewen Formation (lower Cenomanian) 
The faunule in the layers at the base of the Seewen Formation consists largely of nektoplanktonic organisms (ammonoids and belemnites) with few benthic organisms. This correlates well with the rapid transgression of the latest Albian and a possibly rather moderate transgressive trend, which started in the early Cenomanian (Föllmi, 1986; Fig. 13). In the Tierwis area, the subsequent sedimentary succession of the Seewen Formation contains macrofossils only occasionally. This decrease in fossil content may suggest that (i) either sediment accumulation rates increased, letting the relative fossil abundance diminish, that (ii) somehow, conditions impoverished, sustaining only a lower number of animals or that (iii) the palaeoenvironment lied below the aragonite compensation depth (unlikely).

Reconstructions of habitas of the early late Barremian and late Albian are shown in Fig. 14 and 15. A more detailed investigation of the palaeoecology and alpha-diversity (i.e., richness of taxa in a single locality; Sepkoski, 1988) of the Alpstein is in preparation. Its results might shed more light on such issues.

\section{Conclusions}

1. We investigated the Cretaceous cephalopod associations of the Alpstein (Switzerland) and documented 6 species ( 3 genera) of nautilids and 77 species ( 45 genera) of ammonoids, 29 of which are apparently recorded for the first time from Switzerland (the result section contains a complete list).

2. In the early Barremian, the faunal association of the Alpstein region is dominated by nektoplanktonic forms (ammonoids and nautilids). Considerable changes in ecospace utilisation occurred in the late Barremian and early Aptian where nektoplanktonic elements are largely absent. Then the proportion of nektoplanktonic forms regained, especially during the late Albian (although the stratigraphic resolution is low due to 
condensed sedimentation in parts of the sections). This taxonomic richness is probably caused by condensation linked with the transgressive trend from the early Aptian to the early Albian. Later, nektoplanktonic forms continued to increase in alpha-diversity and became more abundant until the earliest Cenomanian with only few benthic organisms. Analyses with a finer resolution in time are needed to document details of the changes in alpha-diversity of the region.

3. The regional ecological changes from the early Barremian to the early Cenomanian were more or less strongly linked with regional sea level fluctuations. We compared the regional sea level curve for the Cretaceous of Föllmi (1986) with palaeoecological and facies data of the Alpstein. The early Barremian fauna was dominated by nektoplanktonic organism, which probably resulted from the moderately deep water, which is more favourable for nektoplanktonic organisms than a low water deapth. The late Barremian and early Aptian yielded benthos-dominated faunules which correlate well with the low sea level that persisted until the early Aptian. The rising number of nektoplanktonic elements after the late Albian was supposedly related to the transgression (deeper facies) after the early Aptian. The early Cenomanian fauna dominated by nektoplanktonic organisms; this might have resulted from another rapid sea level rise at the end of the Albian.

\section{Acknowledgements}

We greatly appreciate the support by the Swiss National Science Foundation SNF (project No. 200021_149119). We thank Toni Bürgin (St. Gallen) for providing access to the collections of the Naturmuseum St. Gallen and for being a generous host. Urs Oberli (St. Gallen) showed us his great collection of Alpstein fossils and kindly donated some important cephalopod specimens. Additionally, he prepared some of the specimens. We are also grateful to 
Alexander Lukeneder (Vienna) and an anonymous reviewer for their critical comments. 


\section{References}

Arkell, W.J., 1957. Introduction to Mesozoic Ammonoidea. In: Moore, R.C. (Ed.), Treatise on Invertebrate Paleontology, Part L, Mollusca 4, Cephalopoda-Ammonoidea. Geological Society of America and University of Kansas Press.

Amédro, F., Matrion, B., Tomasson, R., Magniez-Jannin, F., Collete, C., 2003. L'Albien supérieur de Vallentigny dans la région stratotypique (Aube, F.): nouvelles données et révision de l'ammonite Mortoniceras (M.) inflatum (J. Sowerby, 1818). Bulletin de la Société géologique de Normandie et des Amis du Muséum du Havre, 90(2), 5-28.

Avram, E., 1995. Representatives of the Family Holcodiscidae Spath, 1924 (Ammonitina) in Rumania. Memorie carta Geologica d'Italia, 51, 11-45.

Bayle, É., 1878. Fossiles pincipaux des terrains Explication de la Carte Géologique de la France: vol. 4, part 1 (atlas). Paris. 158 pl.

Bodin, S., Godet, A., Vermeulen, J., Linder, P., Föllmi, K.B., 2006. Biostratigraphy, sedimentology and sequence stratigraphy of the latest Hauterivian-early Barremian drowning episode of the Northern Tethyan margin (Altmann Member, Helvetic Nappes, Switzerland). Eclogae Geologicae Helvetiae, 99(2), 157-174.

Bolli, H., 1944. Zur Stratigraphie der Oberen Kreide in den höheren helvetischen Decken. Eclogae Geologicae Helvetiae, 37, 216-330.

Bollinger, D., 1988. Die Entwicklung des distalen osthelvetischen Schelfs im Barremian und Früh-Aptian: Drusberg-, Mittagsspitz und Schrattenkalk-Fm. im Vorarlberg und Allgäu.

Dissertation, University of Zurich.

Bonvallet, L., 2015. Evolution of the Helvetic shelf (Switzerland) during the Barremian-early Aptian: paleoenvironmental, paleogeographic and paleoocianographic controlling factors. Dissertation, University of Lausanne. 
Breistroffer, M., 1947. Sur les zones d'ammonites dans l'Albien de France et d'Angleterre.

Travaux du Laboratoire Géologie de la Faculté des Sciences de Grenoble, 26(1946-1947), $17-104$.

Breistroffer, M., 1953. Commentaires taxonomiques. In: Breistroffer, M., Villoutreys O de, Les ammonites albiennes de Peille (Alpes-Maritimes). Travaux du Laboratoire de Géologie de la Faculté des Science de l’Université de Grenoble, 30, 71-74.

Breskovski, S., 1977. Sur la classification de la famille Desmoceratidae Zittel, 1895

(Ammonoidea, Crétacé). Comptes rendus de l'Académie Bulgare des Sciences, 30(6), 891894.

Brongniart, A., 1822. Sur quelques terrains de Crai hors du Bassin de Paris. In: Cuvier, G., Brongniart, A. (Eds.), Description géologique des environs de Paris. 8+428 p.

Busnardo, R., 1970. Torcapella, nouveau genre d'ammonites du Barrémien inférieur. Documents des Laboratories de Géologie Lyon, 37, 85-132.

Bush, A. M., Bambach, R. K., 2004. Did alpha diversity increase during the Phanerozoic? Lifting the veils of taphonomic, latitudinal, and environmental biases. The Journal of Geology, $112,625-642$.

Bush, A.M., Bambach, R.K. Daley, G.M., 2007. Changes in theoretical ecospace utilization in marine fossil assemblages between the mid-Paleozoic and late Cenozoic. Paleobiology, 33(1), 76-97. DOI 10.1666/06013.1

Casey, R. A., 1961. A monograph of the Ammonoidea of the Lower Greensand. Part II. Palaeontological Society, 114, 45-118.

Casey, R. A., 1962. A monograph of the Ammonoidea of the Lower Greensand, Part IV. Palaeontological Society, 116, 217-288.

Casey, R. A., 1966. Palaeontology of the Gault. In: Smart, J.G.O., Bisson, G., Worssam, B.C. (Eds.), Geology of the Country around Canterbury and Folkestone. The Stationery Office Books, London, pp. 102-113. 
Cecca, F., 1997. Late Jurassic and Early Cretaceous uncoiled ammonites: trophism-related evolutionary processes. C. R. Acad, Sci. Paris, Sciences de la terre et des planètes, 325, 629634.

Cecca, F., 2001. The ammonites of the Cenomanian-Turonian transition of Anse de l'Arène section (Cassis, SE France). Geobios, 34(2), 215-223.

Cieśliński, S., 1959. Alb i Cenoman północnego obrzeżenia Gór Świętokrzyskich. Instytut Geologiczny Prace, 28, 1-95.

Collignon, M., 1949. Faunes néocomiennes des couches à Criocères de Belohasifaka (Cercle de Sitampiky) Madagascar. Annales géologiques du Service des Mines, Gouvernement général de Madagascar et Dépendances, Paris 15, 53-85, 6 pls.

Cooper, M.R., 1990. A revision of the Scaphitidae (Cretaceous Ammonoidea) from the Cambridge Greensand. Neues Jahrbuch für Geologie und Paläontologie, Abhandlungen 178, 285-308.

Cooper, M.R., 2012. New names for Late Jurassic-Cretaceous ammonites. Neues Jahrbuch für Geologie und Paläontologie, Abhandlungen, 266, 185-186.

Cooper, M.R., Kennedy, W.J., 1977. A revision of the Baculitidae of the Cambridge Greensand. Neues Jahrbuch für Geologie und Paläontologie, Monatshefte, 11:641-658. Cooper, M.R., Kennedy, W.J., 1979. Uppermost Albian (Stoliczkaia dispar Zone) ammonites from the Angolan littoral. Annals of the South African Museum, 77, 175-308.

Cooper, M.R., Kennedy, W.J., 1987. A revision of the Puzosiinae (Cretaceous ammonites) of the Cambridge Greensand. Neues Jahrbuch für Geologie und Paläontologie, Abhandlungen, $174,105-121$.

Cooper, M.R., 1999. Towards a phylogenetic classification of the Cretaceous ammonites. VII. Turrilitidae. Neues Jahrbuch für Geologie und Paläontologie, Abhandlungen, 213, 1-18.

De Baets, K., Bert, D., Hoffmann, R., Monnet, C., Yacobucci, M.M., Klug, C., 2015: Ammonoid intraspecific variability. In: Klug, C., Korn, D., De Baets, K. Kruta, I. Mapes, R.H. 
(Eds.): Ammonoid paleobiology, Volume I: from anatomy to ecology. Topics in Geobiology, 43, 329-389.

Delamette, M., Kennedy, W.J., 1991. Cenomanian ammonites from the condensed deposits of the Helvetic Domain (Western Alps, France and Switzerland). Journal of Paleontology, 65, $435-465$.

Delanoy, G., Baudouin, C., Gonnet, R., Conte, G., 2012. On the presence of genres Heminautilus SPATH, 1927 and Eucymatoceras SPATH, 1927 (Nautilida, Nautilaceae) in the Lower Barremian Gard (south-eastern France). Annales Muséum d'Histoire Naturelle de Nice, 27, 155-195.

Douvillé, H., 1890. Sur la classification des Cératites de la Craie. Bulletin de la Société Géologique de France, 3, XVIII, 275-292.

Douvillé, H., 1912. Note accompagnant la présentation de l' Atlas de t. iv de l'Explication de la Carte géologique de France de E. Bayle et R. Zeiller. Bulletin de la Société Géologique de France 3(7), 91-92.

Dubourdieu, G., 1953. Ammonites nouvelles des Monts du Mellégue. Bulletin du Service de la Carte Géologique de l'Algerie (serie 1, Paleontologie), 16, 1-76, fig. 1-20, pl. 1-4.

Eugster, H., Forrer, M., Fröhlicher, H., Kempf, T., Schlatter, L., Blaser, R., Funk, H., Langenegger, H., Spoerri, M., Habicht, K., 1982. Säntis (map sheet 1115), Geological Atlas of Switzerland 1:25.000, N. 78. Federal Office of Topography (Swisstopo).

Fallot, J. E., 1885. Étude géologique sur les étages moyens et supérieurs du Terrain Crétacé. Annales des Sciences géologiques 18(1), 262 p. 8 pls.

Fitton, W.H., 1835. Observations on some of the Strata between the Chalk and the Oxford Oolite, in the South-east of England. Transactions of the Geological Society of London, (2) 4, $103-388$. 
Föllmi, K.B., 1986. Die Garschella-und Seewerkalkformation (Aptian-Santonian) im Voralberger Helvetikum und Ultrahelvetikum. Mitteilungen aus dem Geologischen Institut der eidgenössischen Hochschule und der Universität Zürich, Neue Folge 262, 1-391.

Föllmi, K.B., 1989a. Evolution of the mid-Cretaceous triad: platform carbonates, phosphatic sediments, and pelagic carbonates along the northern Tethys margin. Lecture Notes in Earth Sciences, 23, 153 p.

Föllmi, K.B., 1989b. Beschreibung neugefundener Ammonoidea aus der Vorarlberger Garschella Formation (Aptian-Albian). Jahrbuch der Geologischen Bundesanstalt Wien, 132(1), 105-189.

Föllmi, K.B., Ouwehand, P.J., 1987. Garschella Formation und Götzis-Schichten (AptianConiacian): Neue stratigraphische Daten aus dem Helvetikum der Ostschweiz und des Vorarlbergs. Eclogae Geologicae Helvetiae, 80(1), 141-191.

Föllmi, K. B., Bodin, S., Godet, A., Linder, P., Van De Schootbrugge, B., 2007. Unlocking paleo-environmental information from Early Cretaceous shelf sediments in the Helvetic Alps: stratigraphy is the key!. Swiss Journal of Geosciences, 100, 349-369.

Funk, H., 1969. Typusprofile der helvetischen Kieselkalk Formation und der AltmannSchichten. Eclogae Geologicae Helvetiae, 62, 191-203.

Funk, H., Föllmi, K.B., Mohr, H, 1993. Evolution of the Tithonian-Aptian Carbonate Platform along the Northern Tethyan Margin, Eastern Helvetic Alps: Chapter 31. In: Simo, J.A.T., Scott, R.W., Masse, J.P. (Eds), Cretaceous Carbonate Platforms. AAPG Memoir, 56, $387-407$.

Gale, A.S., Kennedy, W.J., Burnett, J.A., Caron, M., Kidd, B.E., 1996. The Late Albian to Early Cenomanian succession at Mont Risou near Rosans (Drôme, SE France): an integrated study (ammonites, inoceramids, planktonic foraminifera, nannofossils, oxygen and carbon isotopes). Cretaceous Research, 17, 515-606. 
Gale, A. S., Bown, P., Caron, M., Crampton, J. S., Crowhurst, S. J., Kennedy, W. J., Petrizzo, M. R., Wray, D. S., 2011. The uppermost Middle and Upper Albian succession at the Col de Palluel, Hautes-Alpes, France: An integrated study (ammonites, inoceramid bivalves, planktonic foraminifera, nannofossils, geochemistry, stable oxygen and carbon isotopes, cyclostratigraphy). Cretaceous Research, 32, 59-130.

Gauthier, H. 2006. Révision critique de la Paléontologie Française d'Alcide d'Orbigny. Volume IV, Céphalopodes Crétacés, 1-292. Leiden: Backhuys.

Giebel, C., 1852. Deutschlands Petrefacten: ein systematisches Verzeichniss aller in Deutschland und den angrenzenden Ländern vorkommenden Petrefacten, nebst Angabe der Synonymen und Fundorte. 706 p. Verlag von Ambrosius Abel, Leipzig.

Gill, T., 1871. Arrangement of the families of mollusks. Smithsonian Miscellaneous Collections 227, xvi +49 p.

Gray, J.E., 1821. A Natural Arrangement of Mollusca, according to their internal stucture. The London Medical Repository 15, 229-239.

Grossouvre, A. de., 1894. Recherches sur la Craie supérieure. Deuxiéme partie: Paléontologie. Les ammonites de la Craie supérieure. Mémoires du Sérvice de la Carte Géologique Détaillée de la France 18993, 264 p. 89, figs., 39 pls. (atlas).

Guex, J., 2006. Reinitialization of evolutionary clocks during sublethal environmental stress in some invertebrates. Earth and Planetary Science Letters 242, 240-253.

Haq, B.U., 2014. Cretaceous eustasy revisited. Global and Planetary Change 113, 44-58.

Hitzel, E., 1902. Sur les fossiles de l'étage Albien recueillis Par MA Guébhard dans la région d'Ecragnolles (A.-M.). Bulletin de la Société géologique de France (serie 4) 2, 874-880.

Hoedemaeker, P., 2013. Genus Pseudothurmannia Spath, 1923 and related subgenera Crioceratites (Balearites) Sarkar, 1954 and C. (Binelliceras) Sarkar, 1977 (Lower Cretaceous Ammonoidea). Revue de Paléobiologie 32, 1-209. 
Hoffmann, R., Lemanis, R., Naglik, C., Klug, C., 2015. Ammonoid buoyancy. Klug, C., Korn, D., De Baets, K. Kruta, I., Mapes, R.H. (Eds.): Ammonoid paleobiology, Volume I: from anatomy to ecology. Topics in Geobiology, 43, pp. 613-648.

Hyatt, A., 1884. Genera of fossil Cephalopods. Proceedings of the Boston Society of Natural History 22, 273-338.

Hyatt, A., 1894. Phylogeny of an acquired characteristic. Proceedings of the American Philosophical Society 32, 349-647.

Hyatt, A., 1889. Genesis of the Arietidae: Smithsonian Contributions to Knowledge 673. Washington, DC, xi, 16.

Hyatt, A., 1900. Cephalopoda: In: Zittel, K.A. v. (Ed.), Textbook of Palaeontology. Eastman, London and New York, pp. 502-592.

Hyatt, A., 1903. Pseudoceratites of the Cretaceous. Monographs of the United States Geological Survey 44, 128-144.

Jacob, C., 1907. Études paléontologiques et stratigraphiques sur la partie moyenne des terrains Crétacés dans les Alpes Françaises et les régions voisines. Annales de I'Université de Grenoble 19(2), 221-534, 6 pls.

Jayet, A., 1929. La variation individuelle chez les ammonites et la diagnose des espéces. Note préliminaire basée sur l'analyse d'Inflaticeras varicosum (SOWERBY). Mémoires de la Société Paléontologique Suisse 49, 1-115.

Joly, B., 2000. Les Juraphyllitidae, Phylloceratidae, Neophylloceratidae (Phyllocerataceae, Phylloceratina, Ammonoidea) de France au Jurassique et au Crétacé. Geobios Mémoire 23, 1204.

Joly, B., Delamette, M., 2008. Les Phylloceratoidea (Ammonoidea) aptiens et albiens du bassin vocontien (Sud-Est de la France). Carnets de Géologie, Brest, Mémoire 4. Jukes-Browne, A.J., 1875. On the relations of the Cambridge Gault and Greensand. Quarterly Journal of the Geological Society 31(1-4), 256-316. 
Kennedy, W.J., 1971. Cenomanian ammonites from southern England. Special Papers in Palaeontology 8, 1-133.

Kennedy, W.J., 1994. Cenomanian ammonites from Cassis, Bouches-du-Rhone, France. Palaeopelagos Special Publication 1, 209-254.

Kennedy, W.J., Klinger, H.C., 1977. Cretaceous faunas from Zululand and Natal, South Africa. The ammonite family Phylloceratidae. Bulletins of the British Museum of Natural History 27(5), 349-380.

Kennedy, W.J., Latil, J.L., 2007. The Upper Albian ammonite succession in the Montlaux section, Hautes-Alpes, France. Acta Geologica Polonica 57(4), 453-478.

Kennedy, W.J., Klinger, H.C., 2013. Cretaceous faunas from Zululand and Natal, South Africa. The ammonite Subfamily Stoliczkaiinae Breistroffer, 1953. African Natural History 9, $1-38$.

Kennedy, W.J., Fatmi A.N., 2014. Albian ammonites from northern Pakistan. Acta Geologica Polonica 64, 47-98.

Kennedy, W.J., Klinger, H.C., 2014. Cretaceous faunas from Zululand and Natal, South Africa. Valdedorsella, Pseudohaploceras, Puzosia, Bhimaites, Pachydesmoceras, Parapuzosia (Austiniceras) and P. (Parapuzosia) of the ammonite subfamily Puzosiinae Spath, 1922. African Natural History 10, 1-46.

Kennedy, W. J., Cobban, W. A., Gale, A. S., 1998. Ammonites from the Weno limestone (Albian) in northeast Texas. American Meseum Novitates 3236, 46 p.

Kennedy, W.J., Jagt, W.M., Amédro, F., Robasyznski, F., 2008. The late Late Albian (Mortoniceras fallax Zone) cephalopod fauna from the Bracquegnies Formation at StrépyThieu (Hainaut, southern Belgium). Geologica Belgica 11, 35-69.

Kennedy, W.J., Amédro, F., Robaszynski, F., Jagt, J. W., 2011. Ammonite faunas from condensed Cenomanian-Turonian sections ('Tourtias') in southern Belgium and northern France. Netherlands Journal of Geosciences 90(2-3), 209-238. 
Kennedy, W.J., Walaszczyk, I., Gale, A.S., Dembicz, K., Praszkier, T., 2013. Lower and Middle Cenomanian ammonites from the Morondava Basin, Madagascar. Acta Geologica Polonica 63(4), 625-655u.

Kennedy, W.J., Klinger, H.C., Lehmann, J., 2015. Cretaceous faunas from Zululand and Natal, South Africa. The ammonite subfamily Mantelliceratinae Hyatt, 1903. African Natural History 11, 1-42.

Kidwell, S.M., Bosence, D.W., 1991. Taphonomy and time-averaging of marine shelly faunas. In: Allison, P.A., Briggs D.E.G. (Eds.), Taphonomy: releasing the data locked in the fossil record. Plenum, New York, pp. 115-209.

Kilian, C.C.C.W., 1889. Sur quelques fossils nouveaux ou peu connus du Crétacé inférieur de la Provence. Bulletin de la Société Géologique de France (séries 3), 16 (1888), 663-691. Kilian, C.C.C.W., 1910. Erste Abteilung: Unterkreide (Palaeocretacicum). Lieferung 2: Das bthyale Palaeocretacicum im südostlichen Frankreich; Valendis-Stufe; Hauterive-Stufe; Barreme-Stufe; Apt-Stufe. In Frech, F. (Ed.), Lethaea Geognostica. II. Das Mesozoicum, Band 3 (Kreide) (1907-1913). Schweizerbart, Stuttgart, pp. 169-288, pls. 1-8. Kilian, C.C.C.W., 1913. Erste Abteilung: Unterkreide (Palaeocretacicum). Lieferung 2: Das bathyale Palaeocretacicum im südostlichen Frankreich: Apt-Stufe: Urgonfacies im südostlichen Frankreich. In Frech, F. (Ed.), Lethaea Geognostica. II. Das Mesozoicum, Band 3 (Kreide) (1907-1913). Schweizerbart, Stuttgart, pp. 289-398.

Klein, J., 2005. Fossilium Catalogus I: Animalia pars 139. Lower Cretaceous Ammonites I:

Perisphinctaceae 1, Himalayitidae, Olcostephanidae, Holcodiscidae, Neocomitidae, Oosterellidae. Backhuys Publishers, Leiden. 484 p.

Klein, J., 2015. Fossilium Catalogus I: Animalia pars 154. Lower Cretaceous Ammonites VIII - Turrilitoidea 1; Anisoceratidae, Hamitidae, Turrilitidae, including the Upper Cretaceous Representatives. Backhuys Publishers, Leiden. 484 p. 
Klein, J., Vašíček Z., 2011. Fossilium Catalogus I: Animalia pars 148. Lower Cretaceous Ammonites V: Desmoceratoidea. Margraf Publishers, Weikersheim. 316 p.

Klein, J., Hoffmann, R., Joly, B., Shigeta, Y., Vašíček Z., 2009. Fossilium Catalogus I:

Animalia pars 146. Lower Cretaceous Ammonites IV: Boreophylloceratoidea,

Phylloceratoidea, Lytoceratoidea, Tetragonitoidea, Haploceratoidea including the Upper

Cretaceous representatives. Backhuys Publishers, Leiden. Margraf Publishers, Weikersheim. $416 \mathrm{p}$.

Klinger, H. C., Kennedy, W. J., 1978. Turrilitidae (Cretaceous Ammonoidea) from South Africa, with a discussion of the evolution and limits of the family. Journal of Molluscan Studies 44, 1-48.

Klug, C., Korn, D., Landman, N.H., Tanabe, K., De Baets, K. \& Naglik, C., 2015. Describing ammonoid shells. In: Klug, C., Korn, D., De Baets, K. Kruta, I., Mapes, R.H. (Eds.):

Ammonoid paleobiology, Volume I: from anatomy to ecology. Topics in Geobiology 43, pp. 3-24, Springer, Dordrecht.

Korn, D., 2010. A key for the description of Palaeozoic ammonoids. Fossil Record 13(1), 512.

Kossmat, F., 1895-1898. Untersuchungen über die Südindische Kreideformation. Beiträge zur Geologie und Paläontologie Österreichs, Ungarens und des Orient 9 (1895), 97-203 (1-107); 10 (1897), 1-46 (108-153); 11 (1898), 89-152 (154-217).

Kummel, B., 1956. Post-Triassic nautiloid genera. Bulletin of the Museum of Comparative Zoology, Harvard, 114, 324-493.

Lehmann, J., Friedrich, O., Luppold, F. W., Weiss, W., Erbacher, J., 2007. Ammonites and associated macrofauna from around the Middle/Upper Albian boundary of the Hannover-Lahe core, northern Germany. Cretaceous Research 28, 719-742. 
Lehmann, J., Ifrim, C., Bulot, L., Frau, C., 2015. Paleobiogeography of Early Cretaceous Ammonoids. In: Klug, C., Korn, D., De Baets, K. Kruta, I., Mapes, R.H. (Eds.): Ammonoid paleobiology, Volume I: from anatomy to ecology. Topics in Geobiology 43, pp. 229-257. Lukeneder, A. 2012. New biostratigraphic data on an Upper Hauterivian-Upper Barremian ammonite assemblage from the Dolomites (Southern Alps, Italy). Cretaceous Research 35, 121.

Lukeneder, A., 2015. Ammonoid Habitats and Life History. In: Klug, C., Korn, D., De Baets, K. Kruta, I., Mapes, R.H. (Eds.): Ammonoid paleobiology, Volume I: from anatomy to ecology. Topics in Geobiology 43, 689-791.

Lukeneder, A., Uchman, A., Gaillard, C., Olivero, D., 2012. The late Barremian Halimedides horizon of the Dolomites (Southern Alps, Italy). Cretaceous Research 35, 199-207.

Mantell, G.A., 1822. The fossils of the South Downs; or illustrations of the geology of Sussex. Lupton Relfe (London). 327 p.

Marcinowski, R., Wiedmann, J., 1990. The Albian ammonites of Poland. Palaeontologia Polonica 50, 3-94.

Masse, J. P., 1992. The Lower Cretaceous Mesogean benthic ecosystems: palaeocologic aspects and palaeobiogeographic implications. Palaeogeography, Palaeoclimatology, Palaeoecology 91, 331-345.

Matheron, P., 1842. Catalogue méthodique et descriptive des corps organisés fossils du Département des Bouches-du-Rhône et lieux circonvoisins. Marseille, 269 p., 41 pls. Matrion, B., 2010. Les ammonites. In: Colleté, C. (Ed.), Stratotype Albien. Muséum national d'Histoire naturelle, Paris; Biotope, Mèze; BRGM, Orléans, Paris, p. 99-193 (314-323: references).

Meek, F.B., 1876. A report on the invertebrate Cretaceous and Tertiary fossils of the Upper Missouri Country. In: Hayden, F.V. (Ed.), Report of the United States Geological and Geographical Surveys of the Territories, vol. 9. 1xiv + 629 p., 84 figs., 45 pls. 
Michelin, J.L.H., 1834. Coquilles fossiles de Gérodot (Aubc). Magazine de Zoologie de Guérin-Méneville, Paris, n 3, classe V, 35 pls.

Michelin, H., 1838. Note sur une argile dépendant du Gault. Mémoires de la Société géologique de France (séries 1) 3, 97-103.

Miller, A.K., Garner, H.F., 1962. Cretaceous nautiloids of New Jersey. In: Richards, H.G. et al. (Eds.), The Cretaceous fossils of New Jersey. Bulletin of the New Jersey Bureau of Geology and Topography, 61(2), 101-111.

Moriya, K., 2015. Evolution of habitat depth in the Jurassic-Cretaceous ammonoids.

Proceedings of the National Academy of Sciences 112, 15540-15541.

Morton, S. G., 1834. Synopsis of the organic remains of the Cretaceous group of the United States. Appendix. Catalogue of the fossil shells of the Tertiary formation of the United States by Timothy A. Conrad. 1-88, App. pp.1-8, Philadelphia.

Mörner, N.A., 1981. Revolution in Cretaceous sea-level analysis. Geology 9, 344-346.

Naglik, C. Rikhtegar, F. Klug, C., 2015. Buoyancy of some Palaeozoic ammonoids and their hydrostatic properties based on empirical 3D-models. Lethaia 49, 3-12. DOI 10.1111/let.12125.

Neumayr, M., 1875. Die Ammoniten der Kreide und die Systematik der Ammonitiden. Zeitschrift der Deutschen Geologischen Gesellschaft 27, 854-942.

Nowak, J., 1908. Untersuchungen über Cephalopoden der oberen Kreide in Polen: I. Teil Genus Baculites Lamarck. Bulletin International de l'Académie des Sciences de Cracovie B, $327-353$.

Nowak, J., 1916. Über die bifiden Loben der oberkretazischen Ammoniten und ihre Bedeutung für die Systematik. Bulletin international de 1 'Académie des Sciences de Cracovie, Classe des Sciences Mathématiques et Naturelles B, 1915, 1-13.

Ooster, W.A., 1860. Catalogue des céphalopodes fossiles des Alpes suisses. IV. Partie:

Céphalopodes tentaculifères, Ammonitides, G. Scaphites. Ancyloceras, Crioceras, Toxoceras, 
Hamites. Ptychoceras, Baculites, Heteroceras, Turrilites, Anisoceras. Neue Denkschriften der Allgemeinen Schweizerischen Gesellschaft der Gesamten Naturwissenschaften 18. 160 p. Orbigny, A. d'. 1840-1842. Paléontologie française. Terrains Crétacés. I: Céphalopodes. Masson, Paris. 662 p. 148pls.

Orbigny, A. d'. 1850. Prodrome de Paléontologie stratigraphique universelle des animaux mollusques \& rayonées faisant suite au cours élémentaire de paléontologie et géologie stratigraphique. Paris, Vol. I, 394 p., vol. II, 427 p.

Ouwehand, P. J., 1987. Die Garschella-Formation ("Helvetischer Gault", Aptian-

Cenomanian) der Churfirsten-Alvier Region (Ostschweiz): Sedimentologie, Phosphoritgenese, Stratigraphie. Mitteilungen des Geologischen Institutes der ETH und der Universität Zürich, Neue Folge 275. 296 p.

Page, K.N., 1996. Mesozoic Ammonoids in Space and Time: In: Landman, N.H., Tanabe, K., Davis, R.A. (Eds.), Ammonoid paleobiology. Plenum, New York, London, pp. 755-794. Parkinson, J., 1811. The Fossil Starfish, Echini, Shells, Insects, Amphibia, Mammalia \& c. The Organic Remains of a Former World, vol. 3. Sherwood, Neely, and Jones, London, xvi + 479 p., 22 pls.

Parona, C.F., Bonarelli, G., 1897. Fossili Albiani d'Escragnolles, del Nizzardo e della Liguria occidentale. Palaeontologica Italiana 2 (1896), 53-112.

Pervinquière, L., 1910. Sur quelques ammonites du crètacè algèrien. Mémoires de la Société Géologique de France, Paléontologie 17, mémoir, 42, 1-86.

Pictet, F.J., 1847. Déscription des mollusques fossiles qui se trouvent dans les grès verts des environs de Genève. Mémoire de la Société de Physique et d'Histoires de Genève 11, 257412.

Pictet, F.J., 1854. Traité de Paléontologie. Tomé deuxiéme, 5e famille - Ammonitides. Second edition. J.-B. Bailliére, Paris, pp. 654-716, pl. 52-56. 
Pictet, F.J., Campiche, G., 1858-60. Description des fossiles du terrain Cretacé des environs de Sainte-Croix. I. Matériaux pour la Paléontologie Suisse, 2. série, 2, 29-368, Kessmann \& Georg, Geneva (no. 1: feuilles 1-3, carte geologique, pls. 1-2; April 1858, no. 2: feuilles 4-7, pls. 3-8; June 1858, no. 3: feuilles 8-12, pls. 9-13; October 1858, no. 4: feuilles 13-18, pls. 14-15; March 1859, no. 5: feuilles 19-22, pls. 18-23; August 1859, no. 6: feuilles 23-26, pls. 24-29; September 1859, no. 7: feuilles 27-32, pls. 30-34; January 1860, no. 8: feuilles 33-38, pls. 34-38; March 1860, no. 9: feuilles 39-48, pls. 39-43; May 1860).

Pictet, F.J., Campiche, G., 1858-64. Matériaux pour la paléontologie Suisse. Description des fossiles du terrain Crétacé des environs de Ste. Croix. Mat. pal. Suisse, 1, 1-380 (1858-60); 2, $1-752(1861-64)$.

Pictet, F.J., De Loriol, P., 1858. Description des fossils contenus dans le Terrain Néocomien des Voirons; seconde partie: description des animaux invertébrés. Matériaux pour la Paléontologie Suisse, Seconde Série (1858-60) 2,64 p., 12 pl.

Quenstedt, F.A., 1847. Petrefactenkunde Deutschlands. 1. Die Cephalopoden. 580 p. 36 pl. Tübingen.

Reboulet, S., Szives, O., Aguirre-Urreta, B., Barragán, R., Company, M., Idakieva, V., Tavera, J. M., 2014. Report on the 5th International Meeting of the IUGS Lower Cretaceous Ammonite Working Group, the Kilian Group (Ankara, Turkey, 31st August 2013). Cretaceous Research 50, 126-137.

Renz, O., 1982. The Cretaceous Ammonites of Venezuela. Birkhauser, Maravan, a subsidiary of Petroleos de Veneyuela, S.A. 132 p., 40 pls.

Ritterbush, K. A., Hoffmann, R., Lukeneder, A., De Baets, K., 2014. Pelagic palaeoecology: the importance of recent constraints on ammonoid palaeobiology and life history. Journal of Zoology 292, 229-241. 
Sala, P., Pfiffner, O.A., Frehner, M., 2014. The Alpstein in three dimensions: fold-and-thrust belt visualization in the Helvetic zone, eastern Switzerland. Swiss Journal of Geosciences 10, $177-195$.

Salfeld, H., 1924. Die Bedeutung der Konservativstämme für die Stammesentwicklung der Ammonoideen. Grundlinien für die Erforschung der Entwicklung der Ammonoideen der Juraund Kreidezeit. Verlag Max Weg, Leipzig, 16 p., 16 pls.

Sarkar, S., 1954. Some new genera of uncoiled ammonites from Lower Cretaceous. Science and Culture 19, 618-620.

Schenk, K., 1992. Die Drusberg- and Schrattenkalk-Formation (Unterkreide) im Helvetikum des Berner Oberlandes. Unpublished Ph.D. thesis, Geological Institute, University of Berne, 169 p. Scholz, G., 1979. Die Ammoniten des Vracon (Oberalb, Dispar-Zone) des Bakony-Gebirges (Westungarn) und eine Revision der wichtigsten Vracon-Arten der westmediterranen Faunenprovinz. Palaeontographica A 165(1-2), 1-136.

Seeley, H.G., 1865. On Ammonites from the Cambridge Greensand. Annals and Magazine of Natural History (3) 16, 225-247.

Seitz, O., 1931. Zur Morphologie der Ammoniten aus dem Albien II. Jahrbuch der Preußischen Geologischen Landesanstalt 52 (1931), 391-415.

Sepkoski, J. J., 1988. Alpha, beta, or gamma: where does all the diversity go? Paleobiology $14,221-234$.

Sharpe, D., 1857. Description of the fossil remains of Mollusca found in the Chalk of England. Part 3: Cephalopoda. Palaeontographical Society, London, pp. 37-70, pls. 17-27 (1856). Sowerby, J., 1812-1846. The mineral conchology of Great Britain. Vol.1-4, London, 1: pls. 1-9 (1812); pls. 10-44 (1813); pls. 45-78 (1814); pls. 79-102 (1815); 2: pls. 103-114 (1815); pls. 115-50 (1816); pls. 151-186 (1817); pls. 187-203 (1818); 3: pls. 204-221 (1818); pls. 222-253 (1819); pls. 254-271 (1820), pls. 272-306 (1821); 4: pls. 307-318 (1821); pls.319383 (1822); pls 384-407 (1823); 5: pls. 408-443 (1823), pls. 444-485 (1824); pls. 486-603 
(1825); 6: pls. 504-544 (1826); pls. 545-580 (1827); pls. 581-597 (1828); pls. 598-609 (1829); 7: pls. 610-618 (1840); pls. 619-623 (1841); pls. 624-628 (1843); pls. 629-643 (1844); pls. 644-648 (1846).

Spath, L.F., 1921. On Cretaceous Cephalopoda from Zululand. Annals of the South African Museum 12, 217-321.

Spath, L.F., 1922. On Cretaceous Ammonoidea from Angola, collected by Professor J.W.

Gregory, D. Sc., F.R.S. Transactions of the Royal Society of South Africa, 53, 91-160.

Spath, L.F., 1923-1943. A monograph of the ammonoidea of the Gault. Palaeontographical Society, London, (1923) I, pp. 1-72, pls. 1-4; (1925a) II, pp. 73-110, pls. 5-8 ; III, pp. 111146, pls. 9-12;(1926) IV, pp. 147-186, pls. 13-16; (1927) V, pp. 187-206. pls. 17-20; (1930), VII. pp. 265-311, pls. 25-30; (1931) VIII, pp. 313-378. pls. 30-36; (1932) IX, pp. 779-410, pls. 37-42; (1933) X. pp. 411-442, pls. 43-48; (1934) XI, pp. 443-496, pls. 49-56; (1937) XII, pp. 497-540, pls. 57, 58; (1939) XIII, pp. 541-608, pls. 59-64 ; (1941) XIV, pp. 609-668, pls. 65-72 ; (1942) XV, pp. 669-720 : (1943) XVI, pp. 721-787 et i-x.

Spath, L.F., 1925b. On Upper Albian Ammonoidea from Portuguese East Africa, with an appendix on Upper Cretaceous ammonites from Maputoland. Annals of the Transvaal Museum, 11, 179-200.

Steinmann, G., 1890. In: Steinmann, G., Döderlein L. (Eds.), Elemente der Paläontologie. Wilhelm Engelmann, Leipzig, 848 p.

Stoliczka, F., 1863-1866. The fossil Cephalopoda of the Cretaceous rocks of southern India. Ammonitidae with revision of the Nautilidae etc. Memoirs of the Geological Survey of India. (1), Palaeontologica Indica 3 (1), 41-56(1863); (2-5), 57-106(1864); (6-9), 107-154(1865); (10-13), 155-216(1866).

Suess, E., 1865. Über Ammoniten. Sitzungsberichte der Kaiserlichen Akademie der Wissenschaften in Wien, mathematisch-naturwissenschaftliche Klasse 52, Abteilung 1:71-89. 
Tajika, A., Morimoto, N., Wani, R., Naglik, C., Klug, C., 2015a. Intraspecific variation of phragmocone chamber volumes throughout ontogeny in the modern nautilid Nautilus and the Jurassic ammonite Normannites. PeerJ 3, e1306.

Tajika, A. Naglik, C. Morimoto, N. Pascual-Cebrian, E. Hennhöfer, D. Klug, C., 2015b.

Empirical 3D model of the conch of the Middle Jurassic ammonite microconch Normannites: its buoyancy, the physical effects of its mature modifications and speculations on their function. Historical Biology 27, 181-191.

Thieuloy, J.P., 1966. Leptocères berriasiens du massif de la Grande-Chartreuse. Travaux du Laboratoire Géologie de la Faculté des Sciences de Grenoble 42, 281-295.

Torcapel, A., 1884. Quelques fossils nouveaux de l'Urgonien du Languedoc. Bulletin de la Société d‘Étude des Sciences Naturelles de Nîmes 11,133-212.

Trautschold, H.A., 1886. Le Néocomien de Sably en Crimée. Nouveaux Mémoires de la Société impérial des Naturalistes de Moscou 15(4), 1- 25 p.

Trümpy, R., 1980, Geology of Switzerland, a guide-book: Schweizerische Geologische Kommission, Wepf \& Co., Basel, 334p.

Uhlig, V., 1882. Die Wernsdorfer Schichten und ihre Äquivalente. Sitzungberichte der Kaiserlichen Akademie der Wissenschaften in Iwen, Mathematisch-Naturwissenshaftliche Klasse 86(1), 86-117.

Uhlig, V., 1883. Die Cephaloopodenfauna der Werndorfer Schichten. Denkschriften der kaiserlichen Akademie der Wissenschaften, Wien, Mathematisch-Naturwissenschaftliche Classe 46, 127-290.

Vašíček, Z., Wiedmann J., 1994. The Leptoceratoidinae: small heteromorph ammonites from the Barremian. Palaeontology 37, 203-239.

Vermeulen, J. 1997. Kotetishvilia, nouveau genre barrémien de la sous-famille des Psilotissotiinae (Pulchelliidae, Endemocerataceae, Ammonoidea). Géologie Alpine 1996 72, $117-125$. 
Vermeulen, J., 2002. Etude stratigraphique et paléontologique de la famille des Pulchelliidae (Ammonoidea, Ammonitina, Endemocerataceae). Géologie alpine. Mémoire H.S, 42, Université Joseph-Fourier-Grenoble I, 333 p.

Vermeulen, J., Lazarin, P., Lepinay P., Leroy, L., Mascarelli, E., 2014. Ammonites du Barrémien du Sud-Est de la France (Ammonitina, Ancyloceratina, Turrilitina). Strata 50, 1-95. Wiedmann, J., 1960. Zur Systematik jungmesozoischer Nautiloidea. Palaeontographica A 115, 144-206.

Wiedmann, J., 1962. Ammoniten aus der Vascogotischen Kreide (Nordspanien) I. Phylloceratina, Lytoceratina. Palaeontographica A 118, 119-237.

Wiedmann, J., 1964. Unterkreide-Ammoniten von Mallorca. 2. Lieferung: Phylloceratina. Akademie der Wissenschaften und der Literatur. Abhandlungen der mathematischnaturwissenschaftliche Klasse 4(1963),151-264.

Wiedmann, J., 1965. Origin, limits, and systematic position of Scaphites. Palaeontology 8, $397-453$.

Wiedmann, J., 1966. Stammesgeschichte und System der posttriadischen Ammonoideen. Neues Jahrbuch für Geologie und Paläontologie, Abhandlungen 127, 13-81.

Wiedmann, J., Dieni, I., 1968. Die Kreide Sardiniens und ihre Cephalopoden. Palaeontographia Italica 64, 1-171.

Wiedmann, J., Schneider, H. L., 1979. Cephalopoden und Alter der Cenoman-Transgression von Mühlheim-Broich, SW-Westfalen. In: Wiedmann, Jost (Ed.) Aspekte der Kreide Europas, International Union of Geological Sciences, series A 6, 645-680, Stuttgart, Schweizerbart. Wright, C, W., 1952. A classificationo of the Cretaceous ammonites. Journal of Paleontology $26,213-222$.

Wohlwend, S., Hart, M., Weissert, H. 2015. Ocean current intensification during the Cretaceous oceanic anoxic event 2-evidence from the northern Tethys. Terra Nova 27, 147155. 
Wright, C., 1996. Treatise on Invertebrate Paleontology. Part L, Mollusca 4: Cretaceous Ammonoidea. xx+ 1-362 (with contributions by Calloman J.H., and Howarth, M.K.).

Lawrence, Kansas and Boulder. Geological Society of America and University of Kansas.

Wright, C.W., Kennedy, W.J., 1978. The ammonite Stoliczkaia from the Cenomanian of England and northern France. Palaeontology 21, 393-409.

Wright, C.W., Kennedy, W.J., 1984. The Ammonoidea of the Lower Chalk. Part 1.

Palaeontographical Society Monograph, 295-319.

Wright, C.W., Kennedy, W.J., 1994. Evolutionary relationships among Stoliczkaiinae

(Cretaceous ammonites) with an account of some species from the English Stoliczkaia dispar

Zone. Cretaceous Research 15, 547-582.

Wright, C.W., Kennedy, W.J., 1995. The Ammonoidea of the Lower Chalk. Part 4.

Palaeontographical Society Monograph, 1-126.

Wright, C.W., Kennedy, W.J., 1996. The Ammonoidea of the Lower Chalk. Part 5.

Palaeontographical Society Monograph, 320-403.

Wright, C.W., Kennedy, W.J., 2015. The Ammonoidea of the Lower Chalk. Part 6.

Palaeontographical Society Monograph, 404-460.

Zittel, K.A. v., 1881-1885. Handbuch der Palaeontologie 1. Abtheilung, Palaeozoologie. II. Band. Mollusca und Arthropoda. 893, 1109 p. München und Leipzig, Verlag R. Oldenbourg. Zittel, K.A. v., 1895. Grundzüge der Palaeontologie. 971 p. Oldenbourg, Münich and Leipzig. 


\section{Figure captions}

Fig. 1. Location \& geological map of the Alpstein. A. Location of the Alpstein. Simplified from Bodin et al. (2006). B, Localities in which fossils are collected (simplified from Eugster et al., 1982). 1, Altmann-Sattel, Südwest-Seite I. 2, Altmann-Sattel Nordost-Seite I. 3, Litten, Chreialp. 4, Wis (SW Alp Rohr). 5, Vorderalp, Frümsner Alp. 6, Chobel, Frümsner Berg. 7, Obertal (W Lütispitz). 8, Lochtem-Wagenlücke. 9, Chobel, Gartenalp. 10, Gartenwald, N Chobel. 11, Oberrieter Chienberg. 12, Säntis, Gasthaus-Galerie and surrounding. 13, Oberrieter Strüssler SE. 14, Schlatt (above Rüthi SG). 15, In Ränken, Plona. 16, Bergli, Sennwald. 17, Stofel, Lenziwis. 18, Wildhuser Schafboden gegen Pt. 2171. 19, Tal W II (NE Neuenalpspitz). 20, Chelen-Geren (SW Plona). 21, Unter-Hard, Rüthi SG. 22, Tierwis-Stütze 2 Säntisbahn I. 23, Stütze 2 Säntisbahn S. 24, Tierwis NE II. 25, Stütze 2 - Girenspitz/Säntis, Weg. 26, Hornwald (Hinter Gräppelen). 27, Tal-Wänneli (NE Neuenalpspitz). 28, NeuenalpKamm. 29, Zwinglipass Nordost. 30, Ebenalp, Übergang gegen Gartenalp. 31, Säntis, Gasthaus-Hang. 32, Hinterwinden (Hinter Gräppelen). 33, Hinterwinden-Hornwald (Hinter Gräppelen). 34, Hinderhorn (Hinter Gräppelen). 35, Mutteli. 36, Troosen. 37, Oberrieter Chienberg West. 38, Blauschnee-Girenspitz.

Fig. 2. Field images from the Alpstein near Tierwis. A, Tierwis area seen from Stütze 2. B, Tierwis Formation and Schrattenkalk Formation. C, Schrattenkalk Formation. D, Garschella Formation and Kamm Bed. E, cross sections of acanthoceratid ammonites at the base of the Seewen Formation. F, cross section of a big puzosiid ammonite at the base of the Seewen Formation.

Fig. 3. Stratigraphic sections of the Cretaceous at Tierwis of the Alpstein. Tierwis section 1, Tierwis Formation (Barremian)-Schrattenkalk Formation (Aptian). Tierwis section 2, Tierwis 
Formation (Barremian)-Seewen Formation (Cenomanian). Arrows indicate bedding planes or horizons in which palaeoecological study was carried out.

Fig. 4. Changes of ecospace use from the early Barremian (Altmann Member) to the early Cenomanian (Seewen Formation). Relative abundances of ecospace use are plotted. Size of the pie charts represents the sampling size.

Fig. 5. Nautilids from the Alpstein. A, B, M, N. Eucymatoceras plicatum (Fitton, 1835); A, B-NMSG (Coll. AT. 1), Lochtem-Wagenlücke; M, N-ETHZ 10434, Kohlbett below the Seealpsees. C, D, K, L, Eutrephoceras sublaevigatum (d'Orbigny, 1850); C, D- NMSG (Coll. KT. HW-A-0039-1), Hinterwinden-Hornwald (Hinter Gräppelen). K, L-NMSG (Coll. PK. 7.B.25.33), Bergli, Sennwald. E, F, Cymatoceras neocomiense (d'Orbigny), 1840; NMSG (Coll. PK. 7.B.06.01), Oberrieter Chienberg. G, H, Cymatoceras subradiatum (d'Orbigny, 1850); ETHZ 10435, Toggenburg. I, J, Eutrephoceras perlatum (Morton, 1834); NMSG (Coll. PK. 7.C.18.01), Mutteli.

Fig. 6. Nautilids and ammonoids from the Alpstein. A-D, Eutrephoceras montmollini (Pictet and Campiche), 1859; A, B-NMSG (Coll. PK. 7.C.02.11); C, D-NMSG (Coll. PK.

7.C.02.19), Stütze 2 Säntisbahn S. E, F, I-L, O, P, V, W, Barremites cf. difficilis (d'Orbigny, 1841); E, F-NMSG (Coll. PK. 5.A.05.74); I, J-NMSG (Coll. PK. 5.A.05.25); K, L-NMSG (Coll. PK. 5.A.05.75), Altmann-Sattel, Südwest-Seite I; O, P-NMSG (Coll. PK. 5.A.06.01), Altmann-Sattel Nordost-Seite; V, W-NMSG (Coll. UO. 001), Spitzbergli. G, H, Eutrephoceras perlatum (Morton, 1834); NMSG (Coll. PK. 7.B.09.02) Säntis, GasthausGalerie and surrounding. M, N, Torcapella cf. fabrei (Torcapel, 1884); NMSG (Coll. PK. 5.A.05.30), Altmann-Sattel, Südwest-Seite I. Q, Torcapella sp.; NMSG (Coll. PK. 5.A.05.29), Altmann-Sattel, Südwest-Seite I. R, S, Kotetishvilia compressissima (d'Orbigny, 1841); NMSG (Coll. PK. 5.A.05.26), Altmann-Sattel, Südwest-Seite I. T, U, Nicklesia pulchella (d'Orbigny, 1841); NMSG (Coll. KT. AS-W-0026), Altmann-Sattel, Südwest-Seite I. X, Y, 
Torcapella falcata Busnardo, 1970; NMSG (Coll. PK. 5.A.05.87), Altmann-Sattel, SüdwestSeite I. Z-AC, Puzosia (Puzosia) quenstedti quenstedti (Parona and Bonarelli, 1897); Z, AANMSG (Coll. PK. 7.B.23.34), In Ränken, Plona; AB, AC- NMSG (Coll. PK. 7.C.02.38), Stütze 2 Säntisbahn S. AD, AE, Puzosia (Puzosia) provincialis (Parona and Bonarelli, 1897); NMSG (Coll. PK. 7.B.20.73), Schlatt (above Rüthi SG). AF, AG, Puzosia (Puzosia) lata Seitz, 1931; NMSG (Coll. PK. 7.B.20.74), Schlatt (above Rüthi SG). AH, AI, Desmoceras (Desmoceras) latidorsatum (Michelin, 1838); NMSG (Coll. PK. 7.B.32.04), Wildhuser Schafboden gegen Pt. 2171. AJ, AK, Puzosia (Puzosia) mayoriana (d'Orbigny, 1841); NMSG (Coll. PK. 7.B.23.05), In Ränken, Plona.

Fig. 7. Ammonoids from the Alpstein. A, B, Torcapella davydovi (Trautschold, 1886); NMSG (Coll. PK. 5.A.17.01), Chobel, Frümsner Berg. C, D, Puzosiinae indet.; ETHZ 10437, locality, unknown. E-H, L-O, Puzosia (Puzosia) mayoriana (d'Orbigny, 1841); E, F- NMSG (Coll. PK. 7.C.13.12), Säntis, Gasthaus-Hang; G, H- NMSG (Coll. PK. 7.B.23.13), In Ränken, Plona; L, M-NMSG (Coll. PK. 7.C.07.04), Tal-Wänneli (NE Neuenalpspitz); N, O- NMSG (Coll. PK. 7.C.13.40), Säntis, Gasthaus-Hang. I, X-AA, AL, AM, Beudanticeras cf. beudanti (Brongniart, 1822); I- NMSG (Coll. PK. 7.B.17.01), Oberrieter Strüssler SE; X, Y-NMSG (Coll. PK. 7.B.20.14); Z, AA-NMSG (Coll. PK. 7.B.20.41), Schlatt (above Rüthi SG), AL, AM-NMSG (Coll. PK. 7.B.25.10), Bergli, Sennwald. J, K, Puzosia (Puzosia) lata Seitz 1931; NMSG (Coll. PK. 7.C.15.13), Hinterwinden-Hornwald (Hinter Gräppelen). P-S, AD, Hysteroceras orbignyi Spath, 1922; P, Q- NMSG (Coll. PK. 7.B.25.02), AD- NMSG (Coll. PK. 7.B.25.35) Bergli, Sennwald; R, S, NMSG (Coll. PK. 7.B.26.06), Stofel, Lenziwis. T, U, Hysteroceras crassicostatum (Jayet, 1929); NMSG (Coll. PK. 7.B.26.16), Stofel, Lenziwis. V, W, Puzosia (Puzosia) cf. provincialis (Parona and Bonarelli, 1897); NMSG (Coll. PK. 7.B.26.01), Stofel, Lenziwis. AB, AC, Hysteroceras binum (Sowerby, 1815); NMSG (Coll. PK. 7.B.20.36), Schlatt (above Rüthi). AE-AI, Cantabrigites sp.; AE, AF- NMSG (Coll. PK. 
7.C.15.31), AH, AI- NMSG (Coll. PK. 7.C.15.21), Hinterwinden-Hornwald (Hinter

Gräppelen); AG-NMSG (Coll. PK. 7.B.35.01), Tal W II (NE Neuenalpspitz). AJ, AK, Hysteroceras varicosum (Sowerby, 1824); NMSG (Coll. PK. 7.B.23.21), In Ränken, Plona.

Fig. 8. Ammonoids from the Alpstein. A, B, Mortoniceras perinflatum (Sowerby, 1817); NMSG (Coll. KT. HW-A-0030), Hinterwinden-Hornwald (Hinter Gräppelen). C, D, Mortoniceras sp.; NMSG (Coll. PK. 7.B.20.20), Schlatt (above Rüthi SG). E-J, Mortoniceras inflatum (Sowerby, 1818); E, F- NMSG (Coll. PK. 7.B.20.44); I, J- NMSG (Coll. KT. Rü-S0021), Schlatt (above Rüthi SG). G, H, Mortoniceras rostratum (Sowerby 1817); NMSG (Coll. PK. 7.B.20.57), Schlatt (above Rüthi SG). K, L, Dipoloceras cf. pseudaon Spath, 1931; NMSG (Coll. PK. 7.B.20.23), Schlatt (above Rüthi SG). M, N, Stoliczkaiella (Stoliczkaiella) notha (Seeley, 1865); NMSG (Coll. PK. 7.C.12.03), Ebenalp, Übergang gegen Gartenalp. O, P, Stoliczkaiella (Stoliczkaiella) clavigera (Neumayr, 1875); NMSG (Coll. PK. 7.C.12.04), Ebenalp, Übergang gegen Gartenalp. Q, R, W, X, AE, AF, Mantelliceras saxbii (Sharpe, 1857); Q, R-STG_4, locality unknown; W, X-NMSG (Coll. KT. TW-G-0001), Stütze 2 Säntisbahn S; AE, AF-NMSG (Coll. UO. 003), Säntis. S, T, Stoliczkaiella (Lamnayella) crotaloides (Stoliczka, 1864); NMSG (Coll. PK. 7.C.12.01), Ebenalp, Übergang gegen Gartenalp. U, V, Desmoceras (Desmoceras) latidorsatum (Michelin, 1838); NMSG (Coll. PK. 7.C.15.15), Hinterwinden-Hornwald (Hinter Gräppelen). Y, Z, AA, AB, Holcodiscus sp.; Y, Z-NMSG (Coll. PK. 5.A.16.01), Vorderalp, Frümsner Alp; AA, AB-NMSG (Coll. PK. 5.A.05.42), Altmann-Sattel, Südwest-Seite I. AC, AD, Astieridiscus morleti (Kilian, 1889); NMSG (Coll. PK. 5.A.13.06), Wis (SW Alp Rohr).

Fig. 9. Ammonoids from the Alpstein. A, B, Mantelliceras saxbii (Sharpe, 1857); A, BNMSG (Coll. PK. 7.C.13.28), Säntis, Gasthaus-Hang. C, D, Stoliczkaiella (Stoliczkaiella) clavigera (Neumayr, 1875); NMSG (Coll. PK. 7.C.12.05), Ebenalp, Übergang gegen Gartenalp. E, F, Desmoceras (Desmoceras) latidorsatum (Michelin, 1838); NMSG (Coll. PK. 
7.B.37.10), Chelen-Geren (SW Plona). G, H, Douvilleiceras sp.; NMSG (Coll. PK. 7.B.42.14), Bergli Nord, Sennwald. I-L, Stoliczkaiella (Lamnayella) juigneti Wright and Kennedy, 1978; I, J-NMSG (Coll. PK. 7.C.05.04), Hornwald (Hinter Gräppelen); K, L-NMSG (Coll. PK. 7.C.11.09), Säntis, Gasthaus-Galerie and surrounding. M, N, U, V, Holcodiscus caillaudianus (d’Orbigny, 1850); M, N-NMSG (Coll. PK. 5.A.05.27); U, V- NMSG (Coll. PK. 5.A.05.85), Altmann-Sattel, Südwest-Seite I. W, X-Parasaynoceras tzankovi (Avram, 1995); NMSG (Coll. PK. 5.A.05.86), Altmann-Sattel, Südwest-Seite I. O, P, Forbesiceras largilliertianum (d'Orbigny, 1841); NMSG (Coll. PK. 7.C.13.35), Säntis, Gasthaus-Hang. Q, R, Callihoplites tetragonus (Seeley, 1865); NMSG (Coll. UO. 017), Säntis. S, T, AF, Lechites gaudini (Pictet and Campiche, 1861); S- NMSG (Coll. PK. 7.C.14.03), Hinterwinden (Hinter Gräppelen); TNMSG (Coll. PK. 7.B.20.06), Schlatt (above Rüthi SG); AF-NMSG (Coll. PK. 7.C.13.42), Lochtem-Grüenböhl. Y, Z, Hamulinites sp.; NMSG (Coll. KT. ASW_0048), Altmann-Sattel, Südwest-Seite I. AA, AB, AE, Leptoceratoides cf. heeri Ooster, 1860; AA, AB- NMSG (Coll. PK. 5.A.05.24); AE-NMSG (Coll. KT. AS-W-0043), Altmann-Sattel Südwest-Seite. I. AC, AD, Hyphoplites curvatus curvatus Mantell, 1822; NMSG (Coll. TB. STWG_CE34), Blauschnee-Girenspitz. AJ, Sciponoceras roto Cieśliński, 1959; NMSG (Coll. UO. 008), Säntis. AG, Sciponoceras baculoides (Mantell, 1822); NMSG (Coll. PK. 7.C.13.06), Säntis, Gasthaus-Hang. AH, Bochianitinae indet.; NMSG (Coll. KT. ASW_0045) Altmann-Sattel, Südwest-Seite I. AI, Anisoceras armatum (Sowerby, 1817); NMSG (Coll. KT. NA-K-0001), Neuenalp-Kamm, Kamm Bed. AK, AL, Schloenbachia varians (Sowerby, 1817); NMSG (Coll. UO. 018), Säntis.

Fig. 10. Ammonoids from the Alpstein. A. Pseudothurmannia sp.; ETHZ 10436, Weesen. B, E, Emericiceras sp.; B-NMSG (Coll. PK. 5.A.02.15), Tierwis NE II; E- NMSG F 13599, Seealp. C, D, Crioceratitinae ind.; ETHZ 10438, Altmann. F, K, L, Anisoceras armatum (Sowerby, 1817); NMSG (Coll. PK. 7.C.07.05), Tal-Wänneli (NE Neuenalpspitz); K- NMSG 
(Coll. PK. 7.B.25.23), Bergli, Sennwald; L, NMSG (Coll. PK. 7.B.23.15), In Ränken, Plona. G, Anisoceras perarmatum Pictet and Campiche, 1861; NMSG (Coll. PK. 7.C.06.03), Tal W (NE Neuenalpspitz). H, Hamites cf. maximus Sowerby, 1814; NMSG (Coll. KT. HW-A0013), Hinterwinden-Hornwald (Hinter Gräppelen). I, J, Anisoceras pseudoelegans (Pictet and Campiche, 1861); I, J- NMSG (Coll. PK. 7.C.15.11), Hinterwinden-Hornwald (Hinter Gräppelen). M, Prohelicoceras moutonianum (d’Orbigny, 1850); NMSG (Coll. PK.

7.B.26.04), Stofel, Lenziwis. N, Hamites simplex d'Orbigny, 1842; NMSG (Coll. PK. 7.C.13.05), Säntis, Gasthaus-Hang. O, Hamites cf. similis Casey, 1961; NMSG (Coll. PK. 7.B.23.28), In Ränken, Plona. P, Hamites subvirgulatus Spath, 1941; NMSG (Coll. PK. 7.C.02.07), Stütze 2 Säntisbahn S. Q, Hamites sp.; NMSG (Coll. KT. CH-O-0001), Oberrieter Chienberg. R, Hamites compressus Sowerby, 1814; NMSG (Coll. PK. 7.C.11.01), Säntis, Gasthaus-Galerie and surrounding. S, Hamites virgulatus Brongniart, 1822; NMSG (Coll. PK. 7.B.26.13), Stofel, Lenziwis. T, Hamites duplicatus Pictet and Campiche, 1861; NMSG (Coll. PK. 7.C.19.04), Lochtem-Grüenböhl.

Fig. 11. Ammonoids from the Alpstein. A, B, Idiohamites cf. dorsetensis Spath, 1926; NMSG (Coll. PK. 7.C.02.23), Stütze 2 Säntisbahn S. C, Hypoturrilites cf. collignoni Wright and Kennedy, 1996; NMSG (Coll. PK. 7.C.01.14), Tierwis-Stütze 2 Säntisbahn I. D, I, K, Mariella bergeri (Brongniart, 1822); D- NMSG (Coll. PK. 7.C.13.01), Säntis, Gasthaus-Hang. I- NMSG (Coll. UO. 010), Säntis; K-NMSG (Coll. PK. 7.C.08.06), Neuenalp-Kamm. E, Hypoturrilites gravesianus (d'Orbigny, 1842); NMSG (Coll. PK. 7.C.15.19), HinterwindenHornwald (Hinter Gräppelen). F, Hypoturrilites cf. sharpei Wright and Kennedy, 1996; NMSG (Coll. PK. 7.C.15.34), Hinterwinden-Hornwald (Hinter Gräppelen). G, Ostlingoceras costulatum (Pervinquiére, 1910); NMSG (Coll. PK. 7.C.06.02), Tal W (NE Neuenalpspitz). H, R, Ostlingoceras puzosianum (d'Orbigny, 1842); H- NMSG (Coll. UO. 015), Säntis; RNMSG (Coll. Kürsteiner 7.C.15.32), Hinterwinden-Hornwald. J, O, S-U, Mariella miliaris 
(Pictet and Campiche, 1861); J-NMSG (Coll. PK. 7.C.19.09), Lochtem-Grüenböhl; ONMSG (Coll. UO. 014), Säntis; S- NMSG (Coll. PK. 7.C.19.10), Lochtem-Grüenböhl; TNMSG (Coll. PK. 7.C.15.33), Hinterwinden-Hornwald; U- NMSG (Coll. UO. 013); Säntis. L, Mariella gresslyi (Pictet and Campiche, 1861); NMSG (Coll. PK. 7.B.37.20), Chelen-Geren (SW Plona). M, Turrilitoides intermedius (Pictet and Campiche, 1861); NMSG (Coll. KT. SG-AG-0002) Säntis, Gasthaus-Hang. N, Scaphites hugardianus d'Orbigny 1842; NMSG (Coll. UO. 016), Säntis. P, Neostlingoceras carcitanense (Matheron, 1842); ETHZ_10424, Gartenalp. Q, Eoscaphites subcircularis (Spath, 1937); NMSG (Coll. PK. 7.B.26.02), Stofel, Lenziwis. V, W, Tetragonites jurinianus jurinianus (Pictet, 1847); NMSG (Coll. PK. 7.C.11.03), Säntis, Gasthaus-Galerie and surrounding. X, Y, Scaphites $\mathrm{cf}$. simplex (JukesBrowne), 1875; NMSG (Coll. KT. Sä-GS-0020), Säntis, Gasthaus Hang, Wannenalp-Schicht. Z, AA, Phylloceras (Hypophylloceras) velledae velledae (Michelin, 1834); NMSG (Coll. PK. 7.C.02.04), Stütze 2 Säntisbahn S. AB, AC, Kossmatella muhlenbecki (Fallot, 1885); NMSG (Coll. PK. 7.B.37.31), Chelen-Geren (SW Plona). AD, AE, Pseudothurmannia mortilleti (De Loriol and Pictet, 1858); STG_11, locality unknown. AF, AG, Gorethophylloceras subalpinum (d'Orbigny, 1841); NMSG (Coll. PK. 7.B.20.21), Schlatt (above Rüthi SG). AH, AI, Kossmatella agassiziana (Pictet, 1847); NMSG (Coll. PK. 7.C.14.02), Hinterwinden. AJ, AK, Tetragonites timotheanus timotheanus (Pictet, 1847); NMSG (Coll. PK. 7.B.23.03), In Ränken, Plona.

Fig. 12. Changes of tiering from the Early Barremian from the Barremian (Altmann Member) to the Early Cenomanian (Seewen Formation). Relative abundances are plotted.

Fig. 13. Correlation between sea level changes and palaeoecology. Ammonite zones are from Reboulet et al. (2014), Wright and Kenndy (1984) and Gale et al. (2011).

Fig. 14. Palaeoecological reconstruction of the early late Barremian. (A) Habitat of the early late Barremian. (B) Representatives of the early late Barremian macroorganism association. 
Fig. 15. Palaeoecological reconstruction of the late Albian. (A) Habitat of the late Albian. (B) Representatives of the late Albian macroorganism association.

Table 1. Ecologic categories for tiering, motility level and feeding mechanism (modified from Bush et al. 2007).

Table 2. Fossil abundances from the early Barremian (Altmann Member) to the early Cenomanian (base of the Seewen Formation). 


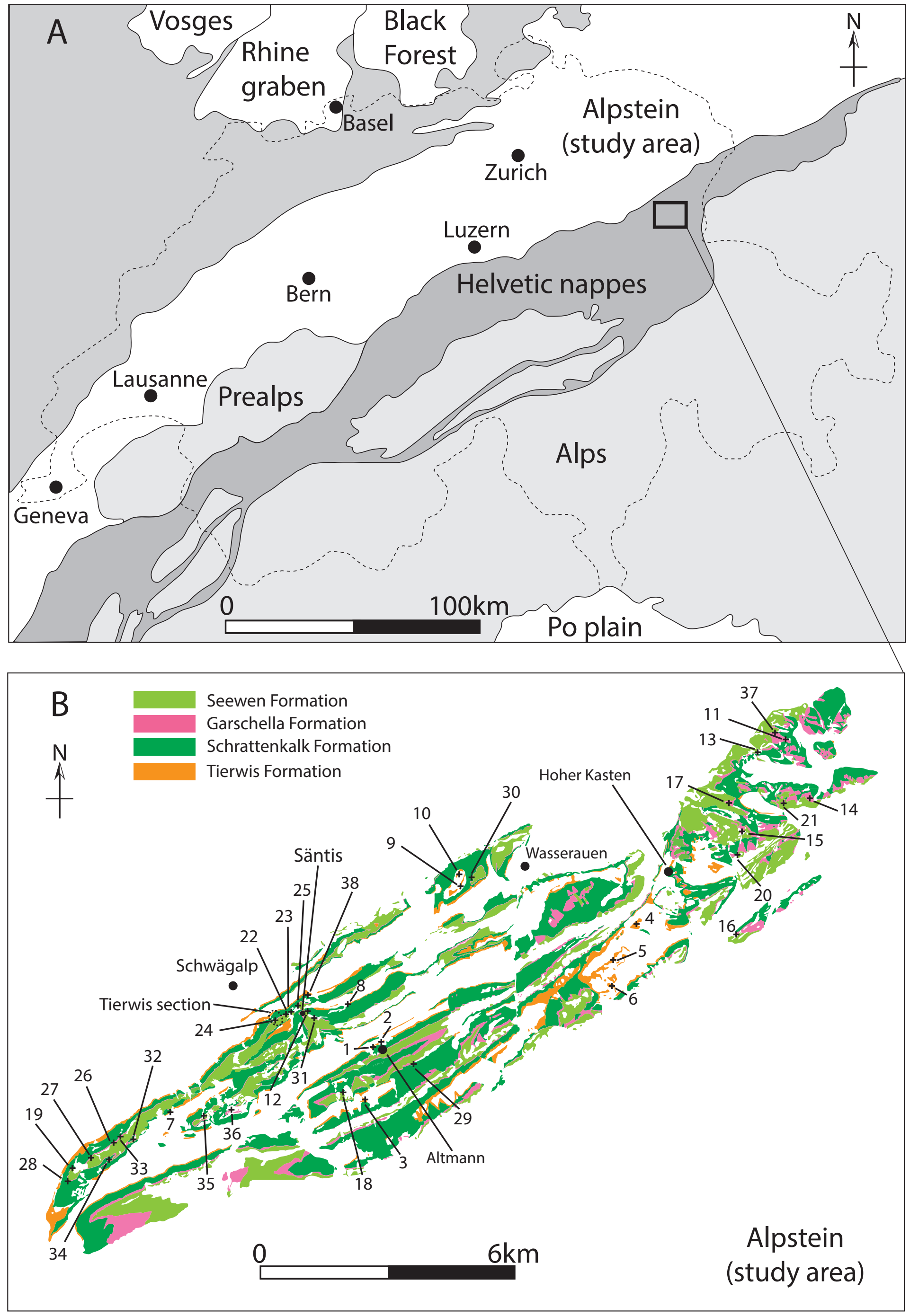




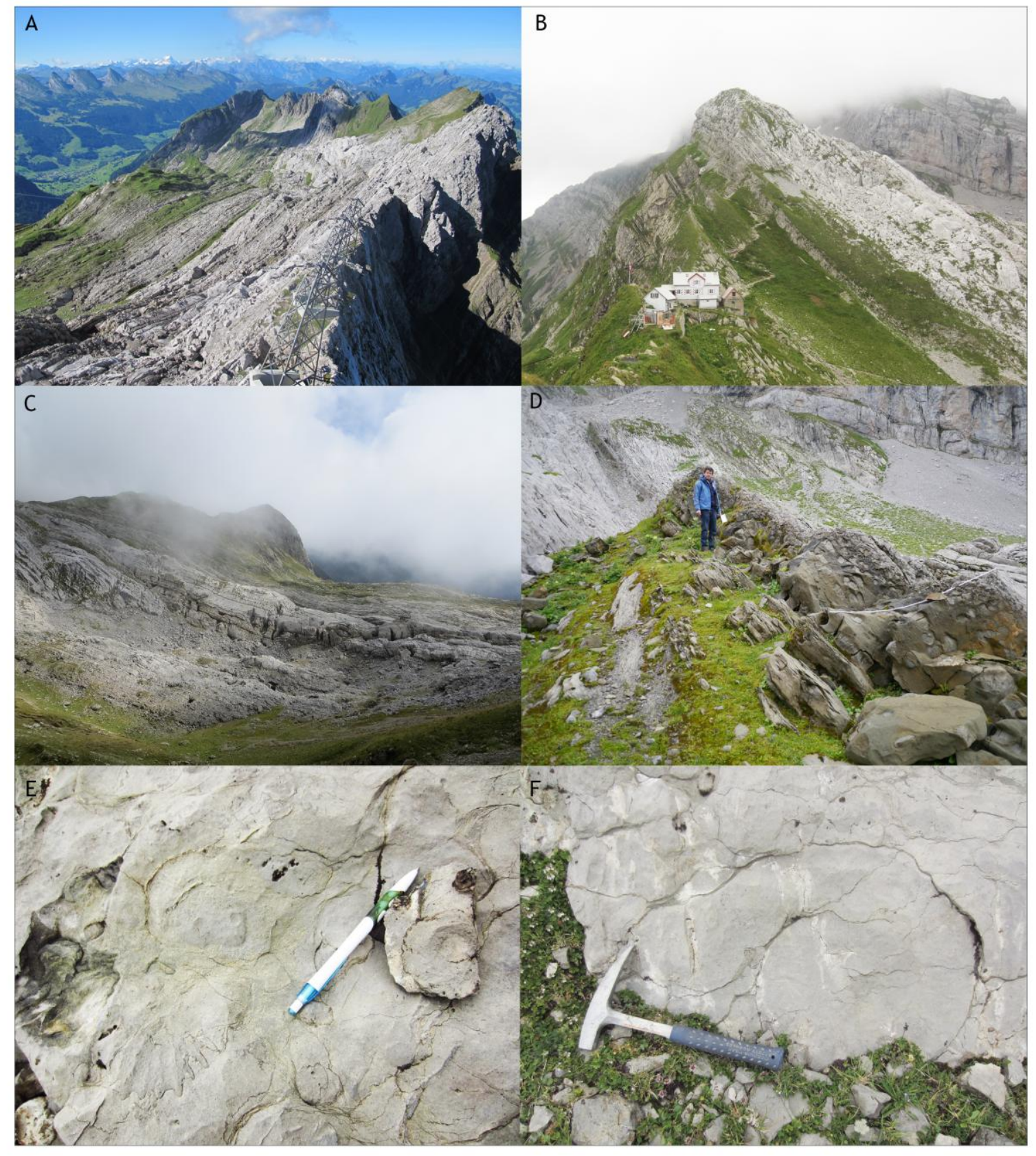




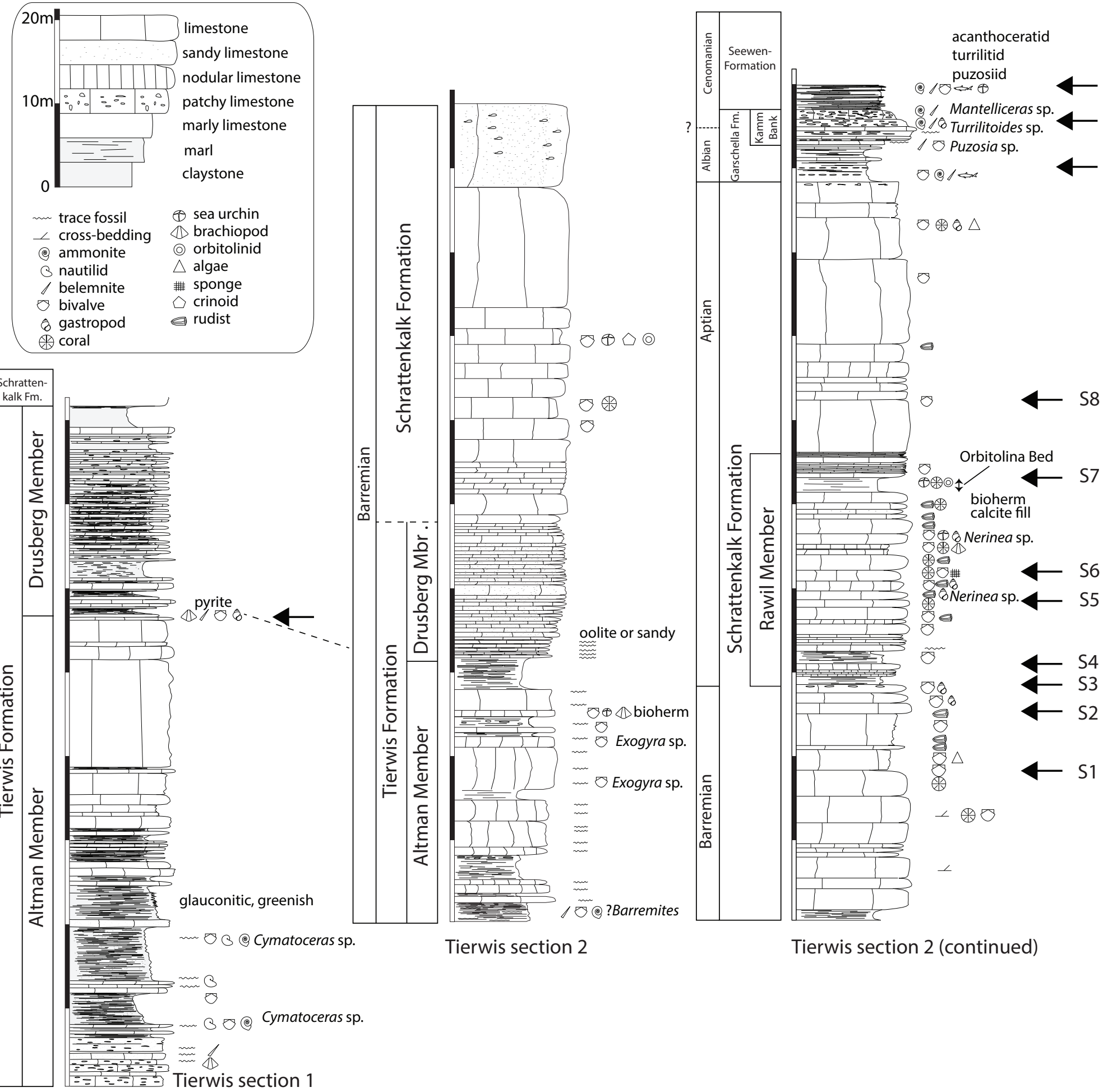




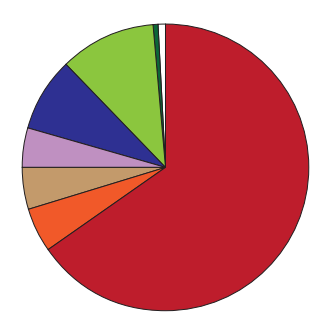

early Barremian (Altmann-Member)

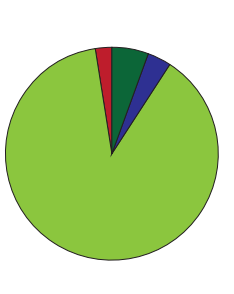

S1

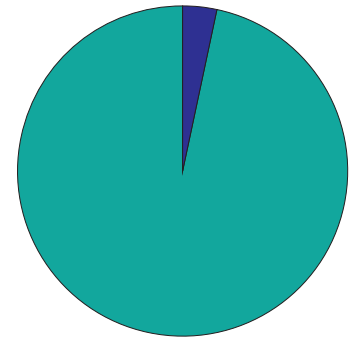

S2

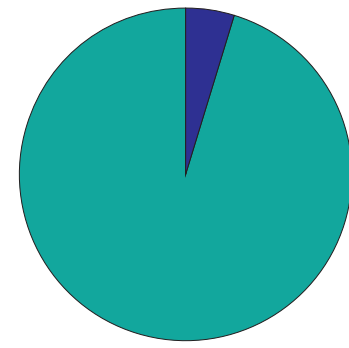

S3

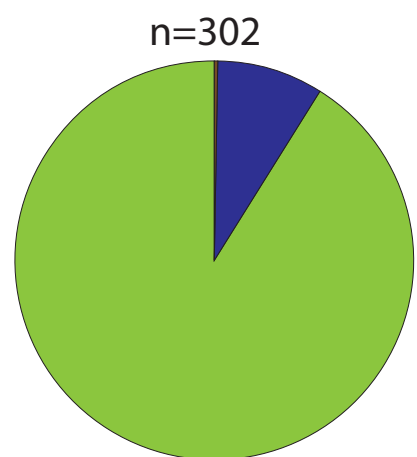

S4

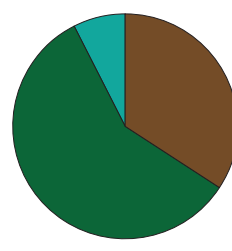

S5

late Barremian-Aptian (Schrattenkalk-Formation)

$\mathrm{n}=91$

$$
n=45
$$

$\mathrm{n}=80$

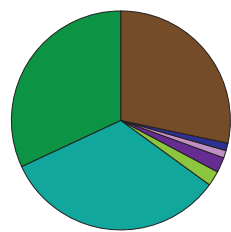

S6

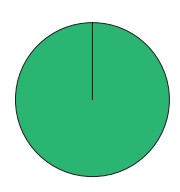

S7

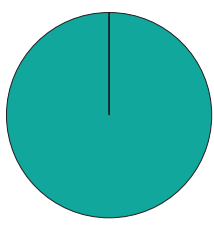

S8

Aptian (Schrattenkalk-Formation)

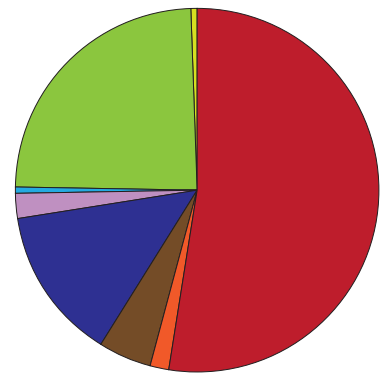

late Albian

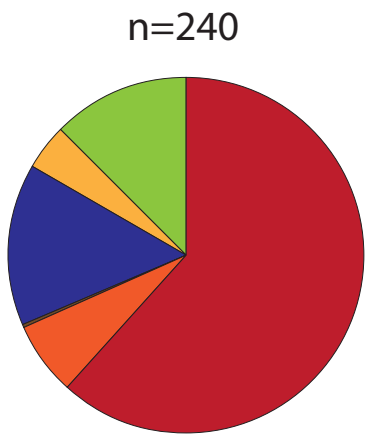

latest Albianearly Cenomanian (Kamm-Bank)
Pelagic; freely-fast; predators

Pelagic; freely-slow; predators

Erect; facultative, attached; suspension

Erect; non-motile, attached; suspension

Erect; non-motile, attached; other

Surficial; non-motile, attached; suspension

Surficial; freely-slow; grazing

Surficial; freely-slow; indet.
Surficial; non-motile, unattached; suspension Shallow-infaunal; non-motile, attached; suspension Semi-infaunal; non-motile, unattached; suspension Semi-infaunal; non-motile, attached; suspension Infaunal (deep-, shallow- or semi-); facultative-attached or unattached; suspension, surface deposit or mining

Infaunal (deep-, shallow- or semi- ); facultative, unattached; surface deposit Indeterminable 


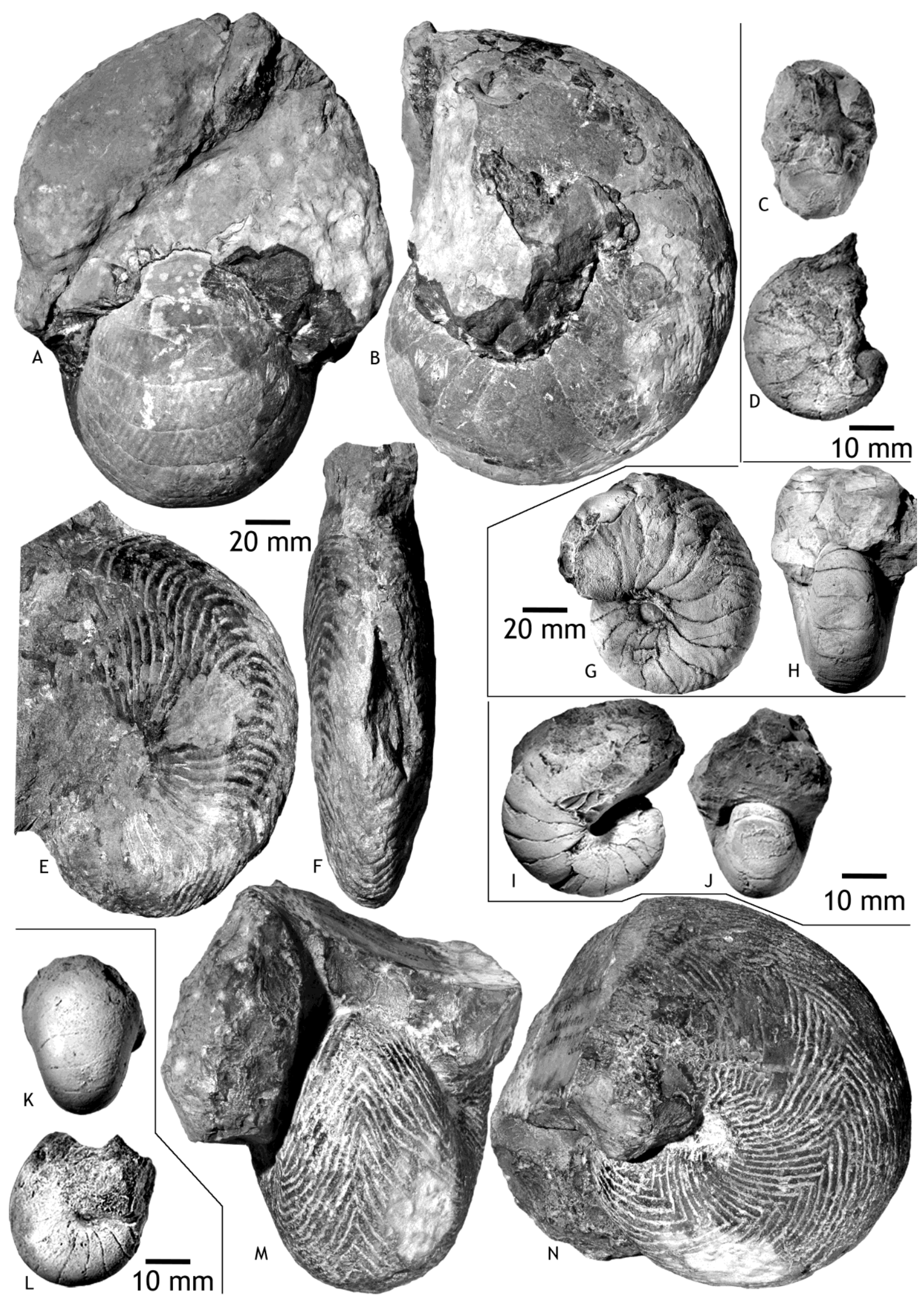




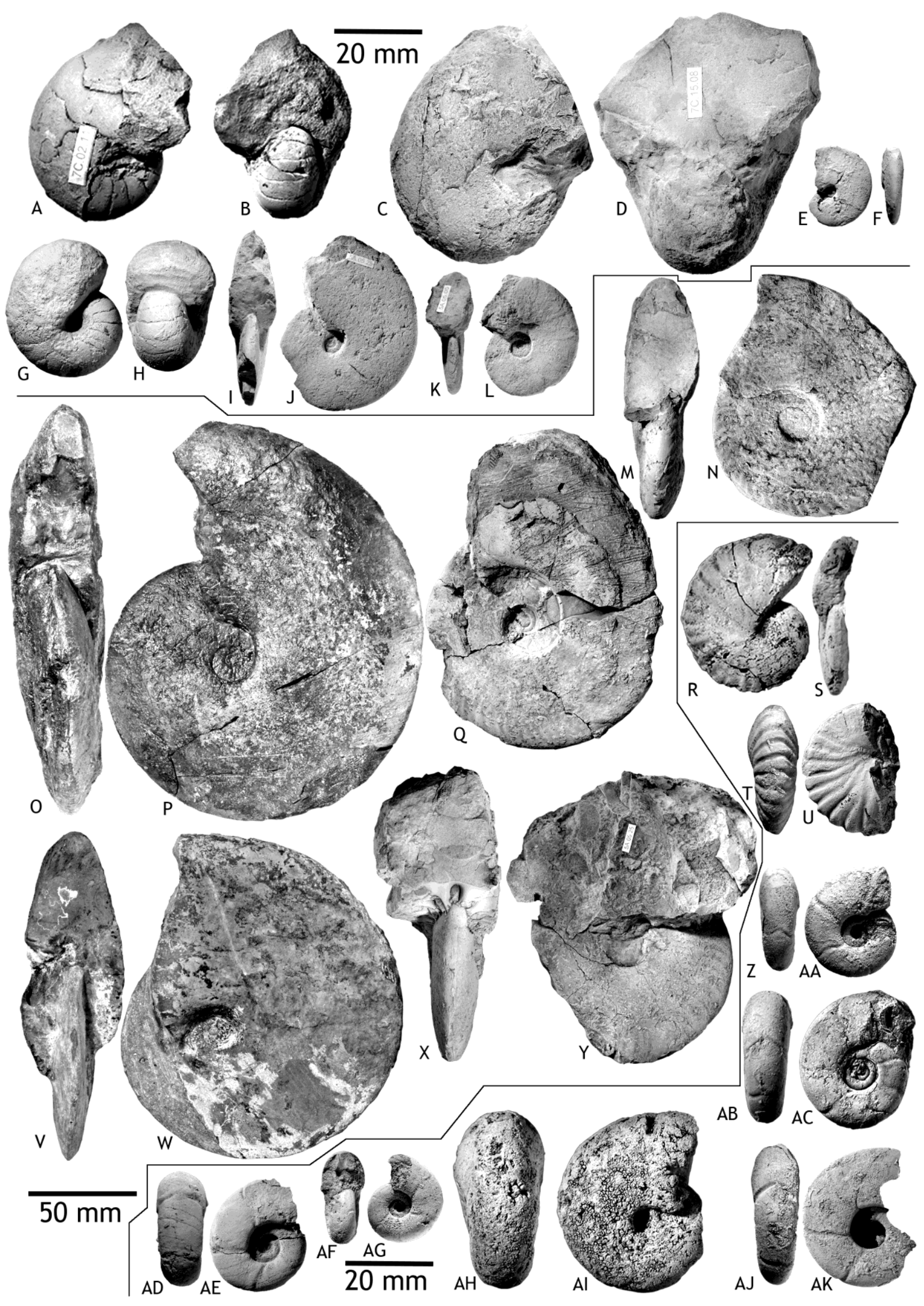




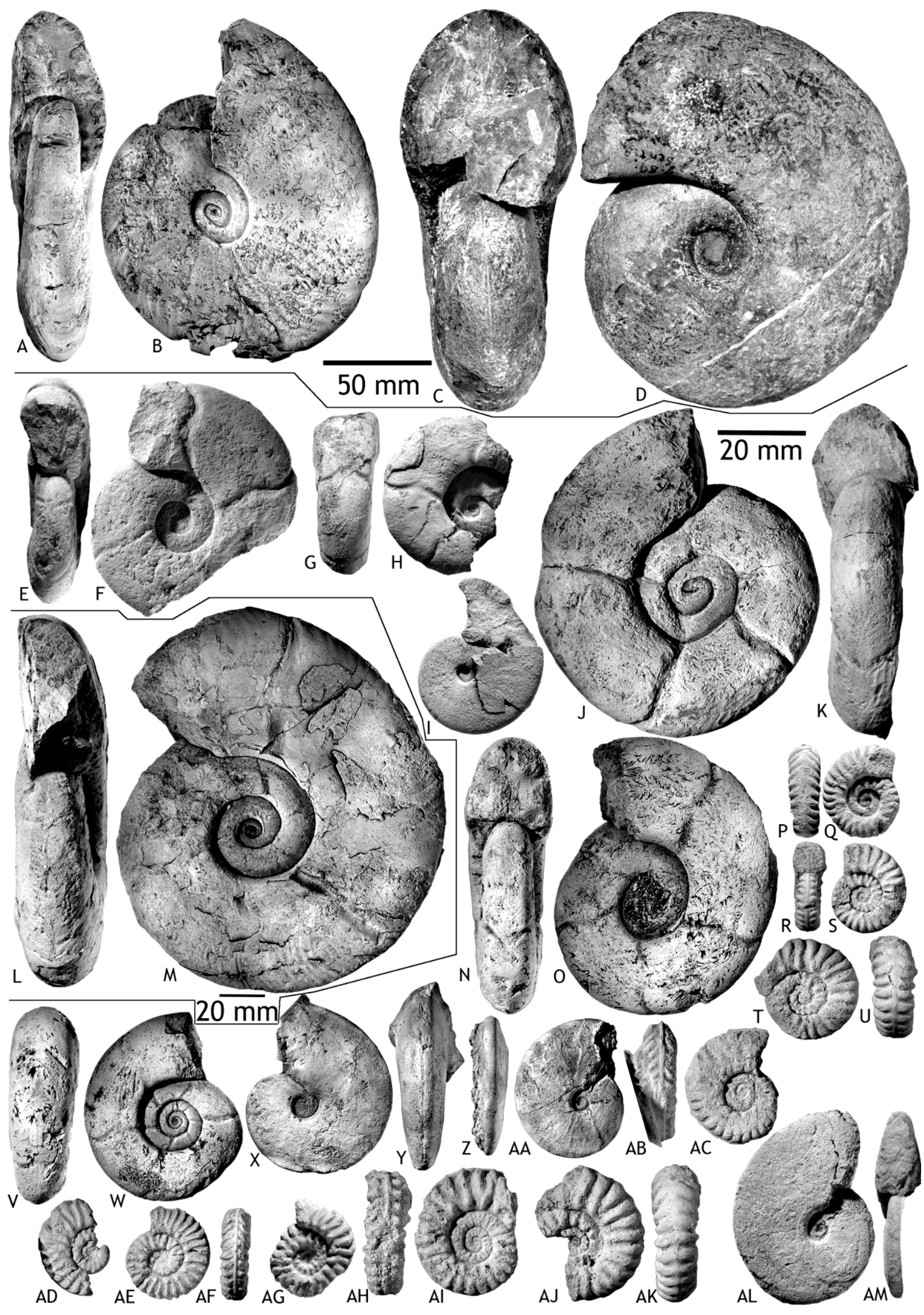




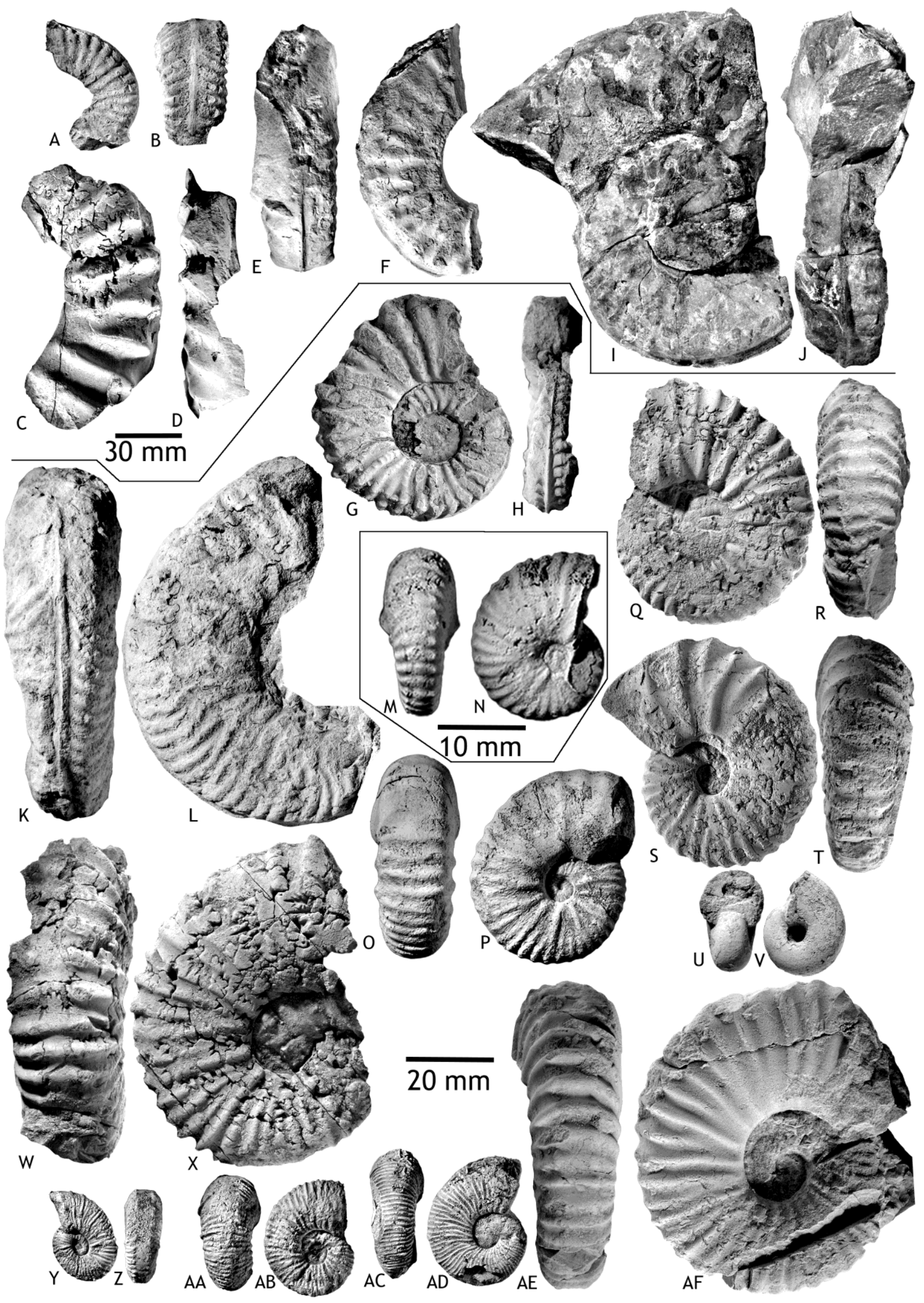




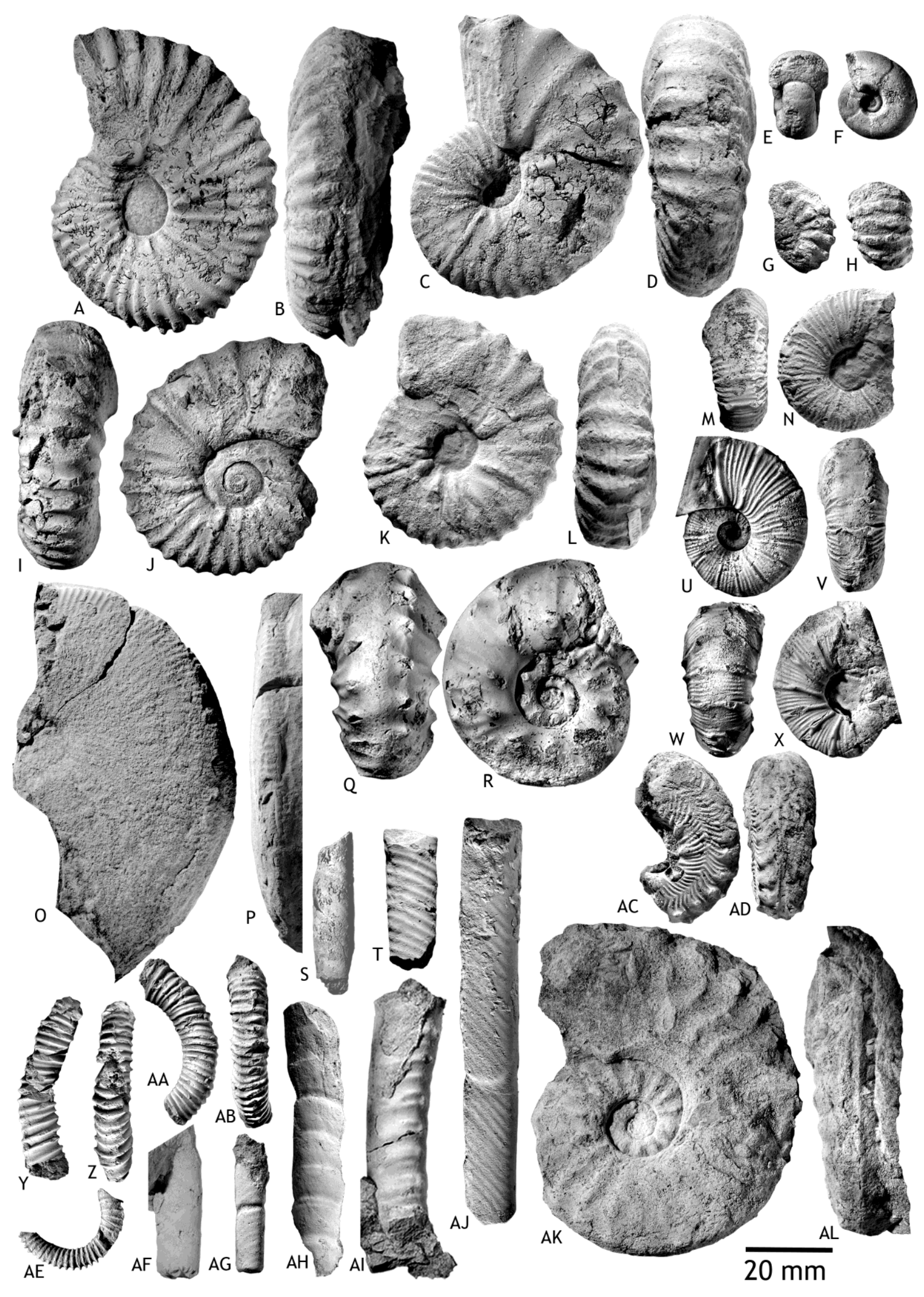




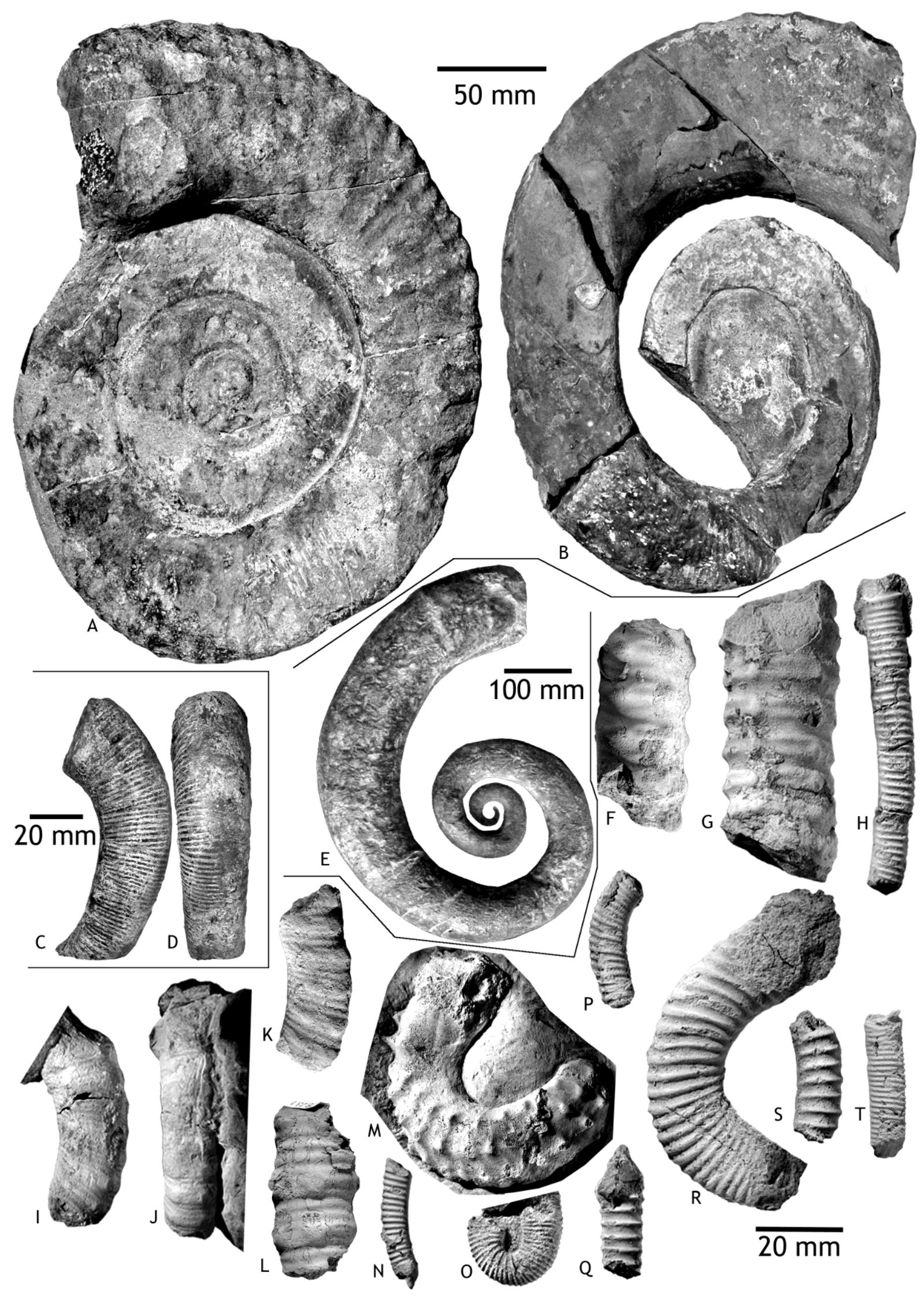




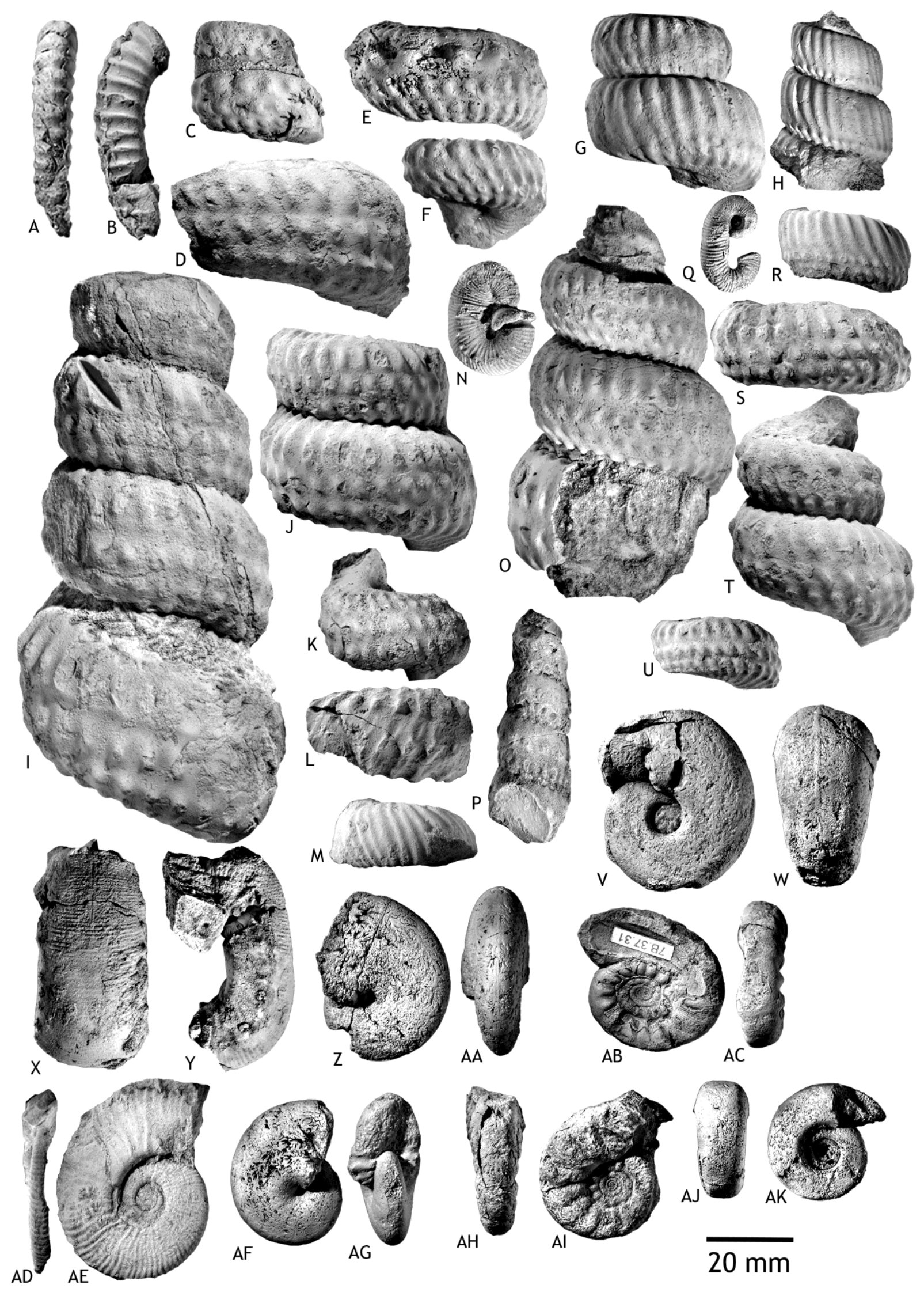




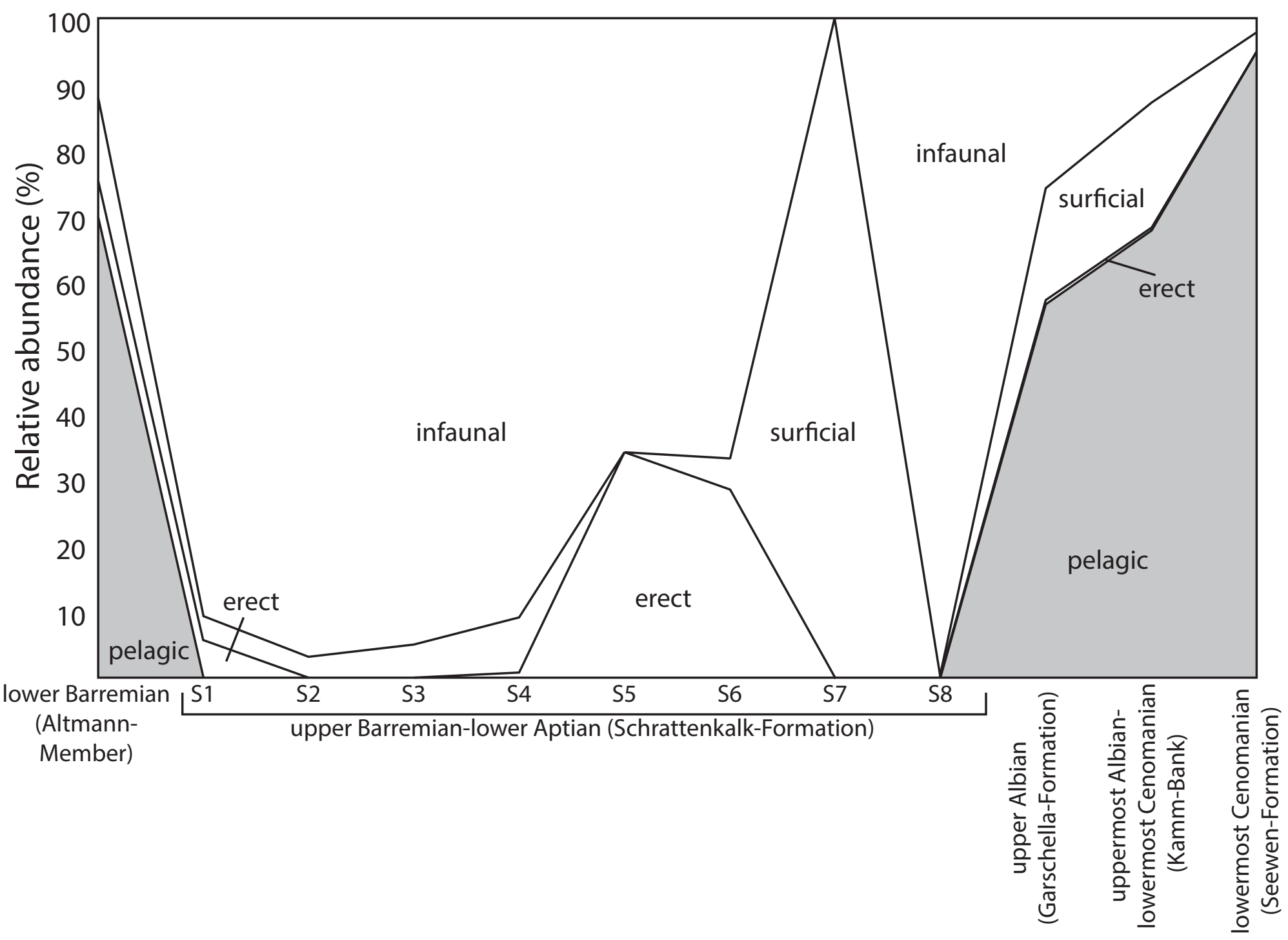




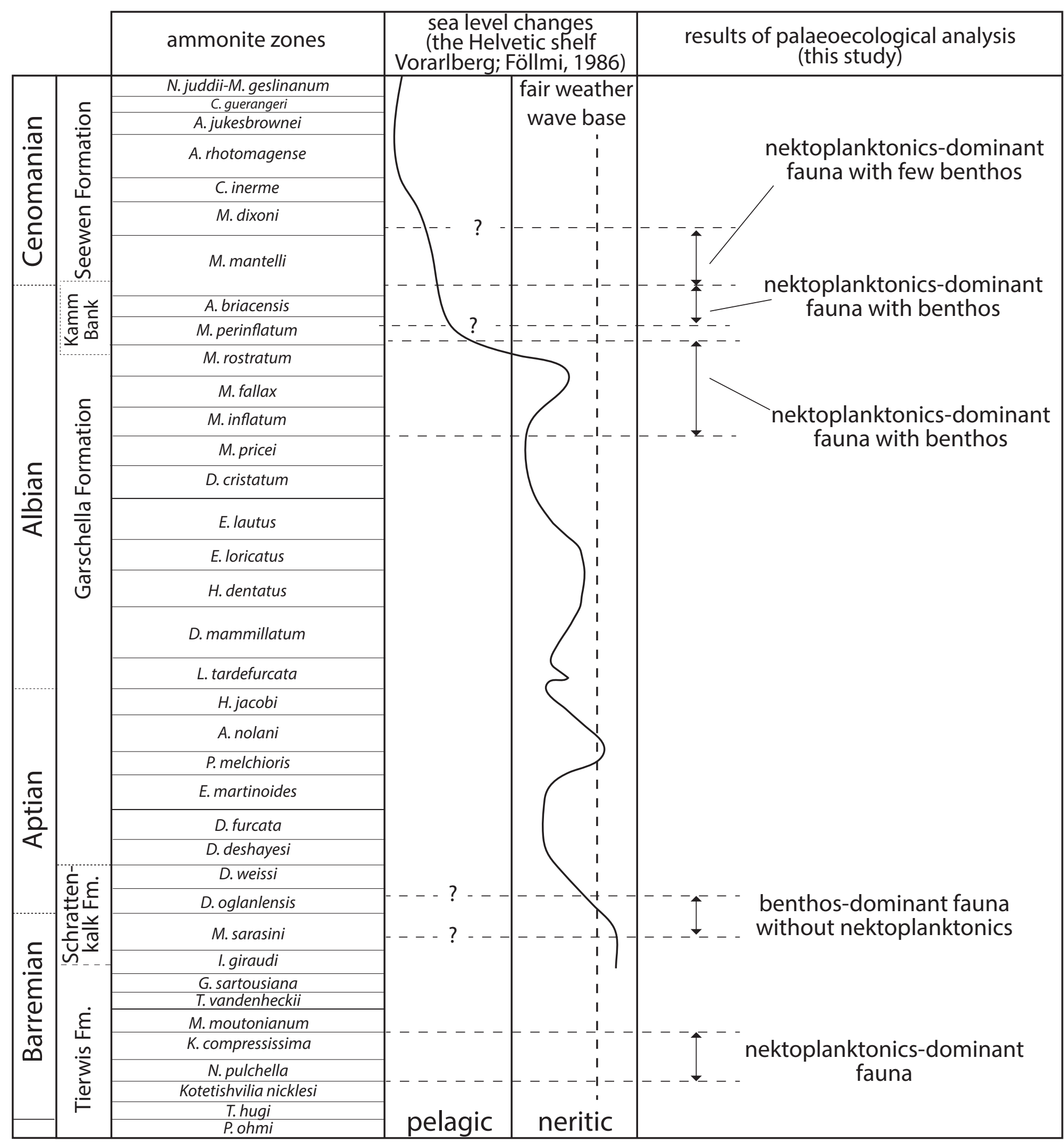



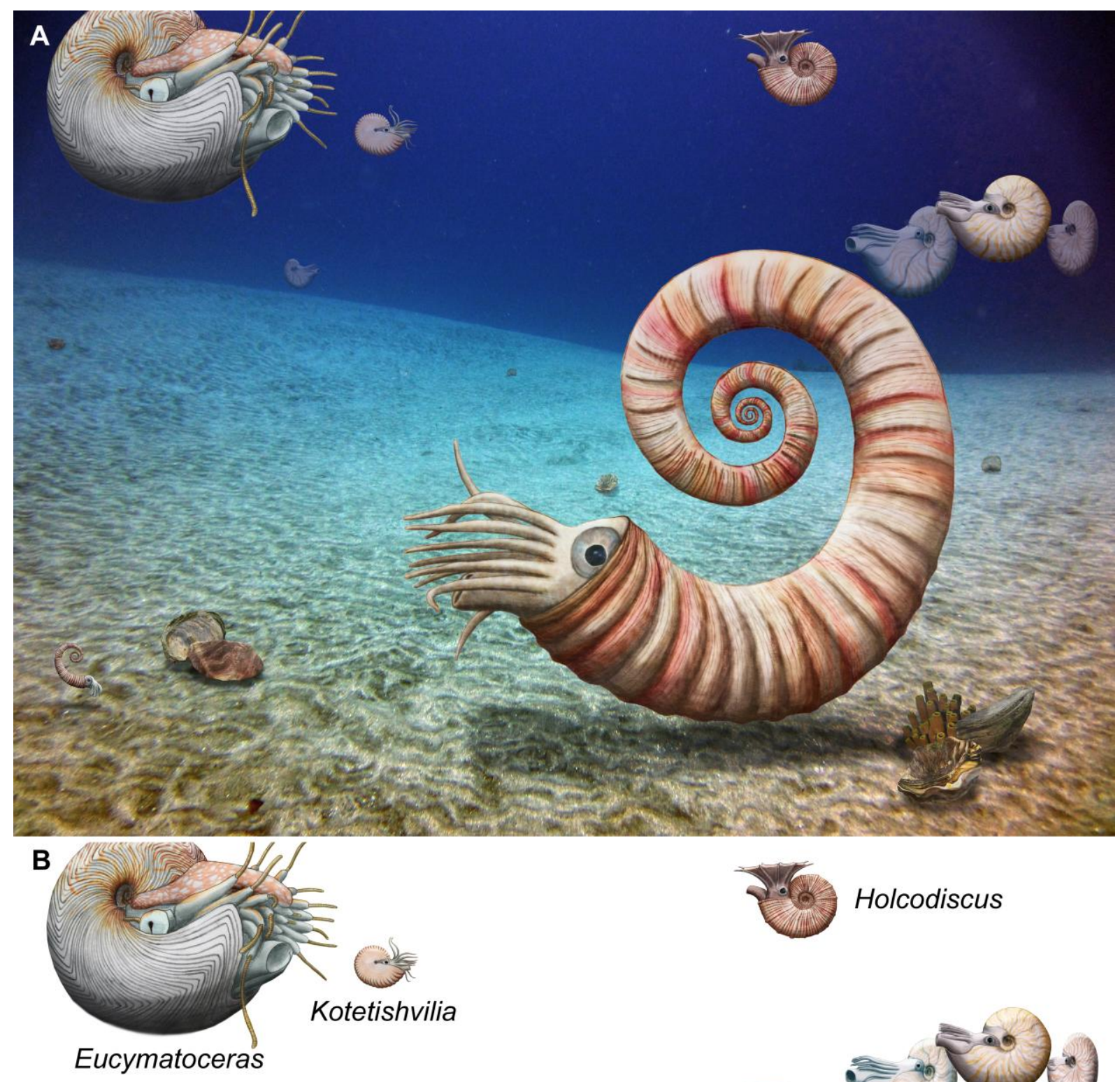

\section{Altman Member}
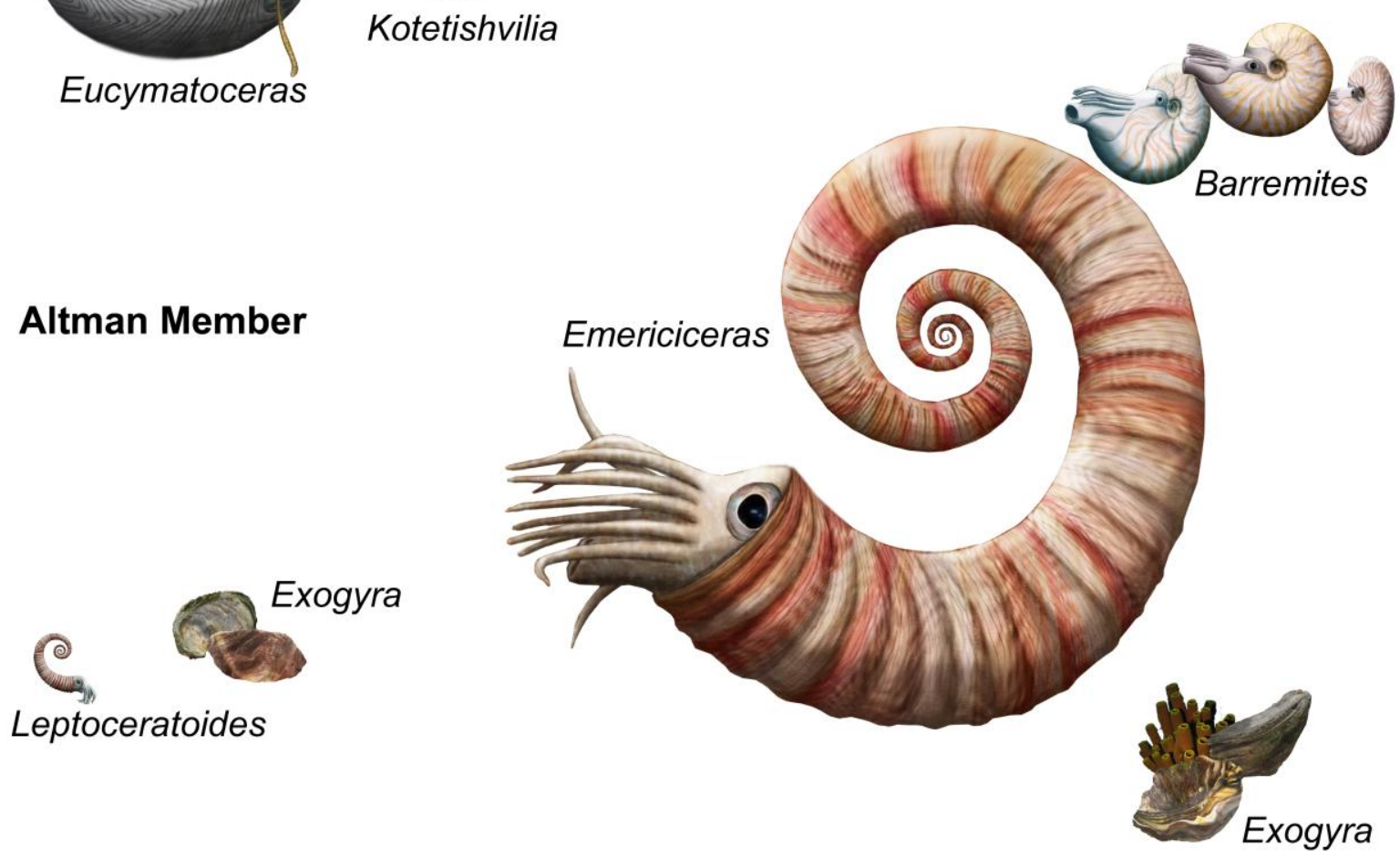

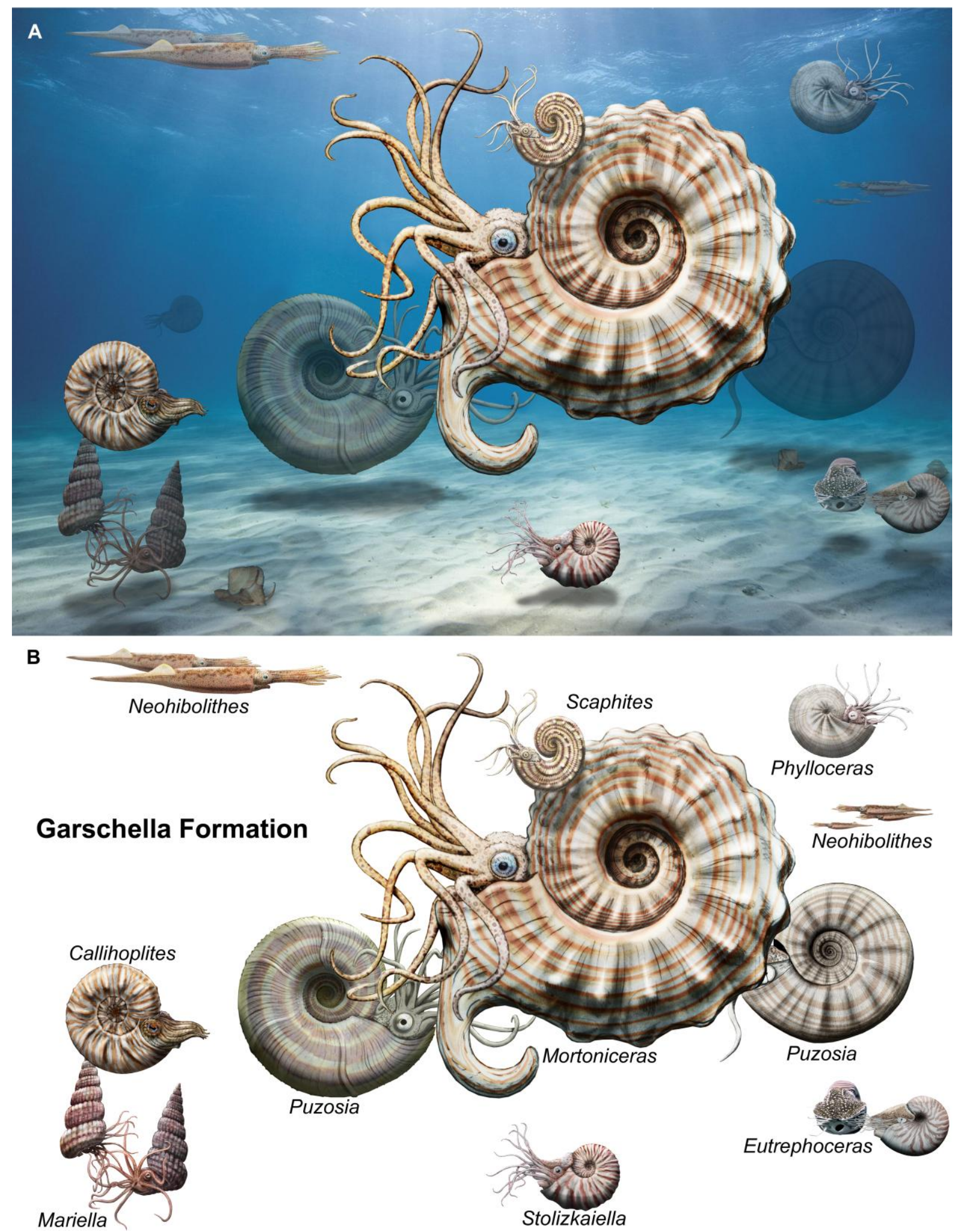


\begin{tabular}{|c|c|}
\hline Ecologic category & Examples \\
\hline \multicolumn{2}{|l|}{ Tiering } \\
\hline 1. Pelagic & ammonoids, belemnoids, fish, nautilids \\
\hline 2. Erect & crinoids, corals, sponges \\
\hline 3. Surficial & echinoids, brachiopods, gastropods \\
\hline 4. Semi-infaunal & „normal“ bivalves, rudist bivalves, scaphopods \\
\hline 5. Shallow infaunal & many clams \\
\hline 6. Deep infaunal & the clam Panope \\
\hline \multicolumn{2}{|l|}{ Motility Level } \\
\hline 1. Freely, fast & ammonoids, belemnoids, fish, some arthropods \\
\hline 2. Freely, slow & gastropods, echinoids, nautilids \\
\hline 3. Facultative, unattached & many clams, polychaetes: Sedentaria \\
\hline 4. Facultative, attached & corals, mussels \\
\hline 5. Non-motile, unattached & reclining brachiopods, scaphopods \\
\hline 6. Non-motile, attached & $\begin{array}{l}\text { boring bivalves, rudist bivalves, pedunculated } \\
\text { brachiopods, sponges }\end{array}$ \\
\hline \multicolumn{2}{|l|}{ Feeding Mechanism } \\
\hline 1. Suspension & $\begin{array}{l}\text { boring bivalves, brachiopods, bryozoans, corals, rudists, } \\
\text { scaphopods, sponges }\end{array}$ \\
\hline 2. Surface deposit & tellinid bivalves, polychaetes \\
\hline 3. Mining & nuculid bivalves \\
\hline 4. Grazing & echinoids, gastropods \\
\hline 5. Predatory & ammonoids, belemnoids, nautilids, fish \\
\hline 6. Other & \\
\hline
\end{tabular}




\begin{tabular}{|c|c|c|c|c|c|c|c|c|c|c|c|c|}
\hline & \multirow{2}{*}{$\begin{array}{l}\text { lower Barremian } \\
\text { (Altmann Mb.) }\end{array}$} & \multicolumn{8}{|c|}{ upper Barremian-lower Aptian (Schrattenkalk Formation) } & \multirow{2}{*}{$\begin{array}{l}\text { uppermost Albian } \\
\text { (Garschella Fm.) }\end{array}$} & \multirow{2}{*}{$\begin{array}{l}\text { uppermost Alb.- } \\
\text { lowermost Cnm. } \\
\text { (Kamm Bank) }\end{array}$} & \multirow{2}{*}{$\begin{array}{l}\text { lowermost } \\
\text { Cnm. } \\
\text { (Seewen Fm.) }\end{array}$} \\
\hline & & S1 & $\mathrm{S} 2$ & S3 & S4 & S5 & S6 & S7 & S8 & & & \\
\hline ammonites & 96 & & & & & & & & & 129 & 143 & 54 \\
\hline belemnites & 6 & & & & & & & & & & 2 & 37 \\
\hline fish & & & & & & & & & & 3 & 3 & 3 \\
\hline nautilids & 8 & & & & & & & & & 4 & 16 & \\
\hline bivalves & 17 & 76 & & & 275 & & 2 & & & 61 & 30 & 2 \\
\hline $\begin{array}{l}\text { boring } \\
\text { bivalves }\end{array}$ & & 2 & & & & 7 & 29 & & & & & \\
\hline $\begin{array}{l}\text { bivalves } \\
\text { (rudists) }\end{array}$ & & & 200 & 200 & & 56 & 30 & & 80 & & & \\
\hline $\begin{array}{l}\text { bivlaves } \\
\text { (oysters) }\end{array}$ & & & & & & & 2 & & & & & \\
\hline gastropods & 1 & 3 & 7 & 10 & 26 & & 1 & & & 31 & 23 & \\
\hline $\begin{array}{l}\text { corals } \\
\text { algaes }\end{array}$ & & 5 & & & 1 & 33 & 2 & & & 12 & 1 & \\
\hline brachiopods & 13 & & & & & & 1 & & & 6 & 12 & \\
\hline echinoids & 6 & & & & & & & 45 & & 4 & & 1 \\
\hline sponges & 7 & & & & & & & & & & & \\
\hline polychaete & 1 & & & & & & & & & & & \\
\hline decapod & & & & & & & & & & 1 & & \\
\hline scaphopoda & & & & & & & & & & 1 & & \\
\hline total & 156 & 86 & 207 & 210 & 302 & 96 & 67 & 45 & 80 & 251 & 240 & 98 \\
\hline
\end{tabular}

